Prepared in cooperation with the Colorado Division of Reclamation, Mining, and Safety

\title{
Review and Interpretation of Previous Work and New Data on the Hydrogeology of the Schwartzwalder Uranium Mine and Vicinity, Jefferson County, Colorado
}

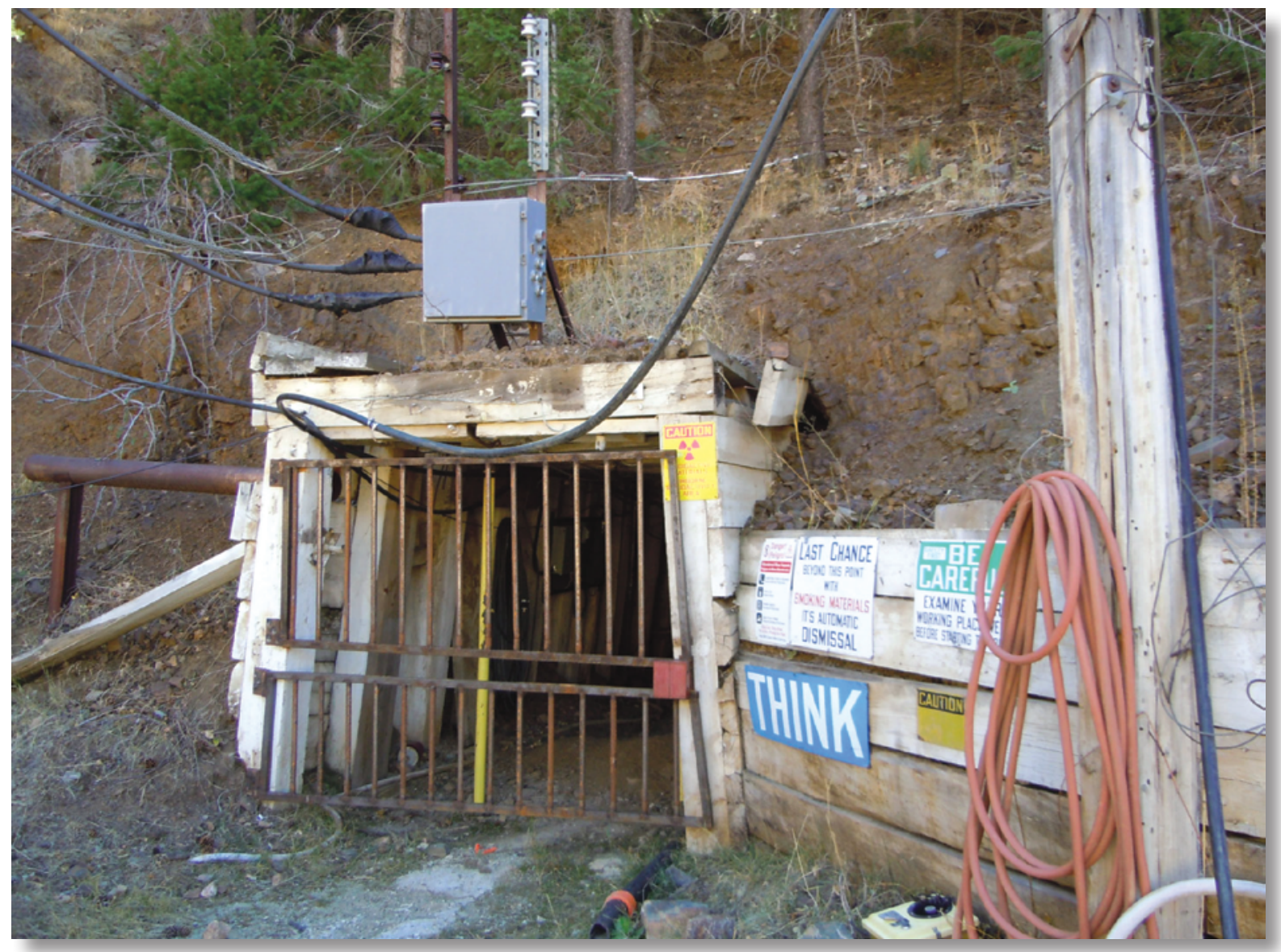

Open-File Report 2011-1092 


\section{Review and Interpretation of Previous Work and New Data on the Hydrogeology of the Schwartzwalder Uranium Mine and Vicinity, Jefferson County, Colorado}

By Jonathan Saul Caine, Raymond H. Johnson, and Emily C. Wild

Prepared in cooperation with the Colorado Division of Reclamation, Mining, and Safety

Open-File Report 2011-1092 


\title{
U.S. Department of the Interior \\ KEN SALAZAR, Secretary \\ U.S. Geological Survey \\ Marcia K. McNutt, Director
}

\section{U.S. Geological Survey, Reston, Virginia: 2011}

\author{
For more information on the USGS — the Federal source for science about the Earth, its natural and living resources, \\ natural hazards, and the environment, visit http://www.usgs.gov or call 1-888-ASK-USGS \\ For an overview of USGS information products, including maps, imagery, and publications, \\ visit http://www.usgs.gov/pubprod \\ To order this and other USGS information products, visit http://store.usgs.gov
}

Any use of trade, product, or firm names is for descriptive purposes only and does not imply endorsement by the U.S. Government.

Although this report is in the public domain, permission must be secured from the individual copyright owners to reproduce any copyrighted materials contained within this report.

Suggested citation:

Caine, J.S., Johnson, R.H., and Wild, E.C., 2011, Review and interpretation of previous work and new data on the hydrogeology of the Schwartzwalder Uranium Mine and vicinity, Jefferson County, Colorado: U.S. Geological Survey Open-File Report 2011-1092, 55 p. 


\section{Contents}

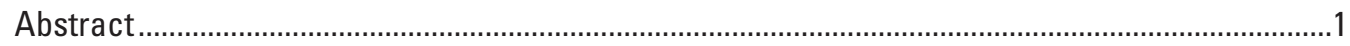

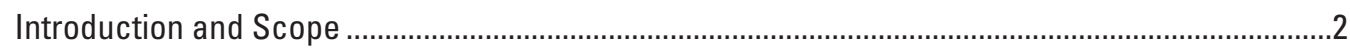

Overview of Geology and Controls on Groundwater ......................................................................4

Mine History and the Mine Site .............................................................................................................

General Comments on Wyman and Effner, 2007 ...........................................................................12

Specific, Section by Section Comments on Wyman and Effner, 2007..............................................13

Recent U.S. Geological Survey Analyses of Aqueous Geochemistry at the Schwartzwalder Mine Site ...............................................................................................22

Critical Questions Regarding the Hydrogeology of the Schwartzwalder Mine and the Source, Transport, and Fate of Dissolved Uranium .....................................................30

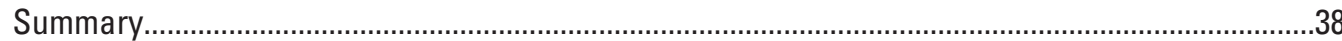

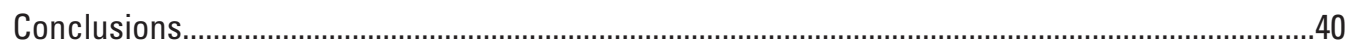

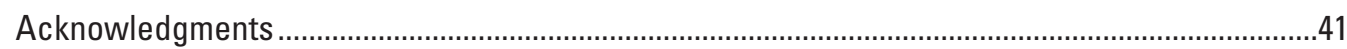

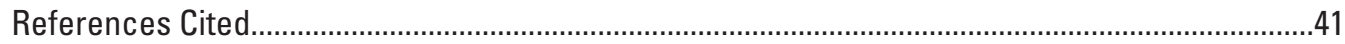

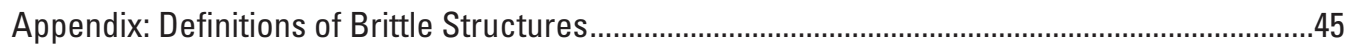

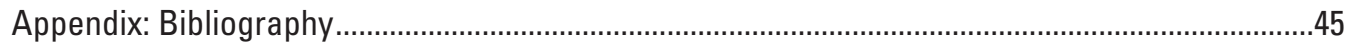

\section{Figures}

A. Map of Colorado showing major physiographic provinces, the Colorado Mineral Belt, and the location of the Schwartzwalder Mine ...............................3

B. Geologic map of the Schwartzwalder Mine showing key features relevant to hydrogeology ............................................................................................

C. Outcrop photos from the Schwartzwalder Mine site ......................................................9

D. Lower hemisphere, equal area projections .......................................................................11

E. Aerial photograph showing the Schwartzwalder Mine site .............................................11

F. Schwartzwalder Mine workings and geologic cross section ........................................12

G. Schematic cross section of the Schwartzwalder Mine....................................................14

H. Schematic location map of the Schwartzwalder Mine site footprint and surface and groundwater sampling sites ...............................................................29

I. Selected geochemical data from six U.S. Geological Survey water samples ................29

J. Uranium isotopic activity ratios (AR) of ${ }^{234} \mathrm{U}$ and ${ }^{238} \mathrm{U}$ from six U.S. Geological Survey water samples E.....

K. Selected geochemical results from six U.S. Geological Survey water samples collected on November 19, 2010 of common major lithophile and radiogenic elements. (1) Site specific concentrations. The scale is linear and expanded from $100,000 \mu \mathrm{g} / \mathrm{L}$ to $600,000 \mu \mathrm{g} / \mathrm{L}$. (2) Box plot concentrations 
L. Selected geochemical results from six U.S. Geological Survey water samples collected on November 19, 2010 of elements commonly found in water associated with epithermal, polymetallic hydrothermal alteration.

(1) Site specific concentrations. The scale from 0 to $100 \mu \mathrm{g} / \mathrm{L}$ is linear. Above $100 \mu \mathrm{g} / \mathrm{L}$ the scale is expanded and logarithmic. (2) Box plots concentrations

M. Aerial photograph draped on a 3-m resolution digital elevation model and tilted to show topography and the region of permissible groundwater flow down-gradient from the mine workings.

N. Fault zone, fracture, and fault vein conceptual models showing physical components and potential hydrological influences.

\section{Tables}

A. Expanded estimates of inflow to mine

B. Recent mine pool elevation data and projections of water levels from measured infill rates

C. Schwartzwalder Mine site aqueous elemental chemistry of surface and groundwater

D. Schwartzwalder Mine topographic and hydraulic gradient data and average linear velocity estimates 


\section{Conversion Factors}

Inch/Pound SI

\begin{tabular}{|c|c|c|}
\hline Multiply & By & To obtain \\
\hline \multicolumn{3}{|c|}{ Length } \\
\hline inch (in.) & 2.54 & centimeter $(\mathrm{cm})$ \\
\hline foot $(\mathrm{ft})$ & 0.3048 & meter $(\mathrm{m})$ \\
\hline mile (mi) & 1.609 & kilometer $(\mathrm{km})$ \\
\hline \multicolumn{3}{|c|}{ Area } \\
\hline acre & 4,047 & square meter $\left(\mathrm{m}^{2}\right)$ \\
\hline acre & 0.4047 & hectare (ha) \\
\hline acre & 0.004047 & square kilometer $\left(\mathrm{km}^{2}\right)$ \\
\hline square mile $\left(\mathrm{mi}^{2}\right)$ & 2.590 & square kilometer $\left(\mathrm{km}^{2}\right)$ \\
\hline \multicolumn{3}{|c|}{ Volume } \\
\hline quart (qt) & 0.9464 & liter $(\mathrm{L})$ \\
\hline gallon (gal) & 3.785 & liter (L) \\
\hline gallon (gal) & 0.003785 & cubic meter $\left(\mathrm{m}^{3}\right)$ \\
\hline cubic yard $\left(\mathrm{yd}^{3}\right)$ & 0.7646 & cubic meter $\left(\mathrm{m}^{3}\right)$ \\
\hline \multicolumn{3}{|c|}{ Flow rate } \\
\hline cubic foot per second $\left(\mathrm{ft}^{3} / \mathrm{s}\right)$ & 0.02832 & cubic meter per second $\left(\mathrm{m}^{3} / \mathrm{s}\right)$ \\
\hline gallon per minute (gal/min) & 0.06309 & liter per second $(\mathrm{L} / \mathrm{s})$ \\
\hline \multicolumn{3}{|c|}{ Hydraulic conductivity } \\
\hline foot per second (ft/s) & 0.3048 & meter per second $(\mathrm{m} / \mathrm{s})$ \\
\hline foot per day $(\mathrm{ft} / \mathrm{d})$ & 0.000353 & centimeter per second $(\mathrm{cm} / \mathrm{s})$ \\
\hline
\end{tabular}

Temperature in degrees Celsius $\left({ }^{\circ} \mathrm{C}\right)$ may be converted to degrees Fahrenheit $\left({ }^{\circ} \mathrm{F}\right)$ as follows:

${ }^{\circ} \mathrm{F}=\left(1.8 \mathrm{x}^{\circ} \mathrm{C}\right)+32$.

Horizontal coordinate information is referenced to the World Geodetic System of 1984 (WGS 84).

Except where noted, vertical coordinate information is referenced to the Earth Gravitational Model of 1996 (EGM 96).

Elevation, as used in this report, refers to distance above the vertical datum.

Concentrations of chemical constituents in water are given either in milligrams per liter $(\mathrm{mg} / \mathrm{L})$, micrograms per liter $(\mu \mathrm{g} / \mathrm{L})$, or as the activity of radionuclides in picocuries per liter ( $\mathrm{pCi} / \mathrm{L})$.

Specific conductance is given in microsiemens per centimeter at 25 degrees Celsius $(\mu \mathrm{S} / \mathrm{cm}$ at $\left.25^{\circ} \mathrm{C}\right)$.

Free air radioactivity measured near the ground surface with a handheld scintillation counter is given in microroentgens per hour (mR/hr).

Reduction potential (Eh) is given in millivolts.

Additional conversion factors are provided for units in common use but not necessarily used in this report. 



\title{
Review and Interpretation of Previous Work and New Data on the Hydrogeology of the Schwartzwalder Uranium Mine and Vicinity, Jefferson County, Colorado
}

\author{
By Jonathan Saul Caine, Raymond H. Johnson, and Emily C. Wild
}

\section{Abstract}

The Schwartzwalder deposit is the largest known vein type uranium deposit in the United States. Located about eight miles northwest of Golden, Colorado it occurs in Proterozoic metamorphic rocks and was formed by hydrothermal fluid flow, mineralization, and deformation during the Laramide Orogeny. A complex brittle fault zone hosts the deposit comprising locally brecciated carbonate, oxide, and sulfide minerals. Mining of pitchblende, the primary ore mineral, began in 1953 and an extensive network of underground workings was developed. Mine dewatering, treatment of the effluent and its discharge into the adjacent Ralston Creek was done under State permit from about 1990 through about 2008. Mining and dewatering ceased in 2000 and natural groundwater rebound has filled the mine workings to a current elevation that is above Ralston Creek but that is still below the lowest ground level adit. Water in the "mine pool" has concentrations of dissolved uranium in excess of 1,000 times the U.S. Environmental Protection Agency drinkingwater standard of $30 \mu \mathrm{g} / \mathrm{L}$. Other dissolved constituents such as molybdenum, radium, and sulfate are also present in anomalously high concentrations.

Ralston Creek flows in a narrow valley containing Quaternary alluvium predominantly derived from weathering of crystalline bedrock including local mineralized rock. Just upstream of the mine site, two capped and unsaturated waste rock piles with high radioactivity sit on an alluvial terrace. As Ralston Creek flows past the mine site, a host of dissolved metal concentrations increase. Ralston Creek eventually discharges into Ralston Reservoir about 2.5 miles downstream. Because of highly elevated uranium concentrations, the State of Colorado issued an enforcement action against the mine permit holder requiring renewed collection and treatment of alluvial groundwater.

As part of planned mine reclamation, abundant data were collected and compiled into a report by Wyman and Effner (2007), which was to be used as a basis for eventual mine site closure. In 2010 the U.S. Geological Survey was asked by the State of Colorado to provide an objective and independent review of the Wyman and Effner (2007) report and to identify gaps in knowledge regarding the hydrogeology of the mine site.

Key findings from the U.S. Geological Survey assessment include geological structural analysis indicating that although the primary uranium-hosting fault likely does not cross under Ralston Creek, many complex subsidiary faults do cross under Ralston Creek. It is unknown if any of these faults act as conduits for mine pool water to enter Ralston Creek. Reported bedrock permeabilities are low, but local hydraulic gradients are sufficient to potentially drive groundwater flow from the mine pool to the creek. Estimated average linear velocities for the full range of reported hydraulic conductivities indicate groundwater transit times from the mine pool to the creek on the order of a few months to about 3,800 years or 11 to 65 years using mean reported input values. These estimates do not account for geochemical reactions along any given flow path that may differentially enhance or retard movement of individual dissolved constituents. New reconnaissance data including ${ }^{34} \mathrm{~S}$ isotope and ${ }^{234} \mathrm{U} /{ }^{238} \mathrm{U}$ isotopic activity ratios (AR) show potentially distinctive signatures for the mine pool compared to local groundwater and Ralston Creek water above the mine site.

Although the mine pool may be near an equilibrium elevation, evidence for groundwater recharge transients indicates inflow to the workings that are greater than outflow. There is not enough hydraulic head data adjacent to the mine workings to adequately constrain a final equilibrium elevation or to predict how several wet years in succession might affect variations in mine pool elevation. Although ground level adits are sealed with bulkheads, if the mine pool elevation were to rise slightly to the elevation of or above these adits, there is additional potential for seepage into the environment. The mine workings, mine pool water, the mineralized fault zone, and parts of the alluvial aquifer contaminated by mine waste are all potential sources of dissolved metals to Ralston Creek. The waste rock piles are not a major contaminant source at this time based on data in Wyman and Effner (2007) and new U.S. Geological Survey data. However, questions regarding the long-term integrity of the cap rock seal, possible 
leaching processes between the unsaturated and saturated zone, groundwater flow in the alluvial aquifer and a 100 -yearplus flood make the waste rock piles a potential source in the future.

Recent geochemical data from Ralston Creek shows dissolved uranium concentrations that remain above drinkingwater standards in spite of treatment operations. The mine pool water is now hydraulically above the creek, and the pathway(s) for mine pool water flowing into the alluvial aquifer and Ralston Creek through the bedrock should be investigated further.

Established monitoring wells at the mine site are not adequate to characterize local hydraulic head and to contrast the geochemistry of bedrock and alluvial groundwater because many of them are screened in both the bedrock and alluvium. The bedrock is particularly underrepresented in existing wells. This report suggests the drilling and completion of appropriately sited and nested bedrock and alluvial well pairs. These wells should be sampled in conjunction with a series of stream tracer dilution studies in Ralston Creek with the sumps operational as well as shut down. An expanded program of water sampling could include high precision uranium and sulfur isotope analyses and other analyses of potentially diagnostic trace elements and their ratios. This approach may permit the identification of mine pool and(or) other mixed contaminated water entering Ralston Creek. It will be critical to determine if the hydraulic heads in the bedrock wells are higher than in the alluvial wells. Although Ralston Creek delivers a relatively small proportion of water flowing to Ralston Reservoir, continued monitoring of the mine pool elevation and dissolved uranium concentrations in all water samples is essential.

\section{Introduction and Scope}

The Schwartzwalder Uranium Mine, located approximately 8 miles northwest of Golden, Colorado comprises an underground network of workings in faulted and fractured Proterozoic crystalline rocks and a variety of materials at the surface associated with the mining operations (Figure A). The mine was accessed by a number of adits just above and within about $300 \mathrm{ft}$ of Ralston Creek. Ralston Creek contributes a small proportion of flow to the Ralston Reservoir approximately 2.5 miles downstream from the mine site (Figure A). (Note that scientific literature commonly uses the International System of Units, however Inch/Pound units of measure are primarily used in this report as these were the units reported in data from the Schwartzwalder Mine.) The reservoir is primarily filled with water from a transmountain diversion tunnel and is one of several sources of drinking water for the city of Denver and its western suburban areas. During the period from 1994 through 2010 Ralston Creek contributed an average of 6.6 percent (median of 5.7 percent) total annual inflow to Ralston reservoir with a maximum of 26.7 percent in 1995 and a minimum of 0.3 percent in 2002 (Denver Water, written commun., 2011).
Throughout the history of mining at the Schwartzwalder Mine the workings were dewatered to facilitate mining operations. The primary mine operator, the Cotter Corporation, presently (2010) a subsidiary of General Atomics of San Diego, Calif., has conducted mining and water treatment under permits issued by the State of Colorado allowing for discharge of treated mine water effluent to Ralston Creek. Several state agencies as well as Cotter Corporation have extensively monitored water quality in Ralston Creek and discharged effluent. A previous study of water quality in surface water of the 1:100,000 Denver West Quadrangle identified anomalously high dissolved uranium and radium in Ralston Creek below the mine site (Zielinski and others, 2008).

In May 2010 the Colorado Division of Reclamation, Mining, and Safety (DRMS) - the regulatory agency in charge of oversight, routine, and independent monitoring of water quality in Ralston Creek associated with the Schwartzwalder Mine-pursued an Enforcement Action against the Cotter Corporation. The Enforcement Action was because of measured concentrations of total dissolved uranium in Ralston Creek associated with the mine site that are approximately 10 times greater in the creek and approximately 1,000 times greater in the mine groundwater than the U.S. Environmental Protection Agency (USEPA) drinking-water standard of 30 micrograms per liter $(\mu \mathrm{g} / \mathrm{L})$ (parts per billion) total dissolved uranium [Wyman and Effner, 2007; Colorado Division of Reclamation, Mining, and Safety, 2010; U.S. Environmental Protection Agency 40 CFR § 141.66 (e)]. The Enforcement Action requires the Cotter Corporation to initiate immediate corrective actions to reduce the concentrations of uranium and other constituents to established standards in Ralston Creek at the mine site (Colorado Division of Reclamation, Mining, and Safety, 2010). The Enforcement Action also involves reassessment of the adequacy of several versions of an Environmental Protection Plan submitted to DRMS for mine site reclamation, maintenance of solute concentrations in Ralston Creek at or below standards, and mine site closure.

In an effort to better understand the surface water and groundwater flow systems and their interactions, the sources and fate of uranium and other heavy metal contamination in Ralston Creek, the Colorado DRMS asked the U.S. Geological Survey to review and evaluate the adequacy of the current state of knowledge and data pertaining to the hydrogeology at the Schwartzwalder Mine and surrounding area potentially affected by the mine. The primary subject of this review is a report by Wyman and Effner (2007). (Also see http://mining.State.CO.US for other reports and information related to the Schwartzwalder Mine). The Wyman and Effner (2007) report contains the most current and extensive hydrological and aqueous geochemical data for the mine site and forms the scientific basis for the subsequent Environmental Protection Plans.

The faulted, fractured, and veined bedrock near the Schwartzwalder Mine imparts hydraulic and geochemical heterogeneity. These geological heterogeneities make understanding of the fate of groundwater flow and solute 

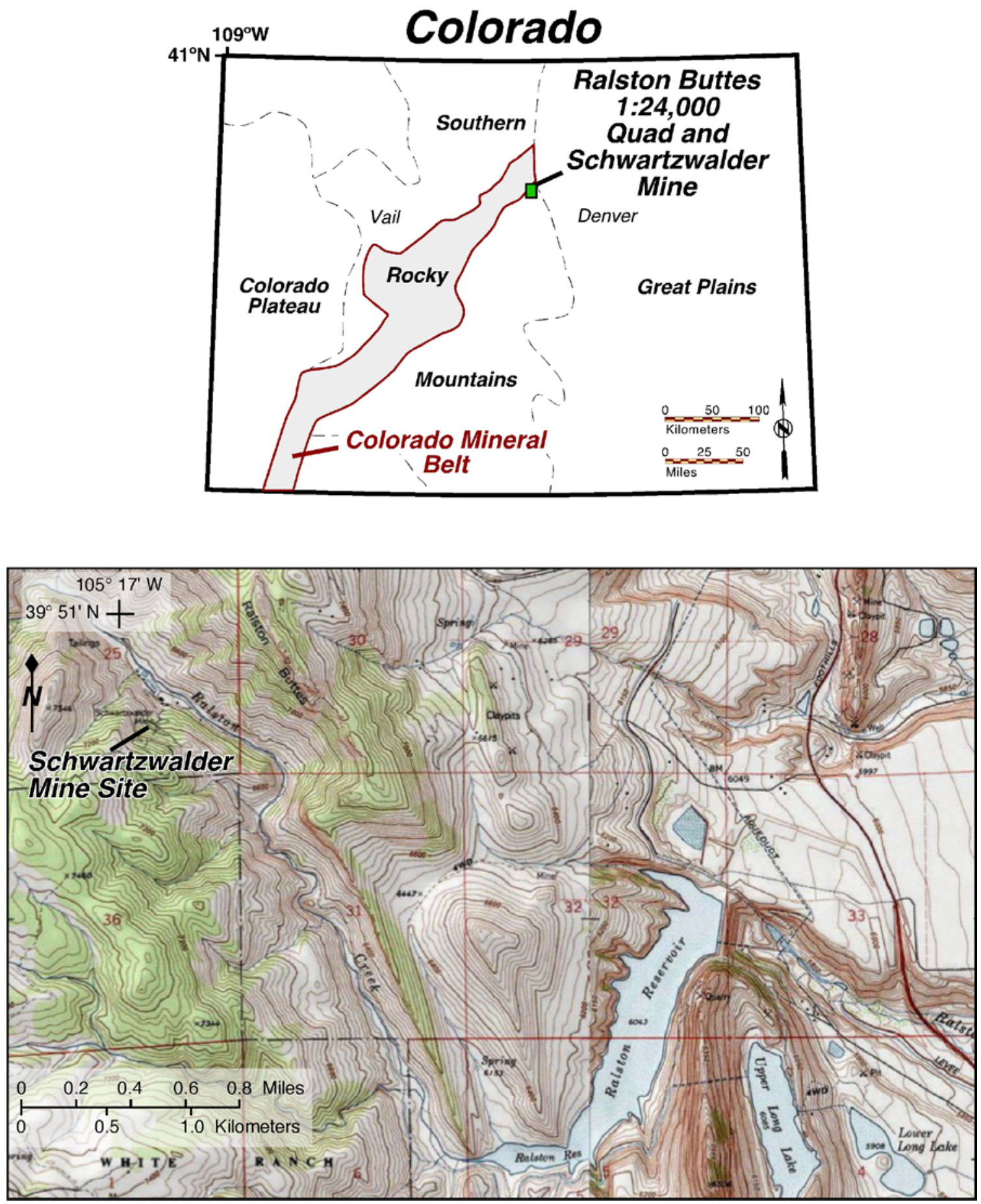

Figure A. Map of Colorado showing major physiographic provinces, the Colorado Mineral Belt, and the location of the Schwartzwalder Mine. The lower topographic map is from the U.S. Geological Survey, $30 \mathrm{x}$ 60 minute, Denver West quadrangle. 
transport near the mine site particularly challenging. The purpose of this report is to provide independent and objective evaluation and review of all available material; to verify data quality, calculations made, and adequacy of conceptual and predictive models in the Wyman and Effner (2007) report; and to report on limited new data that have been collected and analyzed as an independent check on existing research. The structure of this report includes: (1) brief characteristics of the geology and physical setting as it pertains to the hydrogeology; (2) history of mining and water resources at the mine site; (3) general and specific comments on the Wyman and Effner (2007) report; (4) descriptions of new data collected, the methods used, analytical results and interpretations; (5) and concluding remarks on the adequacy of existing knowledge with suggestions for addressing gaps in information as requested by the Colorado DRMS. In addition to references cited in this report, a complete bibliography of source information is provided. The Wyman and Effner (2007) report uses sequentially numbered figures and tables; in this report sequentially lettered figures and tables are used to help differentiate the two reports.

\section{Overview of Geology and Controls on Groundwater}

The Schwartzwalder uranium deposit is the largest vein-type uranium deposit in the United States (Adams and others, 1953; Sims and others, 1964; Sheridan and others, 1967; Zielinski and others, 2008). The deposit is associated with Laramide age (about $70 \mathrm{Ma}$ ) hydrothermal fluid flow, faulting, fracturing, and polymetallic vein formation (Wallace and Karlson, 1985; Ludwig and others, 1985). It is hosted in tightly folded Paleoproterozoic quartzofeldspathic and calcsilicate metasedimentary and metavolcanic rock "units" common in the central southern Rocky Mountains (Figures A and B). A complex network of Paleooroterozoic and(or) Mesoproterozoic pegmatite dikes also intruded these rocks.

The Schwartzwalder Mine site is located in a narrow, approximately 330 -foot wide, and steep valley incised by Ralston Creek into the eastern edge of the foothills of the Southern Rocky Mountains (Figure A). The creek channel is filled with locally and distally derived, coarse alluvial and colluvial sediments comprising a shallow aquifer (Qpp on Figure B; Sheridan and others, 1967).

The mineral deposit comprises a network of fault veins that host brittley deformed oxide, sulfide, and carbonate mineral assemblages. Fault veins are complex brittle structures that are characterized by elements of both veins (mineral filled fractures) and faults that accommodate shearing of rock, producing fault rocks such as clay-rich gouge (see Appendix and Caine and others, 2010 for a more complete description of fault veins and their permeability). Joint networks likely formed by tectonic and exhumation processes are pervasive in the near surface, at depth at the mine site, and the surrounding region. Together the various crystalline rock types, foliations, folds, dikes, faults, veins, and joints comprise a complex and heterogeneous bedrock aquifer host for the Schwartzwalder uranium deposit.

In the metamorphic rock "units" compositional layering is generally parallel to foliation. Each of the units has varying intergranular permeability $(k)$. There is a major upright and tight synform that plunges to the southwest (Figure B; Sheridan and others, 1967). As a result, the rock layering dips nearly vertical and has a diffuse but generally southwestnortheast strike (Figures $\mathrm{C}$ and D). The foliation appears to have had some effect on the development and orientation of subsequent structures such as joints (Wallace and Karlson, 1985) that may control anisotropy in groundwater flow.

The primary structure that hosts the Schwartzwalder uranium deposit is the Illinois fault zone. The Illinois fault zone and associated mineralization is localized in a relatively narrow "lithologic transition zone" composed of quartzite and garnet-biotite-gneiss between hornblende gneiss to the west and mica schists to the south (Wallace and Karlson, 1985). This zone was later referred to as "the Schwartz Trend" (for example, Norqist, 2001). However, hydrothermal mineralization and associated uranium ore minerals are primarily associated with the Illinois fault zone in the transition rocks and not with the "lithologic transition zone" itself. Hydrothermal minerals were deposited at Schwartzwalder in at least three stages and include adularia, ankerite-dolomite, calcite, pitchblende, hematite, coffinite, pyrite, chalcopyrite, unusual Fe-Mo-As sulfides, galena, sphalerite, and fluorite (Wallace and Whelan, 1986).

The Illinois fault zone strikes northwest with a curviplanar surface trace that dips steeply to the southwest (Sheridan and others, 1967). At the mine the fault zone trace shows a right jog striking north-northeast, dipping 75 to 60 degrees to the west-northwest (Wallace and Karlson, 1985). The mapped trace length of the fault zone is approximately 4,600 $\mathrm{ft}$ (Sheridan and others, 1967). Where the jog ends, the fault zone returns to its northwest strike and parallels Ralston Creek on its southwest side until it crosses the creek and merges with the east Rogers fault, a wide zone of distributed brittle deformation at this location, about 3,300 ft from the Schwartzwalder adits. Several smaller splays of the Illinois fault are shown on maps (Sheridan and others, 1967). These splays cross under Ralston Creek and the alluvial aquifer to the northeast a few hundred feet from the Steve and Pierce adits, among the primary access points to the mine workings. There are outcrops of hydrothermal fault veins that were mined from an adit directly to the northeast of the jog on the north side of the creek (the "North Portal" in Figure B2b). Beige hydrothermal alteration halos surround many of these fault veins and the vein cores are locally vuggy, suggesting that these fault veins have enhanced permeability compared to their host rock. The primary Illinois fault zone ranges in width from several inches to about $7 \mathrm{ft}$ (Wallace and Karlson, 1985). Wallace and Karlson (1985) also report apparently natural, $3 \mathrm{ft}$ wide "open watercourses" in the core of the Illinois fault zone that extend 


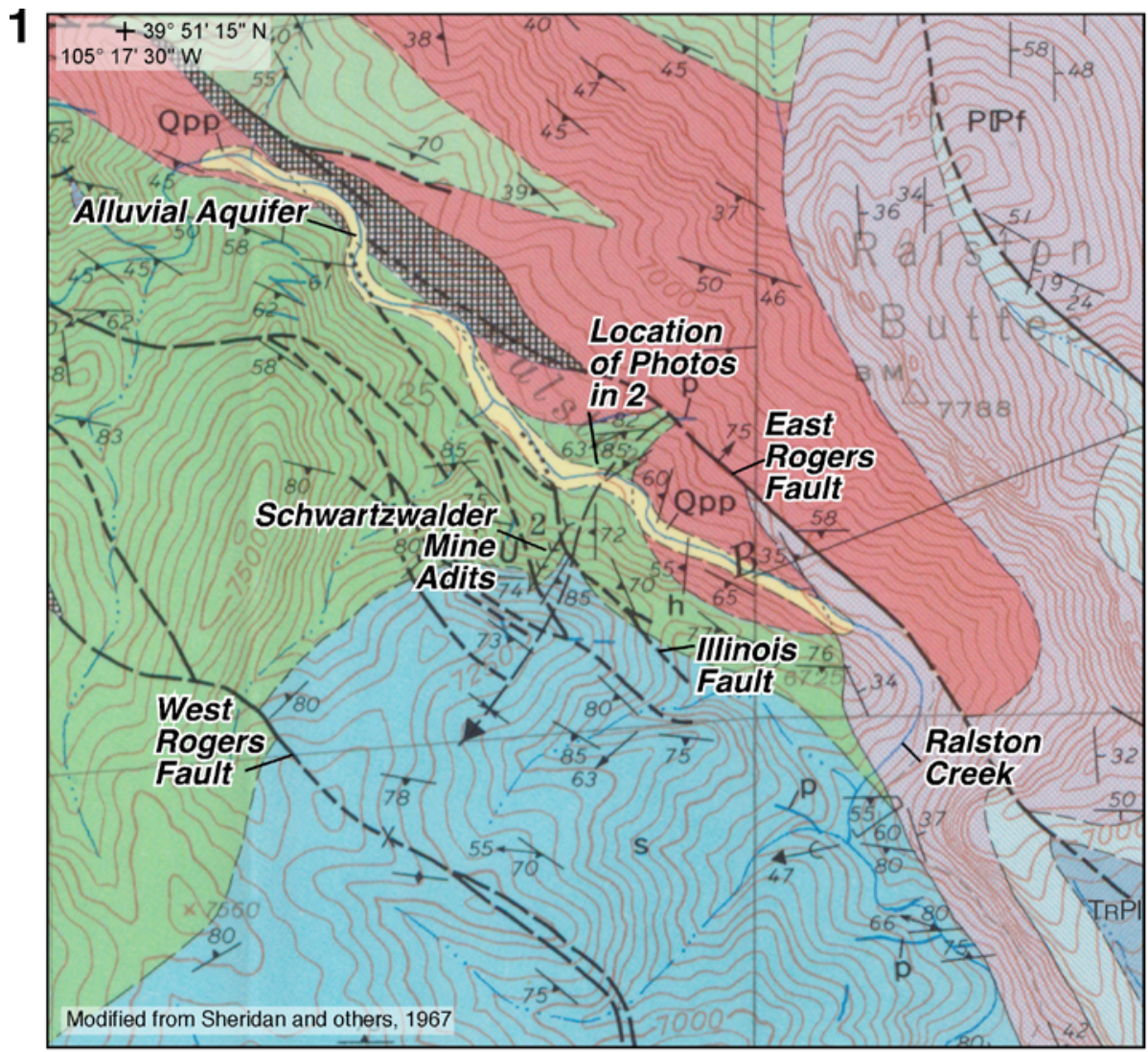

\section{EXPLANATION}

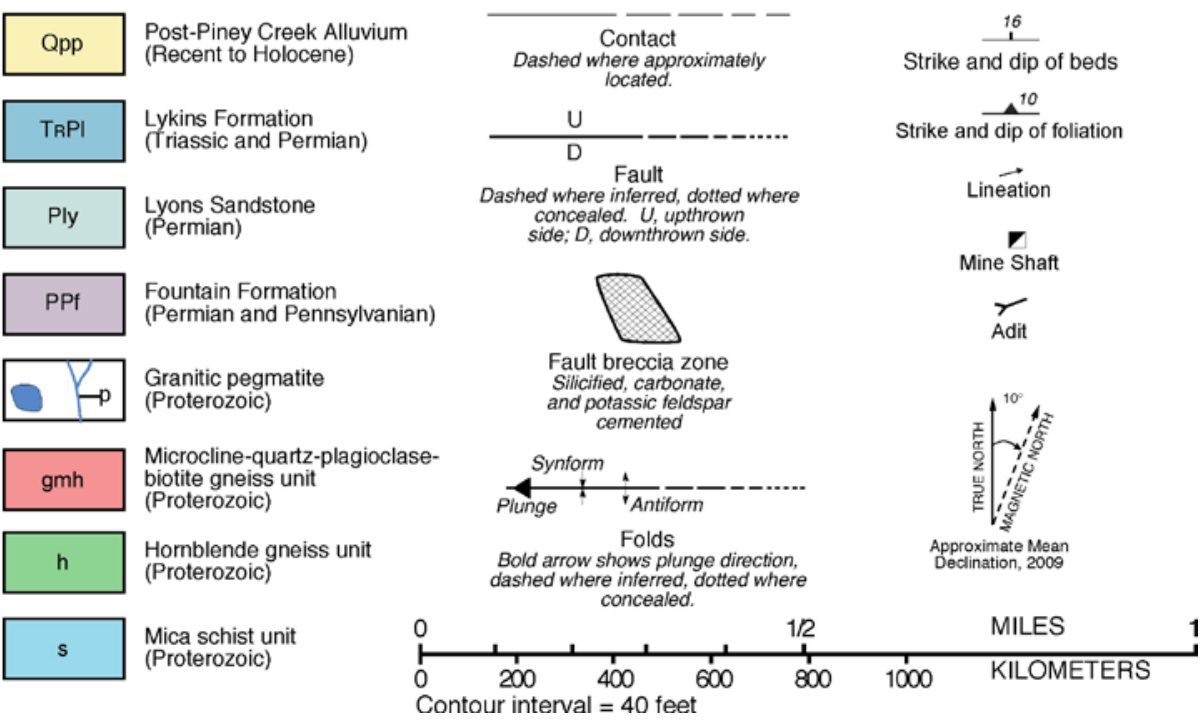

Figure B. (1) Geologic map of the Schwartzwalder Mine showing key features relevant to hydrogeology (modified from Sheridan and others, 1967). (2) Photographs of carbonate fault veins looking northeast from the Minnesota Level to the "North Portal" of the Schwartzwalder Mine: (a) Complex network of fault vein splays with orientations similar to those reported in Wallace and Karlson (1985); (b) Schematic trace map of the fault vein network in red; (c) Close-up view of a fault vein showing the carbonate primary vein adjacent to the compass with a beige hydrothermal alteration halo surrounding it. These structures may have higher bulk permeability than the surrounding less altered hornblendebiotite-quartz gneiss host rock. The location of these photographs is shown in 1 . 

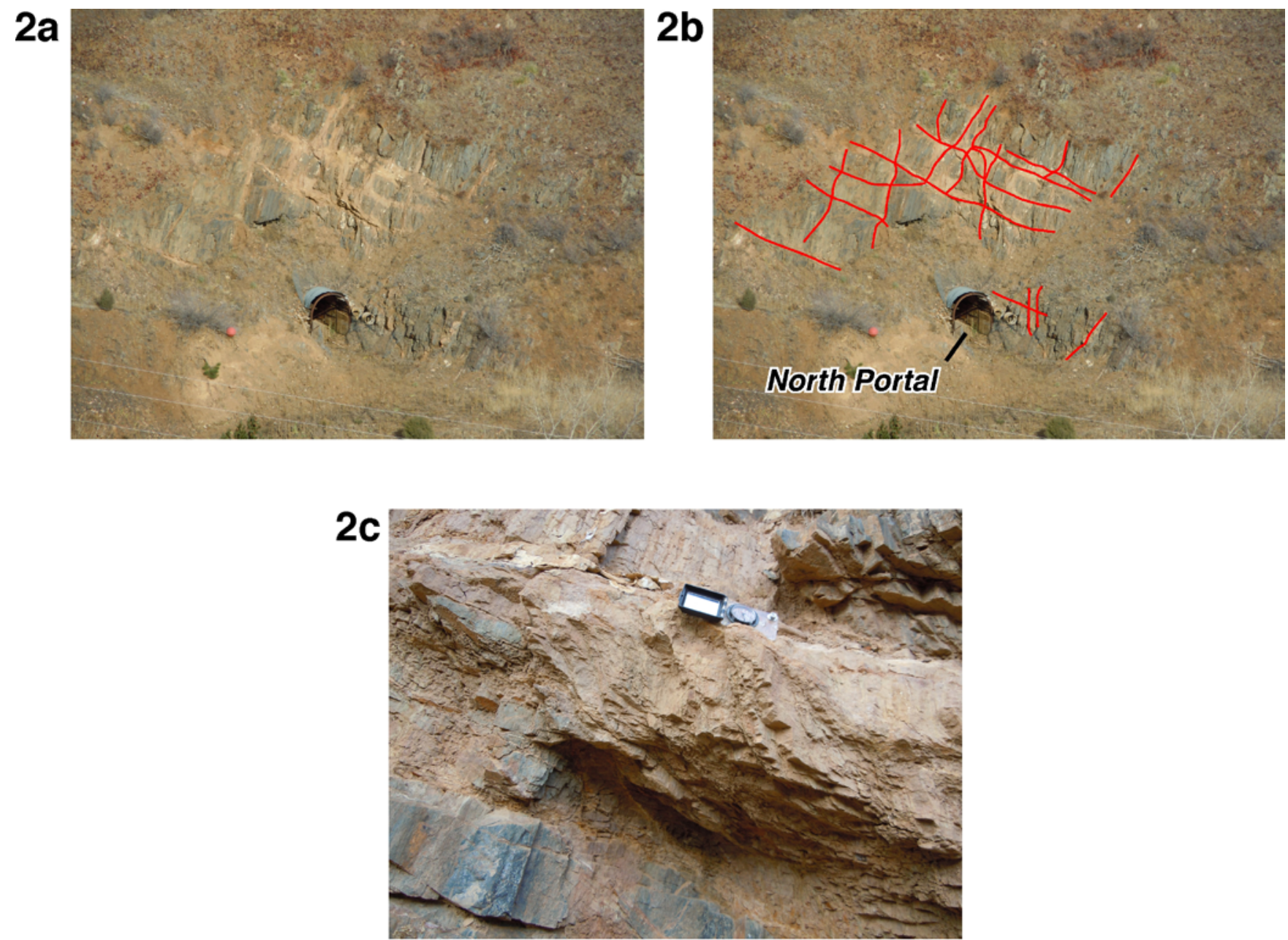

Figure B. (1) Geologic map of the Schwartzwalder Mine showing key features relevant to hydrogeology (modified from Sheridan and others, 1967). (2) Photographs of carbonate fault veins looking northeast from the Minnesota Level to the "North Portal" of the Schwartzwalder Mine: (a) Complex network of fault vein splays with orientations similar to those reported in Wallace and Karlson (1985); (b) Schematic trace map of the fault vein network in red; (c) Close-up view of a fault vein showing the carbonate primary vein adjacent to the compass with a beige hydrothermal alteration halo surrounding it. These structures may have higher bulk permeability than the surrounding less altered hornblende-biotite-quartz gneiss host rock. The location of these photographs is shown in 1.-Continued 
tens of vertical feet within the mine. The total width of the Illinois fault zone, including the primary fault segments and immediately surrounding splays, is on the order of several to 30 or more feet (for example, Figure B2.)

The Illinois fault zone is highly complex with pre- and post- ore segments comprising a composite structure with multiple splay fault veins, also known as tension fractures, horsetails, or flats. These splays primarily branch off to the west in the hanging wall with antithetic dips to the main fault zone and are the primary ore hosting structures (Wallace and Karlson, 1985). The fault vein splays are significant structures with lengths along dip of hundreds of feet. Splays are a few inches to more than $30 \mathrm{ft}$ wide with zones of fractured and brecciated rock in their cores. A prominent set of subparallel, open joints is also associated with many of the fault vein splays (Wallace and Karlson, 1985).

Motion in the Illinois fault zone may be related to the Rogers fault zone that has two primary segments (west and east) that bound the Illinois fault zone (Figure B). The west Rogers fault segment also hosts uranium mineralization and may be important in the kinematic history of this fault system (Wallace and Karlson, 1985). The three fault zones have complex and likely interrelated kinematic history. There are components of reverse, normal, and strike slip displacement on the order of several hundred feet, with at least $330 \mathrm{ft}$ of "normal" dip-slip displacement (Wallace and Karlson, 1985) accommodated by the Illinois fault zone. If there was a component of right-lateral motion on the Illinois during extension, dilation at the right stepping jog could have formed an extensive zone of opening with potential for localization of hydrothermal fluid flow and mineral deposition.

Extensional deformation associated with the Illinois fault zone is significant to the present-day hydrogeology. Extension commonly involves brecciation and the Schwartzwalder deposit is no exception. The internal structure of the Illinois fault zone and associated subsidiary structures include a complex and anastomosing core zone with highly brecciated hydrothermal vein mineral assemblages. These assemblages are variably cemented and locally open with vugs and mismatched fault surfaces that likely form the open watercourses described by Wallace and Karlson (1985). Many other minor faults provide slip surfaces that may be open or variably filled with clay-rich or other types of fault gouge (Appendix and Figure C). Fault cores are surrounded by a network of moderate to high angle joint networks which likely grade into the regional joints within the host rock (Figures $\mathrm{C}$ and D). In total, these fault-related structural elements combine to form a zone of locally elevated but heterogeneous permeability within the relatively low permeability bedrock. Extreme permeability heterogeneity, particularly if there are structures that can act as conduits, therefore defines the local hydrogeologic regime that controls groundwater flow from the mine workings to Ralston Creek (for example, Caine and others, 1996).

Figure D4 shows three sets of discrete fault slip surfaces that form a network of likely open structures diffusely oriented with low, moderate, and steep dips with diffuse north-south and northwest-southeast strikes. The north-south normal and left-lateral sets are subparallel to the Illinois fault, the subdrainage containing the Schwartzwalder Mine, and the local hydraulic gradient intersecting Ralston Creek near the mine site. The northwest-southeast reverse set is parallel to the 'Schwartz Trend' subdrainage and the local hydraulic gradient that intersects Ralston Creek after its bend from southeast to southwest (Figures A and B). Although many of the observed slip surfaces have trace lengths on the order of several feet, they are representative of the pervasive brittle deformation observed throughout the Front Range (for example, Caine and others, 2010) and at depth in the mine workings (Wallace and Karlson, 1985). These slip surfaces cut most other structures and are rough walled cracks with mismatched bounding surfaces of likely small aperture and show iron oxide staining indicative of relatively recent, near surface groundwater flow (Figure C).

Figures D1 and D2 show a network of open joint sets of moderate to high intensity measured in surface outcrops near the mine and away from the mine. These measurements are consistent in orientation with those measured in the lower levels of the mine. There are three diffuse sets; one set subparallel to compositional layering, a second set that is steep and subparallel to the Illinois fault zone, and a third set that cuts most of all other structures and that dips at moderate to shallow angles. Each set is subparallel to one of the sets of slip surface and drainages noted above. The east-southeastwest-northwest joint set is also parallel to diffusely subparallel pegmatite dikes. The joint intensity within these dikes is much higher than the host rock into which they intruded (Figure C). The pegmatite dikes are similar to those observed in the Turkey Creek watershed by Caine and Tomusiak (2003) and were thought to be relatively high permeability features. The dikes were reported to have produced large amounts of mine inflow at Schwartzwalder (Wyman and Effner, 2007).

After the Laramide orogeny, which formed many of the brittle structures discussed above, the study area was subject to geomorphological and climatic processes that formed the present landscape. As the Schwartzwalder deposit that formed at depth was stripped of overlying rock by erosion the ancestral Ralston Creek incised its channel into and through the Illinois fault zone. An unknown amount of mineralized rock was lost to erosion as the ancient stream cut its way to its present elevation. Further details of the geology, mineralogy, structure, and geomorphology of the Schwartzwalder deposit and surroundings are beyond the scope of this report and are described elsewhere (for example, Sheridan and others, 1967; Wallace and Karlson, 1985; Anderson and others, 2006).

\section{Mine History and the Mine Site}

The Schwartzwalder deposit was discovered in 1949 and intermittently mined from 1953 to 2000 using a variety of hard rock mining techniques (Figure E; Soule, 1960; Zielinski and 

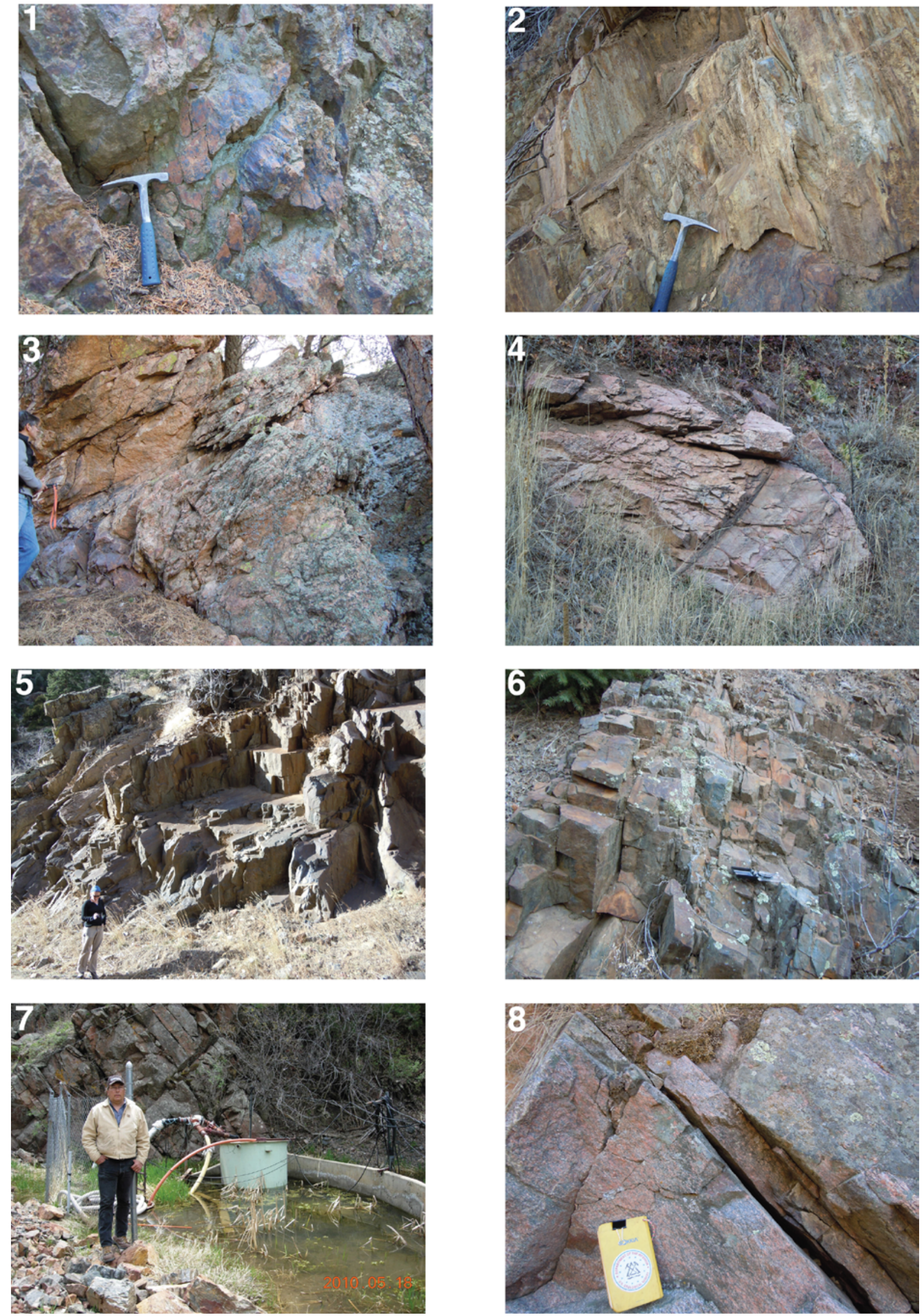
others, 2008). Approximately $17,000,000$ pounds of $\mathrm{U}_{3} \mathrm{O}_{8}$, primarily from pitchblende (amorphous or microcrystalline $\mathrm{UO}_{2}$ ), were produced from the Schwartzwalder Mine (Wallace and Karlson, 1985; Zielinski and others, 2008). Fred Schwartzwalder operated the mine from 1953 until 1956 when he sold his claim and rights to the Denver-Golden Oil and Uranium Company (Downs and Bird, 1965; Soule, 1960). Several private companies as well as the U.S. Atomic Energy Commission completed various mineral exploration activities at the site. In 1965 the Cotter Corporation purchased the mine and has been the operator since then.

The Schwartzwalder Mine comprises a number of adits connecting an underground network of drifts, shafts, winzes, and raises collectively referred to as mine workings. The mine workings extend to a depth of approximately 2,200 ft below the elevation of the adjacent Ralston Creek, which is within $330 \mathrm{ft}$ of the primary adits to the mine (Figure F). The total volume of void space created by the mine workings is estimated to be on the order of 789,000 $\mathrm{yd}^{3}$ (Wyman and Effner, 2007). In addition to the mine workings in the bedrock aquifer, the mine site also comprises alluvial and colluvial sediments, uraniferous mine waste rock, artificial fill, and a variety of industrial facilities and byproducts associated with the mining operations. As Ralston Creek flows by the mine site it interacts with shallow alluvial groundwater and perhaps deeper bedrock groundwater on its way to Ralston Reservoir (Figure A).

Dewatering of the Schwartzwalder Mine workings started sometime before 1960 and continued until May 2000. Before 1960, it is unclear if there was any treatment of the effluent water removed from the workings and it may have been discharged directly to the stream (Soule, 1960). Between 1972 and 1983, water from the workings were treated with

(left facing) Figure C. Outcrop photos from the Schwartzwalder Mine site. (1) Small fault slip surfaces near the Upper Adit. Note the subhorizontal slickenlines in the center of the photo and pervasive iron oxide staining, view approximately south. (2) Foliation in hydrothermally altered muscovite schist cut by low angle joints with extensive iron oxide staining. View is approximately southeast near Minnesota Adit. (3) Extensive faulting and fault-related jointing in a pegmatite dike above the mine, view approximately south. (4) Contrast in joint intensity in a pegmatite dike (upper left) compared to granitic gneiss (lower right), view approximately south. (5) Long trace length, pervasive low angle joints that cut the subvertical foliation that also has subparallel joints cutting it. The host rock is hornblende gneiss adjacent to the stream sample site "Stream Below (1119106)", view approximately southwest. (6) Low angle joint in hornblende gneiss just west of the upper level adit, view approximately southwest. (7) Open joints in granitic gneiss at Sump 1, view approximately south. Photo courtesy T. Waldron, CDRMS. (8) Detail from 7 showing iron oxide staining in subvertical joints that cut foliation.
$\mathrm{BaCl}_{2}$ and settling methods in open-air ponds adjacent to the mine and Ralston Creek (Lammering, 1973; Yang and Edwards, 1984; Wyman and Effner, 2007). In 1983 an indoor mine water treatment plant was constructed at the mine site in order to remove suspended and dissolved constituents from the mine effluent (Zielinski and others, 2008). Between 1990 and 1992, four in-ground sumps with pumps were installed in the alluvial sediments adjacent to Ralston Creek (Wyman and Effner, 2007). Groundwater from the sumps was pumped to the treatment plant, treated, and discharged to Ralston Creek. All but one of the sumps was shut down in June 2002. The final sump, Sump 1, which was the farthest downstream at the mine site, recirculated water from 2002 and was shut down in April 2008. In early July and mid-August 2010 Sumps 1 and 4 respectively were reconditioned and brought online to again provide alluvial water to an updated water treatment plant employing ion exchange columns for the removal of uranium. Monitoring Well 9 was also used for pump and treat operations starting in mid-August 2010. Three new sumps, 5, 8, and 9 , were constructed in the late fall and have been operational to varying degrees and to stay within treatment capacity of 200 gallons per minute since November 2010 (Cotter Corporation, written commun., 2011).

The Cotter Corporation has conducted mining and water treatment under a variety of permits issued by the State of Colorado, one of which allows for discharge of treated mine effluent to Ralston Creek (Colorado Division of Public Health and the Environment Discharge Permit number CO-0001 244). Water quality in Ralston Creek and discharged mine water effluent have been monitored by different government and private entities, at varying times for varying durations (for example, Lammering, 1973; Yang and Edwards, 1984; Wyman and Effner, 2007; Zielinski and others, 2008). The latest water quality monitoring included direct sampling of Ralston Creek, the sumps, and a number of monitoring wells completed in the surficial sediments at the mine site and in bedrock away from the mine site. The most complete sampling record and data are currently (2010) found in the Environmental Protection Plan submitted to the Cotter Corporation and DRMS by Whetstone Associates, Inc. (2010).

Dissolved U, Ra, Th, Mo, Fe, $\mathrm{Cu}, \mathrm{As}$, and $\mathrm{SO}_{4}$ in particular measured in Ralston Creek downstream from the mine site show anomalously high concentrations compared to concentrations measured in surface water of the eastern central Front Range of Colorado (Zielinski and others, 2008). These elements are of interest because they may be indicative of a mine-related source, have potential toxicity, and are mobile in oxygenated near-neutral $\mathrm{pH}$ surface water. Water quality measurements made by the U.S. Geological Survey in November, 2010 show high $\mathrm{U}$ concentrations consistent with values determined by DRMS, the Cotter Corporation, and Whetstone Associates.

In addition to shallow groundwater in the alluvium, the degree to which deeper groundwater in the Proterozoic bedrock is a source of contamination to Ralston Creek is unclear. In May 2000, the dewatering pumps near the base of 


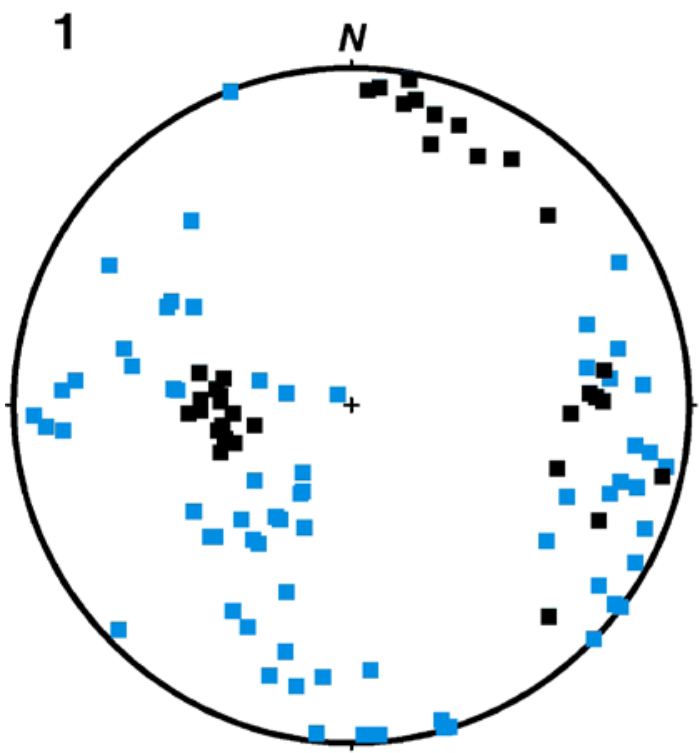

3
Open Joints

Poles all joints at surface $(n=102)$

Poles to joints at Stream Below site $(n=35)$

Contour interval $=$ 2 sigma

Great circles and

mean vectors to

joint sets

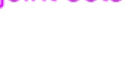

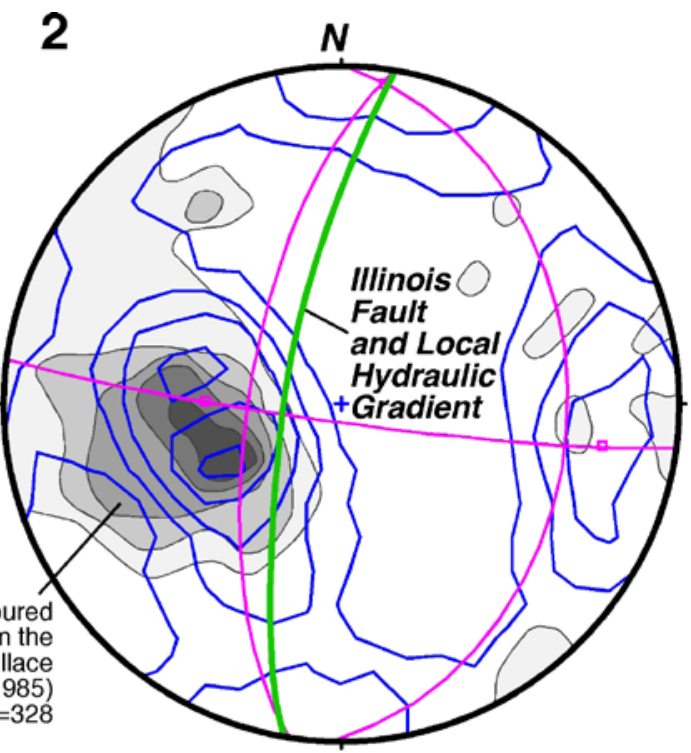

Compositional
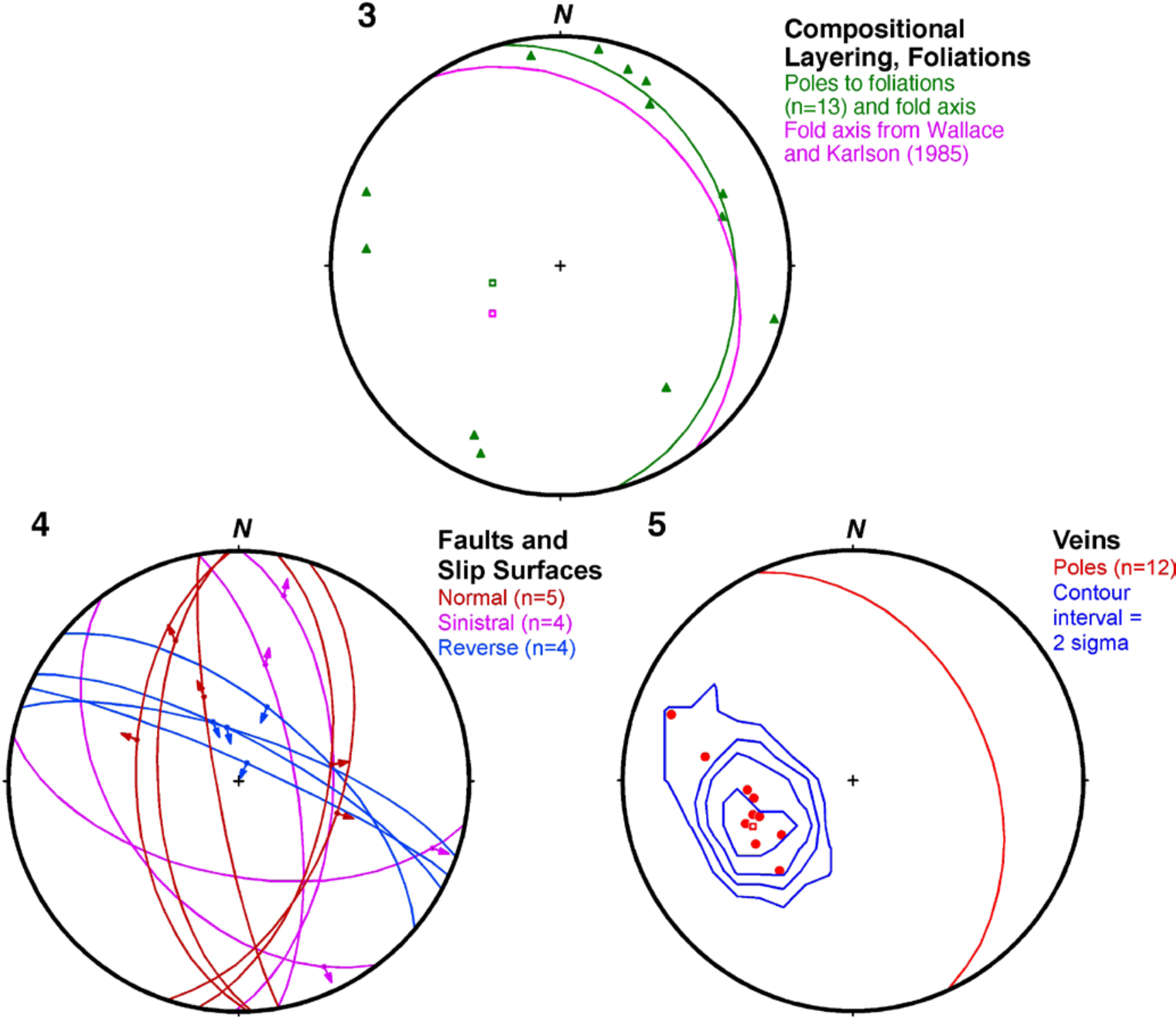
(left facing) Figure D. Lower hemisphere, equal area projections (Allmendinger, 2004) showing: (1) poles to open joints collected at the surface in each of the major rock types. Blue poles are all of the data and black poles are from outcrops at the water-sampling site "Stream Below Mine" where the quartzite and garnet-biotite-gneiss transition zone rocks intersect Ralston Creek. (2) Kamb (1959) contoured poles to joints from 1 (blue unshaded contours) superimposed on contoured open joint data (gray shaded contours) collected by Wallace and Karlson (1985) in the lower levels of the Schwartzwalder Mine. An average orientation of the Illinois fault zone in the mine is shown as a light green great circle that is subparallel to the local hydraulic gradient. Mean great circles and vectors for each of the three major open joint sets are shown in pink. (3) Poles to compositional layering and foliations from the primary rock types. The green great circle and associated pole result in a pi axis for the major fold hinge coincident with that determined by Wallace and Karlson (1985) shown in pink. (4) Great circles of fault slip surfaces measured in the vicinity of the mine site show slip linears with the arrows pointing in the direction of hanging wall motion. Faults with normal and right lateral (red), left lateral (pink), and reverse (blue) kinematic indicators were observed. (5) Poles (red) and Kamb contours (blue) to carbonate and other fault veins observed primarily along the track of adit portals at the mine site. The pink pole and great circle show the mean orientation of these structures.

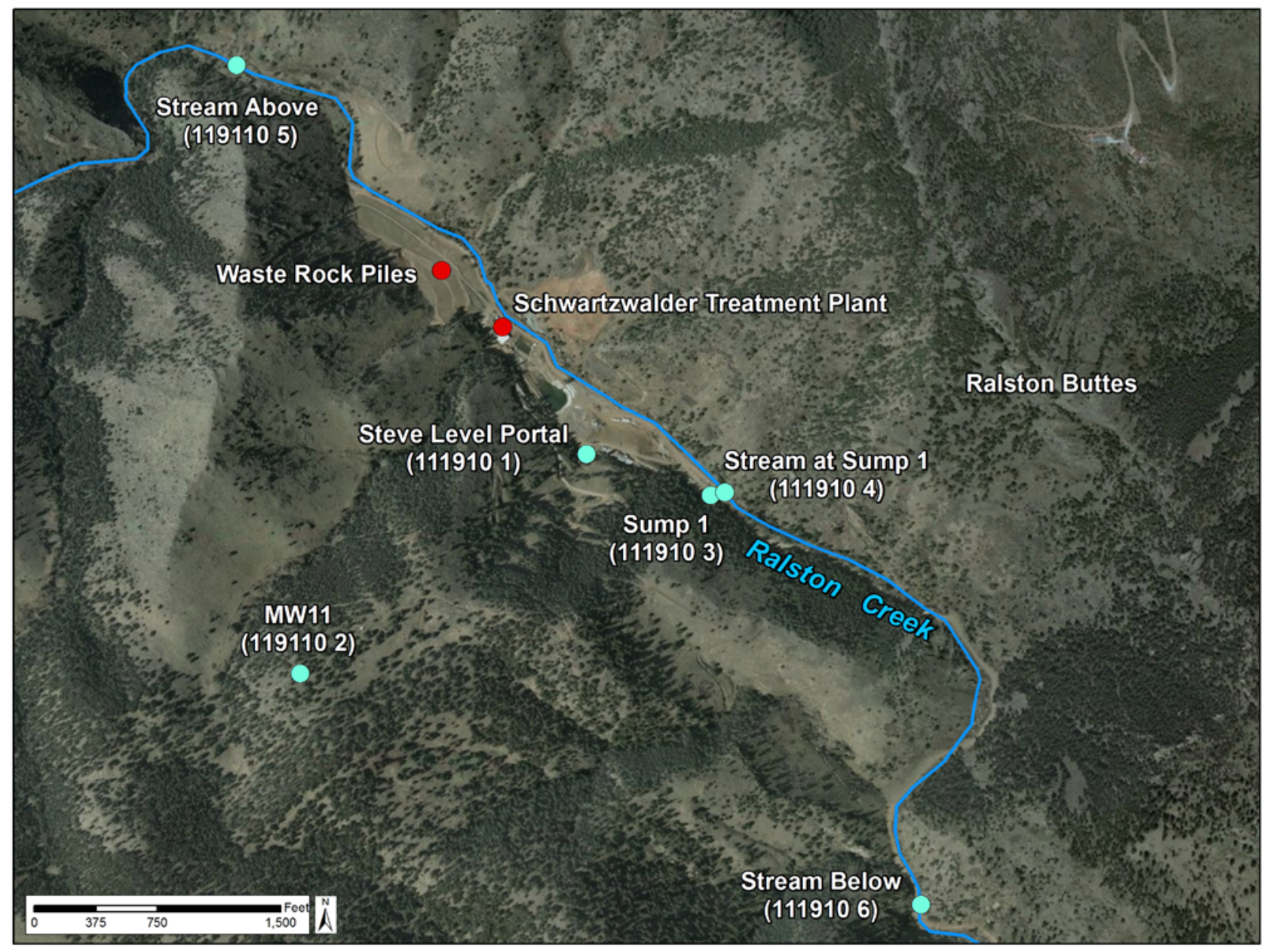

Figure E. Aerial photograph showing the Schwartzwalder Mine site, U.S. Geological Survey water sampling sites and sample numbers from November 19, 2010. 


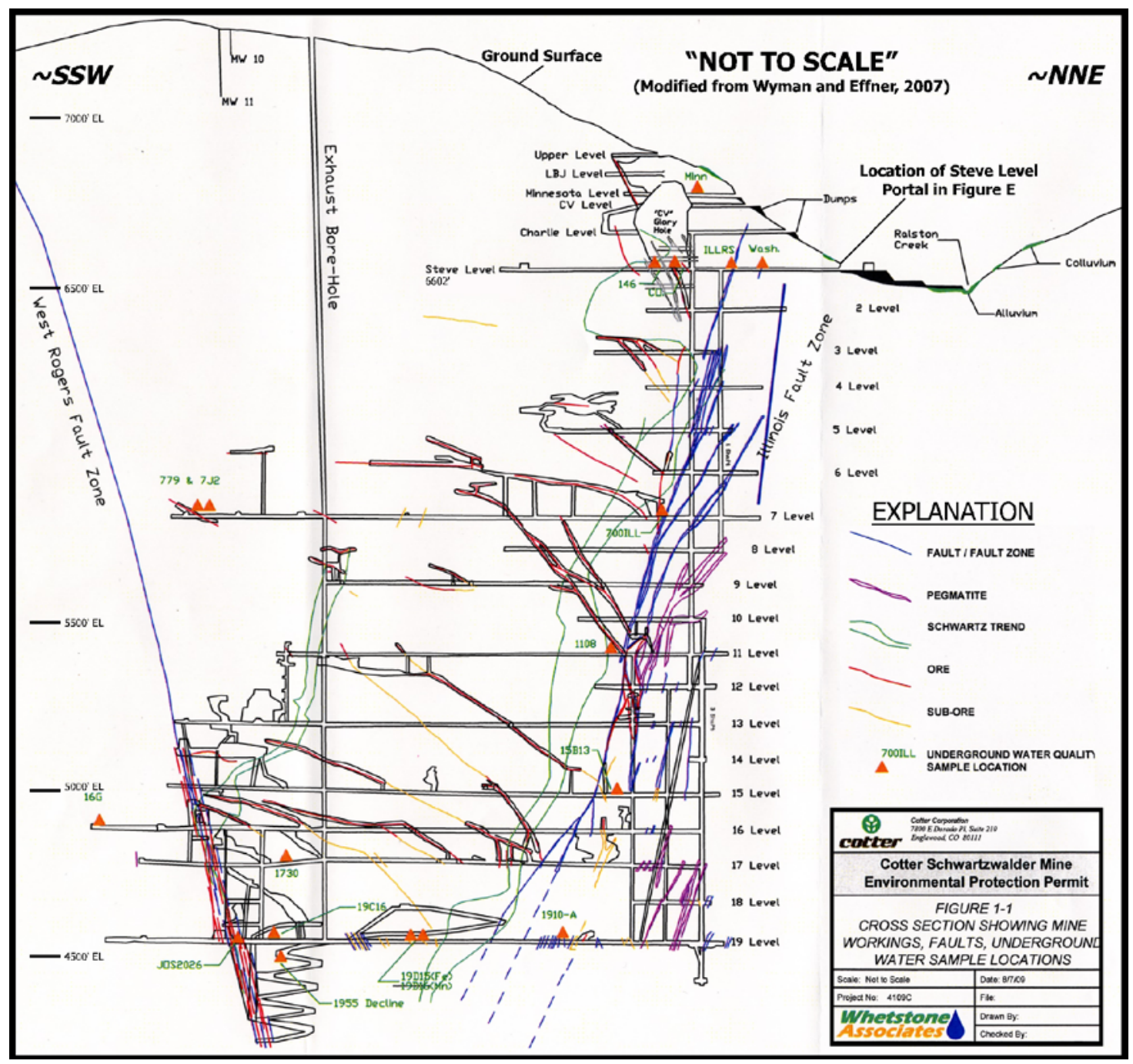

Figure F. Schwartzwalder Mine workings and geologic cross section from Cotter Corporation (modified from Wyman and Effner, 2007).

the underground mine workings were turned off and natural groundwater was allowed to flood the workings. Currently (2010) there are approximately 140,000,000 gallons of uranium and other heavy metal bearing water that sit in the mine workings (Wyman and Effner, 2007). Collectively this water is referred to as the "mine pool" and its upper surface was at an elevation approximately $15 \mathrm{ft}$ below the floor of the primary adit to the mine on July 27, 2010 and approximately $32 \mathrm{ft}$ above Ralston Creek adjacent to the adits.

\section{General Comments on Wyman and Effner, 2007}

The data compiled and reported in Wyman and Effner (2007) are extensive. The broad range of reported hydrologic and geochemical data through time are particularly useful and unique. However, data interpretation could be improved. Method descriptions are somewhat scattered and in some 
cases missing, along with inconsistent concentration units, making it occasionally difficult to determine the basis for statements made and quantitative results presented. Citation of relevant references and existing knowledge is incomplete. This weakens arguments in support of various conclusions. Finally, there are a number of errors in conceptual understanding, inappropriate use of these concepts in discussions, some errors in calculations, and errors in reporting the results of some calculations. The following specific comments are meant to be a constructive critique on the Wyman and Effner (2007) report with a focus on identifying gaps in the information, to help bolster the interpretations, and identify future research needs at the Schwartzwalder Mine site.

\section{Specific, Section by Section Comments on Wyman and Effner, 2007}

\section{Section 2.4, Economic Geology, Page 5}

1. This section starts with a brief description of the "Schwartz Trend" that should be attributed to the originators of this term. The Schwartz Trend is what Wallace and Karlson (1985) refer to as a "transition zone" of relatively more brittle garnet-biotite gneiss and quartzite units found between relatively less brittle hornblende gneiss and muscovite schist units in the metasedimentary sequence. Wyman and Effner (2007) state that this transition zone is "brittle" and that the ore body is hosted in this zone. However, the ore minerals are primarily localized in fault veins that formed in this transition zone. The key hypothesis of Wallace and Karlson (1985) was that the garnet biotite gneiss and quartzite units were preferential sites for brittle deformation during shallow Laramide faulting and thus fluid flow. This fluid flow localized the deposition of the carbonate hosted pitchblende deposits in and near these structures; the entire transition zone itself is not a host of significant mineralization.

2. Coffinite is noted as a "dominant ore mineral" and it is referred as a "uranium sulfate." This is incorrect. Coffinite is a uranium-bearing silicate $\mathrm{U} 4+[(\mathrm{SiO} 4),(\mathrm{OH}) 4]$ (Strunz and Nickel, 2001) and is of secondary importance compared to pitchblende.

3. Figure 1-1 (Figures $\mathrm{F}$ and $\mathrm{G}$ in this report), Mine Cross Section. This figure is important for understanding geometric aspects of the mine workings with respect to the water table or potentiometric surface, hydraulic gradients, and the ultimate "static" water level of the mine pool. Yet the figure is marked as being "Not to Scale," there is no section line location, and there are no supporting notes of explanation in the figure. It would be helpful to have assurance of the proper scale as well as the relation of this figure to the topography and locations of monitoring wells 11 and 10.

\section{Section 2.6, Mine Layout, Page 8}

1. There is a discussion and presentation in Table 3 of mine coordinates and elevations where two datums are referenced. It is unclear why two datums are reported and the datum ultimately used in the discussion is not explicitly stated. There also are inconsistencies in what is reported as the total mine depth throughout the report and in various calculations. Calculation of the reported mine depth of " 2,222 feet from the Steve Level portal to the bottom of the spiral decline" cannot be repeated using the information given. A value of 2,200 feet is later used for the total mine depth to predict the "static level" of the mine pool, yet no justification is provided for use of 2,200 feet compared to 2,222 feet.

\section{Section 3.2, Flow in Ralston Creek at the Schwartzwalder Mine, Pages 12-16}

1. Streamflow measurement data are presented for Ralston Creek in this section and statements are made regarding gaining compared to losing reaches of the stream. Unfortunately, no information is presented on the accuracy or precision of the measurements in the body of the report. This is particularly critical since flow metering by the reported method can have errors as large as \pm 20 percent, particularly in mountain streams (for example, Rantz, 1978; Sauer and Meyer, 1992). When measurement errors of this magnitude are considered, conclusions regarding specific locations and importance of gaining or losing reaches in a stream may be suspect. Highly precise and accurate measurements of streamflow are critical for determining the location(s) and amount(s) of flow contributed by bedrock, faults, and the mine pool via the alluvial aquifer to the stream channel.

2. Some information and analysis is presented on flooding hazards and these analyses are focused on the mine waste rock pile. Flow magnitude estimates are provided for 50and 100-year floods at the mine site and are on the order of 4,900 to 5,700 cubic feet per second $\left(\mathrm{ft}^{3} / \mathrm{s}\right)$. A 100-year peak flow of $119 \mathrm{ft}^{3} / \mathrm{s}$ was used for the waste rock stability analysis, which appears inconsistent with other estimates of flow for a 100 -year flood. No analysis is provided for what a 100-year flood with peak flows on the order of thousands of cubic feet per second might do to surface installations, waste rock piles, contaminated alluvium, mine adits and bulkheads.

Sampling in Ralston Creek above and below the waste rock piles has not shown recent contamination. A cap rock cover composed of 3 feet of rock and 1 foot of soil 


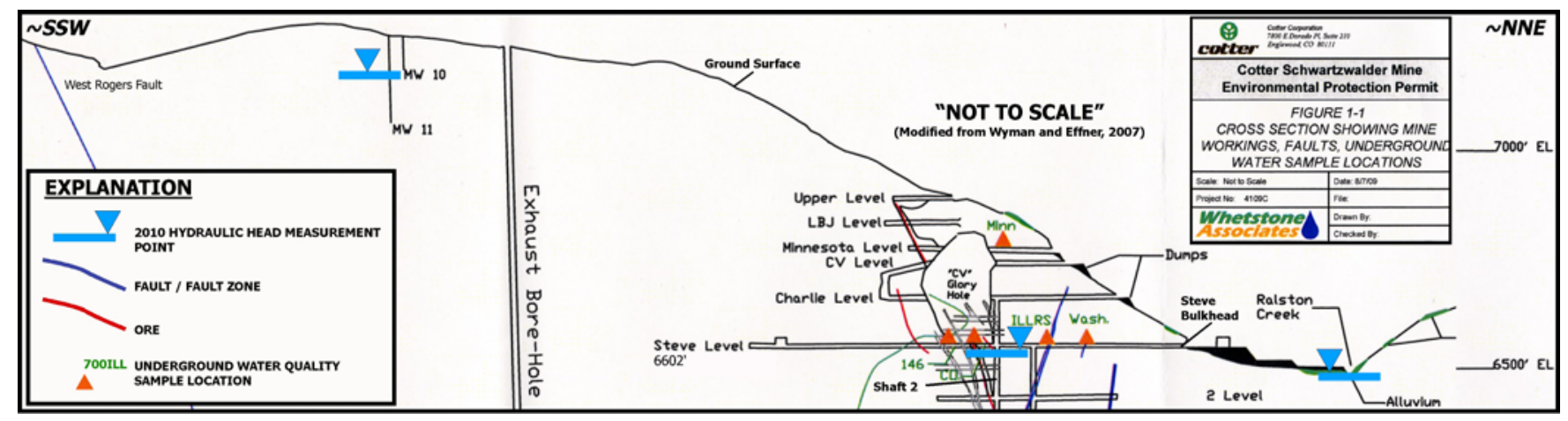

Figure G. Schematic cross section of the Schwartzwalder Mine workings showing elevations of hydraulic head in 2010 above the mine, in the mine, and at Ralston Creek (Modified from Wyman and Effner, 2007).

was installed on the waste rock piles in 2003, however, potential for the cover to fail over time thus allowing precipitation to infiltrate and leach the piles has not been addressed. In addition, shallow groundwater flow from the hill slope above and southwest of the waste rock piles could also leach contaminants from the unsaturated zone down to the saturated zone if the water table rose, and potentially enter the shallow aquifer, depending on the depth of any capillary fringe and the redox conditions. It is noted in Wyman and Effner (2007) that Ralston Creek adjacent to the waste rock piles is a losing reach. If this is true, leaching of dissolved uranium and other contaminants from the waste rock piles might not be detected because of the loss. Furthermore, if contaminants are being leached at the waste rock piles, they may be transported in the shallow alluvial aquifer to reemerge at downstream gaining reaches where groundwater is discharged.

\section{Section 4.1.1, Depth to Water and Groundwater Flow, Pages 17-19}

1. A minor correction to the report is that the road to MW11 from the mine site is not reclaimed and is accessible with four-wheel drive or by foot.

2. The hydraulic gradient at the MW10 and MW11 well pair have a vertical component, but it is not appropriate to assign a vertical gradient to the entire mine site based on the well pair. When wells are drilled in fractured rock, new connections within the wells and between wells are made that did not exist before (for example, Shapiro and others, 1991). Conditions in such wells may not accurately represent the local-scale hydraulic gradients and provide little information regarding the larger-scale or gradient conditions as a function of depth. It is clear from data provided in the report that nonvertical components of flow occur in the vicinity of the mine (for example, based on excavation, drill, and pumping data in pegmatite bodies that were encountered during mine construction and dewatering). It is also likely that lateral flow is a component of the flow system at depths below the Steve Level.

3. Page 18 , conclusion number 4; indicating horizontal compared to vertical hydraulic conductivity is problematic. Although vertical flow in discrete features such as the Illinois fault may be locally dominant, such structures may also guide flow horizontally. Flow magnitude and direction depends on the internal structure of the fault zone and the hydraulic gradient driving the flow. Additionally, there are pervasive, moderate to low angle joint sets that cut subvertical features such as foliations and these subhorizontal features are more likely to affect flow than less permeable foliations (Figures $\mathrm{C}$ and D; for example, Wallace and Karlson, 1985; Hsieh and others, 1999). There are not enough hydraulic data at appropriate scales to make informed determinations of hydraulic anisotropy in the bedrock aquifer.

4. Page 18, conclusion number 5; a statement such as 'Assuming the bedrock aquifer is unconfined...' would be appropriate when referring to "specific yield."

5. Page 18, conclusion number 5; the statement that infiltration is "about 3 inches per year" is not supported from previous work or otherwise supported by data. In Bossong and others (2003) a series of direct and indirect measurements of evapotranspiration and calculation of "infiltration" as a proxy for "groundwater recharge" were made in the Turkey Creek watershed of Jefferson County, Colorado. The Turkey Creek watershed is similar in geology, topography, elevation, climate, vegetation, and other watershed parameters to the Schwartzwalder Mine site and surrounding area. Bossong and others (2003) note that "infiltration" is highly episodic and variable and is 
strongly controlled by vegetation and other parameters; average annual infiltration of 3.9 inches, varying from 0 inches to 7.15 inches (Bossong et al., 2003, Table 11; Figure 17; near zero infiltration was not measured but based on linear interpolation.). The value used by Wyman and Effner (2007) may be a reasonable value for infiltration to start with. However, given the year-to-year variations reported in Bossong and others (2003) it is not appropriate to use a single value, particularly one that may not be representative.

6. The estimate of infiltration is used to further estimate "drainable porosity" of the bedrock. If the range of values of infiltration from Bossong and others (2003) are used, porosity estimates using the approach of Wyman and Effner (2007); "infiltration $\div$ increase in water level" could range from 0.2 to 1.2 percent.

\section{Section 4.2, Groundwater in Alluvium, Pages 20-21}

Most of the wells drilled into the alluvium penetrate into the bedrock providing critical information on the depth to bedrock (Table 11 in Wyman and Effner, 2007). Of the 10 wells drilled into alluvium 5 of them are screened only in the alluvium (MW00 - MW4) while the other 5 are partially screened in alluvium and in bedrock (MW5R - MW9). Without nested wells - ideally one screened in alluvium only and one screened in bedrock only, both within the same nest - it is impossible to make robust determinations regarding hydraulic head differences between these two primary aquifers or chemical differences among different water.

\section{Section 4.2.2, Alluvial Permeability Tests, Page 23, Bullet Number 4}

The comment "The test did not appear to influence the chemistry of Ralston Creek or any of the wells or sumps adjacent to the stream." is relevant and worthy of discussion. Pumped water in the alluvium is expected to flow towards the well and would not be expected to have a major effect on the in-stream chemistry. Stream water recharge to the alluvial aquifer in losing reaches of the stream is a pathway for contaminant dissolution. Stream water that flows through the contaminated alluvium and artificial fill materials may pick up solutes and reenter the stream where the alluvial deposit pinches out (Figure B). The hydraulic conductivity of the alluvium is reported to be up to four orders of magnitude greater than the bedrock. High flow rates from the sumps are consistent with high hydraulic conductivity in the alluvium. Such high conductivities would not impede any hydraulic connection to Ralston Creek, however quantitative separation of different flow components between the bedrock, alluvium, and stream have not been demonstrated in Wyman and Effner (2007).

\section{Section 4.3, Seeps, Page 27}

Stated here and elsewhere in the document, hornblende gneiss unit is "relatively impermeable." Wyman and Effner (2007) report measured values of hydraulic conductivity $(K)$ of the fractured bedrock that ranges between approximately $10^{-5}$ and $10^{-9} \mathrm{~cm} / \mathrm{s}$. For comparison, literature data indicate that sandstone $K$ s range from approximately from $10^{-4}$ to $10^{-8} \mathrm{~cm} / \mathrm{s}$ (Freeze and Cherry, 1979). Sandstones commonly form aquifers and the reported $K$ s for the bedrock at the Schwartzwalder Mine are well within this range. Most of the population of the western mountain suburban areas of Denver rely on individual water wells drilled in essentially the same rocks as those found at Schwartzwalder (Snow, 1972). Although the effective porosity and bulk permeability may be low, the rock units at the Schwartzwalder Mine site do qualify as an aquifer.

Seeps or springs are sites of groundwater discharge. Seeps commonly emerge near breaks in slope along the incised margins of stream channels. Seeps and springs also commonly occur at contacts between lithologic units of contrasting hydraulic conductivity such as bedrock/alluvium contacts or where there are contrasts in fracture intensity, alteration, and(or) weathering. The location of Sump 1 is where the alluvial aquifer and valley are narrowest at the mine site. Just behind sump 1 the bedrock outcrops and forms the contact with the alluvial aquifer as well as a major brake in slope. Figure $\mathrm{C}$ shows the outcrop and large aperture joints, likely enhanced by mechanical weathering, in feldspar-rich granitic gneiss. The area around Sump 1 presents a potential permeability pathway connecting bedrock, alluvium, and the shallow subsurface below the alluvium. This is an important area where monitoring for the transport of mine pool water towards the creek water should be continued.

\section{Section 5.1, Conceptual Hydrologic Model, Pages 27-29}

Many elements of the "Pre-Mining," "During Mining," and "Post-Mining" conceptual hydrogeologic models are plausible, but there are also several misconceptions and a lack of data to support a number of the statements made. The depth of weathered bedrock and its permeability heterogeneity are largely unknown; bedrock is relatively unweathered in the near surface in numerous areas. Although relatively unweathered, this does not mean joints are absent. There is notable evidence for distinct, open joint sets of moderate intensity, and near surface orientations that match those observed deep within the mine (Figures C and D, Wallace and Kalson, 1985).

The statement that "at depth, the hydraulic gradients in bedrock were not... influenced by Ralston Creek..." is not supported by data. The depth of "active circulation" of groundwater (for example, Robinson, 1978; Manning and Caine, 2007) is rarely constrained and could include depths approaching the total depth of the mine. The potential role of various fully penetrating discrete structures such as the Illinois 
fault zone or other major faults in the watershed should be considered. The permeability structure and geometry of the Illinois fault zone, if and where it may cross Ralston Creek, and its potential to be a conduit for groundwater flow is not adequately addressed.

The hydraulic condition found in the bedrock aquifer within the mine and vicinity is not well characterized in Wyman and Effner (2007). Given the high degree of correlation among (1) average annual precipitation and apparent infiltration responses in mine inflows, (2) water level fluctuations in the bedrock groundwater monitoring well MW11, (3) unimpeded connection between the unflooded mine workings and atmosphere, and (4) mine pool rebound or the return of the water level to its pre-mining equilibrium level (Wyman and Effner, 2007), the bedrock aquifer is best characterized as unconfined.

Finally, the statement that the "capture zone" is limited by topography is an oversimplification because of the additional influence of discrete features such as the fault zones. The concept of a "capture" area that readily allows infiltration of precipitation to the groundwater flow system also implies that the aquifer is unconfined.

\section{Section 5.2, Mine Inflow, Pages 29-40}

\section{Subsection 5.2.1, Pumping Records, Pages 29-32}

1. Towards the end of page 30 it is noted that the mine workings extend more than 2,000 feet "below the premining potentiometric surface...". However, no data are presented that establish the elevation or geometry of the pre-mining potentiometric surface. The statement contradicts another statement on page 39 where it is noted that the "pre-mining static water levels were not measured prior to development of the Schwartzwalder deposit in the 1950s...".

2. Figure 19. It is not clearly discernable what is plotted in this figure, as it is not adequately described anywhere in the text or caption. The vertical blue lines appear to show the extremes of groundwater inflow into the mine for each month from 1995 through 1999. The red squares appear to be the average monthly inflows for the same time period. This figure is used for estimating several parameters in the report but in particular it is used to evaluate infiltration of precipitation in the vicinity of the mine. A comparison is made between rates of mine inflow and precipitation, but a plot of both data sets is not shown, thus requiring the reader to assume validity of the statements. The precipitation record in Figure 6 is from May 1978 through July 2007 at Ralston Reservoir and the mine inflow record is from 1995 through 1999. A more meaningful analysis suggested here is to cull the precipitation data and explore it over the same time period as the mine inflow data.
3. There may be significant differences between the precipitation, temperature, and the north facing vegetation regime along the upper reaches of the mine site in the foothills (about 7,050 ft) compared with the location of Ralston Reservoir nearly 1,000 ft lower on the High Plains grassland (Figure A). These environmental differences may have a large effect on water availability for groundwater infiltration and should be accounted for in any future studies of the mine site water budget.

4. A lag time for precipitation to infiltrate into the mine is suggested; however, this average lag time is not constant throughout the year. For example, increasing average precipitation from February through May positively correlates with increasing mine inflow from April through May; between May and June the mine inflow was still increasing yet precipitation was decreasing. From June through December mine inflow and precipitation on average appears to return to a positive correlation. These relations may have more to do with increased precipitation in late spring-early summer and the buildup of head sufficient to drive flow rather than a constant lag as suggested by Wyman and Effner (2007). The role of evapotranspiration (ET) may also be more important than frozen ground and ET is not well constrained in this report. Determination of groundwater recharge is challenging and should include a full accounting of all parameters such as ET to develop realistic estimates and minimize uncertainty.

5. The final problem in this subsection is the lack of detail provided in the derivation of average monthly mine inflows from infiltration of precipitation. Figure 19 indicates that the lowest average mine inflow occurs in February and March and this value is about $180 \mathrm{gpm}$ (gallons per minute). This may be a 'base level' amount of inflow into the mine. If this assumption is correct, average inflows greater than $180 \mathrm{gpm}$ may be augmented by local infiltration because of precipitation minus ET.

\section{Subsection 5.2.2, Sources of Inflow, Pages 32-34 and Part of Subsection 5.2.4, Projected Final Water Level, Pages 39-40}

1. The statement "slow infiltration of groundwater through unfractured bedrock" is potentially misleading. All of the bedrock at the Schwartzwalder Mine and vicinity is fractured and locally faulted at varying intensities. Field observations at the mine site and from other areas in the eastern central Front Range indicate that the Proterozoic bedrock is pervasively jointed at the surface and at depth (Snow, 1968; Robinson, 1978; Caine and Tomusiak, 2003; Caine and others, 2008; Figure D). Numerous measurements of open joints within the Schwartzwalder Mine, at depth, are provided in Wallace and Karlson (1985; Figure D). 
2. Use of the Thiem equation is presented in order to estimate the "steady state inflow" into the mine at "its maximum extent." The Thiem equation is traditionally used to estimate well discharge after drawdown has reached steady state (Driscoll, 1986). In addition, the approach is not clearly described, key assumptions are not stated, and thus the results are not repeatable. The equation used is taken from Singh and Atkins (1984):

$$
Q=\frac{2 \pi L K H}{1 n\left(R / r_{h}\right)}
$$

where $Q=$ volumetric inflow to the mine $\left[\mathrm{L}^{3} / \mathrm{T}\right], L=$ length of the well screen [L], $K=$ hydraulic conductiity [L/T], $H=$ drawdown [L], $R=$ radius of influence [L], and $r_{h}=$ radius of the well bore or mine workings $[\mathrm{L}](\mathrm{L}=$ length and $\mathrm{T}=$ time; modified from Wyman and Effner, 2007). The unstated assumptions include: (1)Darcy's law is not violated, (2) the well fully penetrates the saturated aquifer being tested, (3) there are no head losses during pumping, (4) radial flow that has reached steady state, (5) a horizontal water table or potentiometric surface, and (6) an aquifer with isotropic and homogeneous hydraulic conductivity that behaves as a continuous medium (for example, Driscoll, 1986; Kruseman and de Ridder, 1990).

Although many of the assumptions behind use of Equation 1 are not adhered to, in practice, the use of this equation can result in valid estimations if its use is properly formulated and qualified. However, in the case of the Schwartzwalder Mine, several factors make the use of Equation 1 problematic. (A) The water table or potentiometric surface is not flat; based on the topography, the pre-mining surface must have had a significant slope. (B) Equation 1 is specifically for a confined aquifer (Singh and Atkins, 1984; Driscoll, 1986). Wyman and Effner (2007) do not establish whether the aquifer is confined or unconfined, but their data are most consistent with an unconfined condition. (C) Because of the topography and the high ratio of length to width (aspect ratio) of the mine workings, it is highly unlikely that inflow to the mine was radial during drawdown. (D) The aquifer is probably heterogeneous and locally anisotropic with many discrete features; it is not a continuous medium at the scale of the mine working. (E) Use of a wellbore that is 500 feet in diameter representing the mine workings may violate Darcy's law because of partial saturation and the large aspect ratio of the mine workings.

When applying Equation 1 to the Schwartzwalder Mine, the results from Wyman and Effner (2007) cannot be repeated. Table A shows results of spreadsheet calculations of mine inflow using the same approach and input values used by Wyman and Effner (2007) to estimate "inflow to the mine from unfractured bedrock at full depth".

For this calculation, Wyman and Effner (2007) specify all input values except $R$. The calculated value for $Q$ reported in Wyman and Effner (2007) is 64 gpm. From Table A it can be seen that an inflow of about $64 \mathrm{gpm}$ to the mine using the input values provided requires a value of $R$ that equates to a circular radius of influence of about $500 \mathrm{ft}$, enclosing a "capture area" of about 18 acres; a value not reported in Wyman and Effner (2007).

3. In Subsection 5.2.4, Projected Final Water Level, on pages 39-40, Wyman and Effner (2007) use the Thiem equation to predict the final static water level in the Schwartzwalder Mine pool. To predict the static water level, Equation 1 was rearranged to provide two new equations for $\mathrm{K}$ and $\mathrm{H}$ (Wyman and Effner, 2007). The equation for $K$ was iteratively solved to obtain a value of $180.1 \mathrm{gpm}$ average inflow, the value reported when the mine was fully excavated. The equation for $\mathrm{H}$ was solved for a value that would produce a flow of $1.2 \mathrm{gpm}$ observed during the "pilot plant pumping test" conducted during the summer 2007 when groundwater elevation in the mine was close to the Steve Level. Finally, the values of $K$ and $H$ were used in both equations to iteratively solve for a value of $L$, equated to the saturated thickness of the aquifer as a proxy for the final static water level of the mine pool. Using this approach, values of $L$ cannot be lower than the pump or higher than the water level measured at the end of the pilot pumping test.

There are problems with the approach of Wyman and Effner (2007) that make it inappropriate for predicting the final static water level of the mine pool. All of the assumptions noted above for Darcy's Law apply to any use of Equation 1 and most are not adhered to. Values used for $R$ are not explicitly provided or justified. The only data provided are from discharge into the mine, $Q_{1}=180.1 \mathrm{gpm}$ and discharge from the pilot plant pumping test, $Q_{2}=1.2 \mathrm{gpm}$. Assuming that values for $R, r_{\mathrm{h}}, K$, and $L$ are held constant Equation 1 can be expressed as,

$$
Q_{1}=\frac{2 \pi H_{1} L K}{1 n\left(R / r_{h}\right)} \text { and } Q_{2}=\frac{2 \pi H_{2} L K}{1 n\left(R / r_{h}\right)} .
$$

The only variables that can be solved for are $H_{1} / H_{2}=Q_{1} /$ $Q_{2}=150.0$. If either $H_{1}$ or $H_{2}$ were known, the other could be solved for. $H_{2}$ is unknown. $H_{1}$ can be iteratively solved for because $H_{1}$ must approximately equal the depth of the mine minus the original depth to water, but the solution is not viable because the original depth to water is not known. The second problem with using this approach is the assumption that the pumping level for the pilot plant-pumping test $(6,575 \mathrm{ft})$ represents a point $\mathrm{H}_{2} \mathrm{ft}$ below the static water level (SWL). The actual drawdown, which should be about $1.4 \mathrm{ft}$, is superimposed on the unknown mine rebound water level trend, not on the SWL. The mine rebound trend remains unknown after a new pumping interval is started, and no data are created that allows the SWL to be determined.

The physical controls on the groundwater flow system are not accounted for in the Thiem calculations of Wyman and Effner (2007). Ultimately, the final mine pool water elevation will be controlled by the geomorphology, three-dimensional head regime, the bulk hydraulic conductivity of complex bedrock lithologic and structural heterogeneities, the mine workings, and transients imposed on the system by seasonally 
Table A. Expanded estimates of inflow to mine for 2,200 foot, full depth from Wyman and Effner (2007).

[Abbreviations: $\mathrm{ft}$, foot; $\mathrm{cm}$, centimeter; ac, acre; s, second; sqrt, square root; gpm, gallons per minute; $\mathrm{r}$, radius; sqrt (area/ $\pi$ ). SI Conversions: $1 \mathrm{ft}=$ $30.48 \mathrm{~cm} ; 1 \mathrm{ac}=4.05 \times 10^{7} \mathrm{~cm}^{2} ; 1 \mathrm{~cm}^{3} / \mathrm{s}=0.016 \mathrm{gpm}$. Thiem equation (Singh and Atkins, 1984) $\left.\mathrm{Q}=2 \pi \mathrm{L} \mathrm{K} \mathrm{H} / \ln \left(\mathrm{R} / \mathrm{r}_{\mathrm{h}}\right)\right]$

\begin{tabular}{|c|c|c|c|c|c|c|}
\hline & Value & Unit & SI value & Unit & Radius & \\
\hline $\mathrm{L}=$ Length of well screen & 2,200 & $\mathrm{ft}$ & 67,056 & $\mathrm{~cm}$ & & \\
\hline $\mathrm{K}=$ Hydraulic conductivity & $1 \mathrm{E}-07$ & $\mathrm{~cm} / \mathrm{s}$ & $1 \mathrm{E}-07$ & $\mathrm{~cm} / \mathrm{s}$ & & \\
\hline $\mathrm{H}=$ Drawdown & 2,200 & $\mathrm{ft}$ & 67,056 & $\mathrm{~cm}$ & & \\
\hline $\mathrm{R}=$ Radius of influence (9 acre area) & 9 & ac & $3.64 \mathrm{E}+08$ & $\mathrm{~cm}^{2}$ & 10,767 & $\mathrm{~cm}$ \\
\hline $\mathrm{R}=$ Radius of influence (18 acre area) & 18 & ac & $7.28 \mathrm{E}+08$ & $\mathrm{~cm}^{2}$ & 15,227 & $\mathrm{~cm}$ \\
\hline $\mathrm{R}=$ Radius of influence $(56.8$ acre area $)$ & 56.8 & ac & $2.30 \mathrm{E}+09$ & $\mathrm{~cm}^{2}$ & 27,056 & $\mathrm{~cm}$ \\
\hline$r_{h}=$ Radius of well bore $(500 \mathrm{ft}$ diameter, $r=250 \mathrm{ft})$ & 250 & $\mathrm{ft}$ & 7,620 & $\mathrm{~cm}$ & & \\
\hline$Q(9$ ac $)=$ & 8,172 & $\mathrm{~cm}^{3} / \mathrm{s}$ & 129.5 & gpm & & \\
\hline$Q(18$ ac $)=$ & 4,081 & $\mathrm{~cm}^{3} / \mathrm{s}$ & 64.7 & gpm & & \\
\hline$Q(56.8 \mathrm{ac})=$ & 2,230 & $\mathrm{~cm}^{3} / \mathrm{s}$ & 35.3 & gpm & & \\
\hline
\end{tabular}

variable recharge. Given the unknowns with the Thiem approach, the small elevation difference between the current mine pool and the Steve Level, and the complex physical controls on the flow system; the statement on page 40 by Wyman and Effner (2007) "seasonal conditions are not expected to result in any significant transient head buildup above the static water level" is questionable. It is well documented that in low permeability fractured crystalline rocks, seasonal recharge can cause large changes in groundwater levels (for example, Snow, 1972; Manning and Caine, 2007). The effects of seasonal transients in recharge on the mine pool elevation are perhaps the most poorly understood aspect of this problem.

4. Wyman and Effner (2007) report that, assuming a value of 3 inches per year for groundwater recharge and an annual average infiltration rate of $8.8 \mathrm{gpm}$ as derived from seasonal variations in mine pumping records, a "direct recharge capture area" of 56.8 acres for the "fully dewatered condition" in the mine is estimated. They further estimate a recharge capture area for the upper workings that is 9 acres, with a resultant $1.4 \mathrm{gpm}$ annual average infiltration rate. It can be inferred that Wyman and Effner (2007) distribute 3 inches per year over the reported capture areas to determine the flow rates to the mine using the dimensional equation:

$$
Q=\frac{\mathrm{L}^{3}}{\mathrm{~T}}=\frac{\mathrm{L}}{\mathrm{T}} \times \mathrm{L}^{2}
$$

where $Q=$ volumetric flow rate, $\mathrm{L}=$ length, and $\mathrm{T}=$ time. Thus, $\mathrm{L} / \mathrm{T}$ equates to the infiltration rate of precipitation and $\mathrm{L}^{2}$ equates to the area over which a specified amount of precipitation is distributed. Although these calculations can be successfully repeated using Equation 2 and the specified input values, they do not correspond to the mine inflow rates calculated using Equation 1 for similar radii of influence. Capture areas and values of $R$ do not necessarily need to be related, however, values of $Q$ to the mine are attributed to infiltration by Wyman and Effner (2007) and thus should be approximately the same using both methods. Estimates of capture areas assume vertical flow, yet there likely is lateral groundwater flow going into the mine, at depth, based on surface measurements of subhorizontal fracture networks compatible with tectonic deformation from Laramide compression and exhumation (Figures $\mathrm{C}$ and $\mathrm{D}$ ).

Wyman and Effner (2007) do not provide sensitivity analyses for the uncertain estimate of recharge and infiltration. Solving Equation 2 for $\mathrm{L}^{2}$, as a proxy for capture area and inputting the reported annual average infiltration rate of $8.8 \mathrm{gpm}$ and 1,3 , and 5 inches of precipitation per year, all viable values, the capture area to the "upper workings" is 169.9 acres, 56.6 acres, and 34.0 acres, respectively. Thus the estimate of the capture area is highly sensitive to infiltration estimates that are poorly constrained. Finally, the geometry of the capture area is poorly constrained, particularly for fractured and faulted rocks that could capture infiltration from areas outside of the regions mapped in Figure 20. The regions mapped in Figure 20 would require a significant amount of additional data to determine capture area with confidence.

\section{Subsection 5.2.3, Observed Rate of Mine Flooding, Pages 34-39}

1. On pages 36 and 37 (Figure 23), Wyman and Effner (2007) report on and show a plot of the volume of mine voids by level. They do not indicate how these data were derived, any assumptions, or any uncertainties associated with the data. For example, it is unknown if measurements of the shapes and heights of the various tunnels, winzes, raises, sizes and shapes of stopes and areas of collapse were included in the volume estimates.

2. Page 38 includes the statement "The plot of the water level in the mine versus time forms a smooth and predictable curve..." The curve has several irregularities that are likely because of transients and complexities of 
flow to and within the mine workings. Such transients have been noted in other mines that were allowed to flood, as reported in Adams and Younger (2001) and Younger and Robins (2002).

3. Although the "mine pool" may be close to an equilibrium or "static water level," the degree of imbalances between seasonal infiltration rates and bedrock drainage remains uncertain, particularly in this complex fractured and faulted aquifer. More recent water level data from the mine pool are presented in the Environmental Protection Plan by Whetstone Associates (2010). The 2010 data are referenced to the Steve Level at a reported elevation of $6,602.3 \mathrm{ft}$. The Steve Level is a critical benchmark as it is the primary haulage adit that connects the full mine workings to the surface. Thus, the Steve and adjacent Pierce adits are potential pathways for contaminated mine pool water to enter the local environment. At present (2010) these adits are hydraulically sealed with bulkheads (Wyman and Effner, 2007). Should the mine pool rise to the Steve Level or above, for example because of infiltration from several wet years in a row, springs and seeps of uranium-rich groundwater might emerge at the break in slope where the Steve, Pierce, and other adits were constructed. Other potential access points to mine pool water include the Black Forest adit seen in the field to the northwest of the Steve and Pierce, but little information was found on its extent or connection to the rest of the mine workings. The next higher, well-connected mine feature above the Steve Level is the Charlie Level at 6,721 $\mathrm{ft}$, and about $119 \mathrm{ft}$ above the Steve Level. Field observations indicate the Charlie is covered with colluvium or artificial fill. There is a ventilation shaft slightly above the Charlie at an approximate elevation of $6,769 \mathrm{ft}$. The "CV" Level at $6,791 \mathrm{ft}$ also appears to be covered. The next Levels include the Minnesota at 6,817 ft, the LBJ at 6,887 $\mathrm{ft}$, and Upper at 6,947 ft. The ventilation shaft, Charlie, CV, Minnesota, LBJ and Upper Levels are apparently not hydraulically sealed.

4. Insight and constraints are provided by the mine pool elevation data shown in Figures 21 and 22 of Wyman and Effner (2007) and the more recent data in Whetstone Associates (2010, Table 8-13). Table B, adapted from Whetstone Associates (2010, Table 8.13) with one correction, shows the most recent elevation fluctuations of the Schwartzwalder Mine pool from the period of October 2007 through July 2010 . The correction is for $7 / 1 / 10$, for which " $23.7 \mathrm{ft}$ below Steve" in Table 8.13 should read "14.4 ft below Steve." The rates of elevation change vary from a slow draining condition at a rate of $-0.0024 \mathrm{ft} / \mathrm{d}$ to a high filling condition at a rate slightly greater than 0.1 $\mathrm{ft} / \mathrm{d}$. The integrated mine pool elevation data indicate that the rate of groundwater drainage has been less than the rate of groundwater infiltration during the last 2.5 years. In addition, the seasonal transients from yearly springtime infiltration add significant quantities of quasi-permanent groundwater with continued increases in the elevation of the mine pool as of July 1, 2010, thus suggesting that rebound from the pre-mining elevation is incomplete.

If the reported time series data are representative of future changes in mine pool elevation, they can be used to provide some insight into if and when the mine pool might reach the Steve Level. Four flooding periods of distinctive seasonal infiltration or drainage drawn from the most recent data include: (1) October 29, 2007 to April 23, 2009 represents a period of drainage, (2) April 23, 2009 to August 12, 2009 represents a period of average springtime infiltration, (3) August 12, 2009 to April 1, 2010 represents a period of groundwater "base flow" and non-springtime infiltration, and (4) April 1, 2010 to July 1, 2010 represents a period of high springtime infiltration (Table B). Using combinations of these periods, four hypothetical scenarios can be simulated that account for variations and extremes in yearly infiltration and drainage. For each scenario, 0.75 of a year is simulated using either low infiltration or low drainage and the remaining 0.25 of the year with either average or high springtime infiltration. The total change in mine pool elevation for a simulated year is tallied using combinations of specified periods. The time it would take to reach the Steve Level is computed from the elevation on July 1, 2010 using the simulated rates for each scenario. Table B shows that under these four scenarios the mine pool could reach the Steve Level in about a year and one half if there were average infiltration for 0.25 of the year (Period 2) and groundwater "base flow" for 0.75 of the year (Period 3) or about Winter 2012. The mine pool would reach the Steve Level in about 7.3 years if there were high infiltration for 0.25 of the year (Period 4) and drainage for 0.75 of the year (Period 1) or about Fall 2017. Ultimately, the magnitude of seasonal precipitation and infiltration rate compared to the drainage rate will control when and if the mine pool water level will reach the Steve Level.

\section{Subsection 5.2.4, Projected Final Water Level, Pages 39-40}

Perhaps the most challenging aspect of estimating the final mine pool elevation is defining the head regime above and around the mine workings for which there are exceptionally little data. Hydraulic heads were not measured in the vicinity of the mine prior to mining and there are currently (2010) only three measurement points; MW11, the mine pool, and Ralston Creek (Figure G; modified from Wyman and Effner, 2007).

Although the original figure says "not to scale," the topographic profile was checked in relation to the locations of MW11 and Ralston Creek and these were found to be reasonably accurate. Groundwater hydraulic head data collected in 2010 are shown as light blue lines at the three measurement points; MW11 (about $100 \mathrm{ft}$ below ground surface, elevation $=7,299 \mathrm{ft})$, mine pool elevation below the Steve Level $(6,588 \mathrm{ft})$, and the elevation of Ralston Creek (6,552 ft). The 
Table B. Recent mine pool elevation data and projections of water levels from measured infill rates.

[Abbreviations: foot, ft; d, day; yr, year. Elevations are referenced to EGM 96. Notes: Steve elevation =6,602 ft. Observations from transducer in Steve Level reported in Revised Whetstone Associates, Environmental Protection Plan of 8/4/2010, Table 8-13, Page 8-30.]

\begin{tabular}{|c|c|c|c|c|c|c|c|c|c|}
\hline $\begin{array}{l}\text { Flooding } \\
\text { period }\end{array}$ & $\begin{array}{l}\text { Date } \\
\text { start }\end{array}$ & $\begin{array}{l}\text { Date } \\
\text { end }\end{array}$ & $\begin{array}{l}\text { Duration } \\
\text { (d) }\end{array}$ & $\begin{array}{c}\text { Water } \\
\text { elevation } \\
\text { (ft) start }\end{array}$ & $\begin{array}{c}\text { Water } \\
\text { elevation } \\
\text { (ft) end }\end{array}$ & $\begin{array}{c}\text { Water height } \\
\text { (ft below } \\
\text { Steve Level) } \\
\text { start }\end{array}$ & $\begin{array}{l}\text { Water height } \\
\text { (ft below } \\
\text { Steve Level) } \\
\text { end }\end{array}$ & $\begin{array}{c}\text { Change } \\
\text { in height } \\
\text { (ft) }\end{array}$ & $\begin{array}{c}\text { Rate of } \\
\text { change } \\
(\mathrm{ft} / \mathrm{d})\end{array}$ \\
\hline 2 & $4 / 23 / 09$ & 8/12/09 & 109 & $6,575.356$ & $6,578.536$ & 26.94 & 23.76 & 3.18 & 0.029 \\
\hline 4 & $4 / 1 / 10$ & $7 / 1 / 10$ & 90 & $6,578.669$ & $6,587.918$ & 23.63 & 14.38 & 9.25 & 0.1028 \\
\hline $\begin{array}{l}\text { Flooding } \\
\text { period }\end{array}$ & $\begin{array}{c}\text { Rate of } \\
\text { change } \\
(\mathrm{ft} / \mathrm{d})\end{array}$ & $\begin{array}{l}\text { Average } \\
\text { change } \\
\text { for } 90 \mathrm{~d} \\
\text { (ft) }\end{array}$ & $\begin{array}{c}\begin{array}{c}\text { Average } \\
\text { change } \\
\text { for }\end{array} \\
365-90 \\
=275 \mathrm{~d} \\
\text { (ft) }\end{array}$ & & $\begin{array}{l}\text { Scenario } 1 \\
\text { Average total } \\
1 \text { year change } \\
\text { Period } 2 \text { for } \\
90 \mathrm{~d}+ \\
\text { Period } 3 \text { for } \\
275 \mathrm{~d}(\mathrm{ft} / \mathrm{yr})\end{array}$ & $\begin{array}{c}\text { Scenario } 2 \\
\text { Average total } \\
1 \text { year change } \\
\text { Period } 4 \text { for } \\
90 \mathrm{~d}+ \\
\text { Period } 3 \text { for } \\
275 \mathrm{~d}(\mathrm{ft} / \mathrm{yr})\end{array}$ & $\begin{array}{c}\text { Scenario } 3 \\
\text { Average total } \\
1 \text { year change } \\
\text { Period } 2 \text { for } \\
90 \mathrm{~d}+ \\
\text { Period } 1 \text { for } \\
275 \mathrm{~d}(\mathrm{ft} / \mathrm{yr})\end{array}$ & $\begin{array}{c}\text { Scenario } 4 \\
\text { Average total } \\
1 \text { year change } \\
\text { Period } 4 \text { for } \\
90 \mathrm{~d}+ \\
\text { Period } 1 \text { for } \\
275 \mathrm{~d}(\mathrm{ft} / \mathrm{yr})\end{array}$ & $\begin{array}{l}\text { Projected } \\
\text { time for } \\
\text { mine pool } \\
\text { to Steve Level } \\
\text { from } 14.38 \mathrm{ft} \\
\text { on } 7 / 1 / 10 \\
\text { (years) }\end{array}$ \\
\hline 1 & -0.0024 & -0.22 & -0.67 & & 2.79 & 9.41 & & & $\begin{array}{l}5.16 \\
1.53\end{array}$ \\
\hline 2 & 0.029 & 2.63 & 8.02 & & & & 1.96 & 8.58 & $\begin{array}{l}7.35 \\
1.68\end{array}$ \\
\hline 3 & 0.0006 & 0.05 & 0.16 & & & & & & \\
\hline 4 & 0.1028 & 9.25 & 28.26 & & & & & & \\
\hline
\end{tabular}

$747 \mathrm{ft}$ elevation difference and the 2,597 ft horizontal distance between MW11 and Ralston Creek translate into a calculated hydraulic gradient of about 0.28 . This likely is an unstable water table configuration and the stable water table in the plane of the cross section in Figure $G$ is yet to be realized.

\section{Section 5.3, Evaluation of the Hydraulic Connection Between Ralston Creek and the Mine, Pages 41-43}

This section provides evidence that a 'strong' connection between the mine pool and Ralston Creek is not indicated, but the evidence is inadequate to rule out a weak connection. The evidence for the lack of a connection includes the observation that mine dewatering did not cause Ralston Creek to dry up; that the stable isotopic composition of the mine pool water plot closer to the meteoric water line than the data for the single stream sample presented; and that tritium data were not definitive. Indications of a nonexistent to weak hydraulic connection between the mine pool and Ralston Creek during dewatering does not preclude a stronger connection since the mine pool has risen above the elevation of the creek, particularly because connecting shallow pathways between the mine and the stream may have drained during initial mine dewatering. It is worth noting that a single sample from Ralston Creek is not adequate to characterize the seasonal range of $\delta^{18} \mathrm{O}$ along the meteoric water line for the area of Ralston Creek (for example, snowmelt may be as depleted in $\delta^{18} \mathrm{O}$ as the 700 level sample, but cannot be evaluated without additional analyses). Wyman and Effner (2007) state that "Waters that differ significantly from the isotopic compositions observed for the meteoric water are generally interpreted to have had long residence times as groundwater". As described in Clark and Fritz (1997), oxygen and deuterium isotope compositions that fall below the local meteoric water line are usually because of water evaporation before recharge, not because of longer residence times. 


\section{Section 6.5, Ralston Creek Water Quality, Pages 52-90}

1. The first paragraph in this section covers all of the potential sources of water and any constituents in them, but the data and interpretation that follow do not address the relative contributions from each source. These contributions are the central issue and probably cannot be determined using concentration data alone.

2. In the unnumbered table on page 52 and in Table 24, uranium is reported as milligrams per liter $(\mathrm{mg} / \mathrm{L})$; the same values are given in Appendix F with uranium reported as picocuries per liter $(\mathrm{pCi} / \mathrm{L})$. Inconsistencies in reporting of units in the report make interpretation of the data difficult.

\section{Subsection 6.5.2, Water Quality After Turning off the Sumps and Water Treatment Plant, Page 53}

The data presented in this subsection indicate a "first flush" phenomenon in Ralston Creek. This "first flush" is the result of rock weathering in the unsaturated zone. Relatively soluble constituents are preferentially dissolved when the water table first rises. However, the long-term effects of the contaminated surficial deposits on water quality in Ralston Creek are not well understood. Figures 31 and 32 show the "first flush" and a strong seasonal effect on dissolved constituents at SW-BPL, a long-term Ralston Creek surface water sampling just below the mine site. Figure 33 indicates that dissolved uranium concentrations in the creek increase after the sumps were shut down. Based on Table 24, the median dissolved uranium concentration increased from SW-AWD above the mine site $(0.0025 \mathrm{mg} / \mathrm{L})$ to $\mathrm{SW}-\mathrm{BPL}(0.03135 \mathrm{mg} / \mathrm{L})$.

Again based on Table 24, the median uranium concentration of the treatment discharge (SW-DIS001) is $0.0055 \mathrm{mg} / \mathrm{L} \mathrm{com-}$ pared with a median uranium concentration of $0.0032 \mathrm{mg} / \mathrm{L}$ below the discharge point (SW-BDIS) indicating no real effect from the treatment discharge on uranium concentrations in Ralston Creek. All of the major increases in uranium concentrations in Ralston Creek occurred at the mine site or downgradient, particularly once the sumps were turned off in June 2002.

Upgradient concentrations of dissolved uranium at 0.002 to $0.004 \mathrm{mg} / \mathrm{L}$ are consistent with recent U.S. Geological Survey measurements. While the sumps were operating, uranium concentrations at SW-BPL were about $0.008 \mathrm{mg} / \mathrm{L}$ and the furthest downgradient (SW-LLHG) concentration was about $0.01 \mathrm{mg} / \mathrm{L}$. Concentrations of 0.008 to $0.01 \mathrm{mg} / \mathrm{L}$ approximate the baseline drainage from the mineralized rocks surrounding the Schwartzwalder Mine. Once the sumps were turned off, the median uranium concentration at SW-BPL increased to $0.05 \mathrm{mg} / \mathrm{L}$ and SW-LLHG uranium concentration also increased to about $0.05 \mathrm{mg} / \mathrm{L}$. This suggests a 0.04 $\mathrm{mg} / \mathrm{L}$ uranium concentration increase because of mine effect, which could include drainage from the contaminated surficial materials, natural runoff from the mineralized area, and a component of mine pool water. All of these sources would have been collected prior to the sump and water treatment shut down. In Appendix G of Wyman and Effner (2007), a short sump shut down coincided with a $0.0009 \mathrm{mg} / \mathrm{L}$ uranium concentration increase in Ralston Creek because of "loading from the alluvium."

\section{Section 7.2, Alluvial Water Quality, Page 94}

This section discusses the aqueous geochemistry of the alluvial groundwater at the mine site. Uranium and molybdenum are detected and the highest dissolved uranium concentrations in 2002-2003 would appear to be because of the sump shut down. However, the possible sources of such uranium concentrations and chemical processes that facilitate dissolution and transport of oxyanions are not adequately discussed. It is stated that the "the groundwater in the mine and in the alluvium have distinct geochemical signatures" but specific chemical differences are not provided. For example, the groundwater in the alluvium appears to be a "diluted version" of mine pool water given the similar source rocks, but no data indicating a "distinct geochemical signature" are presented.

\section{Section 7.5, Shallow Bedrock Water Quality, Page 119}

Compared to values in Ralston Creek above the mine site, relatively high dissolved uranium concentrations were measured in MW11. The average dissolved uranium concentration in MW11 was $0.29 \mathrm{mg} / \mathrm{L}$ with a median concentration of $0.033 \mathrm{mg} / \mathrm{L}$ for 10 samples collected between February 1999 and July 2001. These data suggest that groundwater above the mine is within the region of effect of the hydrothermal uranium deposit. However, the variability of uranium concentrations in MW11 is quite large (0.007 to $2.63 \mathrm{mg} / \mathrm{L})$. New data from MW11 in November 2010 indicated a uranium concentration of $0.00037 \mathrm{mg} / \mathrm{L}$ (without purging). Collection of additional samples from MW11 and more background groundwater quality data are suggested for future studies.

\section{Section 7.6.3, Water Quality in the Reflooded Mine, Pages 127-139}

The text in this section indicates that 115 samples were collected through June 2007 and complete analytical analyses are presented in Appendix F of Wyman and Effner (2007). Only 3 of these 115 samples were listed (under SHAFT) in Appendix F. Table 37 on page 129 is not adequately linked to Appendix F and information such as sample location, time of sampling, and depth of sampling are not provided. The 3 "SHAFT" samples listed in Appendix F have relatively uniform dissolved uranium concentrations of about $45 \mathrm{pCi} / \mathrm{L}$, however, units of $\mathrm{mg} / \mathrm{L}$ seem more likely based on Table 37. 


\section{Subsection 7.6.3.1, Evaluation of Mine Water Quality with Depth, Page 130}

1. The mine pool was sampled at various depths and intervals over time. However, key constituents such as dissolved uranium are not plotted as a function of depth. To understand the full scope of potential chemical contamination from the mine pool as a source, it is critical to know if there is chemical stratification of various constituents and how stratification might be related to parameters such as reduction potential (Eh), $\mathrm{pH}$, and temperature. This subsection does not elaborate on the concentrations of toxic constituents with depth in the mine pool water. If there is chemical stratification then samples taken only from the near surface of the mine pool in the Steve Adit may not be representative of the chemistry at depth.

2. It is noted on page 130 that there are "moderately oxidizing conditions at depths of several hundred feet below the surface of the pool." This is consistent with high concentrations of dissolved uranium at these depths, but uranium concentration is never presented and the depth of the SHAFT sample in Appendix F is not listed.

\section{Subsection 7.6.3.2, Evaluation of Chemical Trends in Mine Water as a Function of Time, Page 130}

In item 13 it is noted that uranium concentrations in mine water increased from about $4 \mathrm{mg} / \mathrm{L}$ to about $59.5 \mathrm{mg} / \mathrm{L}$ from initial mine flooding in May 2000 to October 2002. From 2003 to 2007 the concentration was said to have "steadily decreased" to about $45 \mathrm{mg} / \mathrm{L}$ (about a 25 percent decrease over about four years). Data from December 2009 show a lower concentration of $35 \mathrm{mg} / \mathrm{L}$. There are little data on how "steady" these changes are and they may only capture what is happening in the shallowest part of the mine pool.

\section{Section 8, Characterization of Waste Rock and Fill, Page 140}

Bottle roll leaching tests are mentioned but no data are presented. Such data would be useful for determining the relative leachability of constituents that might be diagnostic of sources in the waste rock and fill.

\section{Section 9, Impact Analysis, Subsection Mine Water Chemistry, Page 142-151}

\author{
Subsection 9.4.1.2, Evaluation of Precipitation \\ and Dissolution Reactions Controlling Mine \\ Water Chemistry
}

\subsubsection{1, Upper Mine Water Speciation, Page 148}

A charge imbalance of -46.77 percent is quite large for doing meaningful mineral/solution equilibria calculations on the sample used. Resulting errors in calculated mineral saturation indices could be quite large.

\subsubsection{3, Reflooded Mine Water Speciation, Page 149}

Wyman and Effner (2007) state that " $\mathrm{CO}_{2}$ gas is oversaturated in the mine water." However, the dissolved $\mathrm{CO}_{2}$ concentrations are reasonable for groundwater after contact with soil gas $\mathrm{CO}_{2}$. In addition, $\mathrm{CO}_{2}$ does not "precipitate when oversaturated" like a mineral would, but degasses upon drops in pressure or when the water is exposed to air (Clark and Fritz, 1997).

\subsubsection{4, Modified Reflooded Mine Water Speciation, Page 150}

Geochemical modeling under a lower assumed Eh is significant because lower Eh could cause precipitation of dissolved uranium in the mine pool. Such precipitation is presently unlikely because of the extremely high concentrations of uranium observed in the mine pool.

\section{Recent U.S. Geological Survey Analyses of Aqueous Geochemistry at the Schwartzwalder Mine Site}

\section{Methods}

Mine pool, well, sump, and stream water samples were collected in the vicinity of the Schwartzwalder Mine site at the locations shown on Figure E on November 19, 2010. All 
water samples were collected through plastic tubing connected to a peristaltic pump. Water was filtered in-line using a 0.45 $\mu \mathrm{m}$ capsule filter. Typically about $1 \mathrm{~L}$ samples were collected directly at the water source, except for MW11. Groundwater from MW11 was collected via a plastic bailer, which only collected water near the top of the water column within the well (time, equipment, and access did not allow for well purging). The bailer sample was placed in a 1 liter (L) plastic bottle and then filtered. Specific conductance, temperature, $\mathrm{pH}$, and dissolved oxygen were measured at the time of collection with standard meters. Alkalinity measurements were completed in the field using a Hach digital titration kit. All water data, along with sample descriptions and locations are included in Table C.

Each sample was split into even aliquots to provide samples for (1) dissolved major and minor cations and sulfate, (2) dissolved major anions, (3) iron pairs $\left(\mathrm{Fe}^{2+} / \mathrm{Fe}^{3+}\right),(4)$ uranium isotopes $\left({ }^{234} \mathrm{U} /{ }^{238} \mathrm{U}\right),(5)$ sulfur isotopes $\left(\delta^{34} \mathrm{~S}\right)$, and (6) carbon isotopes $\left(\delta^{13} C\right)$. Samples for dissolved major and minor cations and sulfate and uranium isotopes were acidified to a $\mathrm{pH}$ less than 2 with ultra pure nitric acid. Water samples for major anions were refrigerated for preservation. The iron pair samples were acidified to a $\mathrm{pH}$ less than 2 using ultra pure hydrochloric acid. Samples for sulfur isotopes were preserved with 2 drops of nitric acid and carbon isotope samples were preserved with 2 drops of copper chloride, both to decrease bacterial activity. Analyses for major and minor cations, major anions, iron pairs, and sulfur isotopes were completed at the U.S. Geological Survey Mineral Resources Laboratory (Denver, Colo.). Major and minor cations plus sulfate were determined by inductively coupled plasma-mass spectrometry (ICP-MS, Lamothe and others, 2002). Anion analyses were determined by ion chromatography (IC, Theodorakos and others, 2002). Based on analyses of known standards, error in the ICP-MS and IC data is less than 5-10 percent. Iron pairs were analyzed using the ferrozine method for iron species with errors of generally less than \pm 5 percent (Bangthanh To and others, 1999).

Sulfur isotope data were obtained by precipitating dissolved sulfate as barite by adding $\mathrm{BaCl}_{2}$ to each sample. The barite was recovered by filtration using 0.45 micron membranes and then dried at $90{ }^{\circ} \mathrm{C}$. Filtrates were weighed into tin capsules along with a flux (reagent grade $\mathrm{V}_{2} \mathrm{O}_{5}$ ), and the capsules were combusted in an elemental analyzer to form $\mathrm{SO}_{2}$ gas, which then flowed directly to an Micromass Optima mass spectrometer for isotope measurement by isotope ratio monitoring (modification of method of Geisemann and others, 1995). Isotopic compositions are reported in delta-notation, in units of per mil, relative to Vienna Canon Diablo Troilite (VCDT). Duplicate analyses agreed to within 0.3 per mil or better.

Uranium isotopic analyses $\left({ }^{234} \mathrm{U} /{ }^{238} \mathrm{U}\right)$ were completed at Northern Arizona University (NAU), Department of Chemistry and Biochemistry, Flagstaff, Ariz. Uranium activity ratios were acquired with a quadrupole ICP-MS (Thermo X Series II) equipped with an APEX HF sample introduction system and concentric FEP Teflon nebulizer. Samples with lower uranium concentrations were preconcentrated. Dissolved uranium concentrations were measured by a VG Axiom sector-field ICP-MS unit. Error bounds of one standard deviation are listed with the results.

Carbon isotopes were analyzed at the Laboratory of Isotope Geochemistry at the University of Arizona, Tucson, Ariz. $\delta^{13} \mathrm{C}$ of dissolved inorganic carbon (DIC) was measured on a continuous-flow gas-ratio mass spectrometer (ThermoQuest Finnigan Delta PlusXL) coupled with a Gasbench automated sampler (also manufactured by Finnigan). Samples were reacted for more than 1 hour with phosphoric acid at room temperature in Exetainer vials previously flushed with He gas. Standardization is based on NBS-19 and NBS-18 and precision was $\pm 0.30 \%$ ( 1 sigma). One equipment blank (EB-1) was collected to identify any contamination during sampling (no significant contamination was found).

\section{Previous Data}

Previous work at the Schwartzwalder Mine demonstrated the difference in stream water quality with and without the sumps and treatment plant operating (Figure H; Wyman and Effner, 2007). Mine dewatering and effluent treatment (for uranium only) continued through May 2000 and the series of four sumps operated from 1990 through June 2002. Sump 1 continued to recirculate groundwater to Sump 4 without treatment as a hydraulic barrier until April 2008. During the effluent discharge period through June 2002, increases in TDS, sulfate, specific conductance, magnesium, sodium, molybdenum, and alkalinity are apparent (Figure 28 in Wyman and Effner, 2007 for December 1998 data) while the uranium concentration varied within a narrow range of $0.003 \mathrm{mg} / \mathrm{L}$ upstream from the mine site to $0.006 \mathrm{mg} / \mathrm{L}$ downstream (Wyman and Effner, 2007). Geochemical data for Ralston Creek are available through March 2010 (Whetstone Associates, 2010).

Dissolved uranium concentrations are plotted for four stream locations on December 17, 1998; December 16, 2003; December 28, 2007; and December 11, 2009 (Figure H2). December dates are used in these plots to consistently show data collected during stream base flow conditions. The uranium concentration in Ralston Creek on December 17, 1998 was within the range of $0.003 \mathrm{mg} / \mathrm{L}$ to $0.006 \mathrm{mg} / \mathrm{L}$ (Wyman and Effner, $2007)$ for the period (1990-2002) with sumps and water treatment operational (Figure H2). In December 2003, the mine pool was still below stream level but the sumps and treatment were not operational, except for recirculation in Sump 1 to Sump 4. Uranium concentrations above the site remained low (less than $0.010 \mathrm{mg} / \mathrm{L}$ ) but they increased below the site to a range of 0.080 to $0.140 \mathrm{mg} / \mathrm{L}$.

The mine pool elevation measured from the Steve Level had risen above the elevation of Ralston Creek at SW-OS or about 6,552 ft on approximately March 15, 2007 (Whetstone Associates, 2010 indicates a date of February 2007 with an elevation of 6,540 ft) and the sumps remained shut down, except for recirculation in Sump 1 to Sump 4. The pattern 
Table C. Schwartzwalder Mine site aqueous elemental chemistry of surface and groundwater.

[USGS Job Number: MRP-11390. All data from inductively coupled plasma-mass spectrometry (ICP-MS) except when noted IC for ion chromatography. Free air radioactivity near the ground surface at each sample location site (Site Rad) was measured using a handheld scintillation counter in units of microroentgens per hour (mR/hr). Duplicate analyses were run for dissolved uranium concentrations.

Horizontal coordinates are referenced to WGS 84 and vertical coordinates to EGM 96. Samples collected and processed November 2010 by R.H. Johnson and J.S. Caine, U.S. Geological Survey. Abbreviations: latitude, LAT; longitude, LON; decimal degrees, dd; foot, ft; microroentgens per hour, $\mathrm{mR} / \mathrm{hr}$; microsiemens per centimeter, $\mu \mathrm{S} / \mathrm{cm}$; degrees Celsius, ${ }^{\circ} \mathrm{C}$.]

\begin{tabular}{|c|c|c|c|c|c|c|c|c|c|c|c|c|c|}
\hline $\begin{array}{c}\text { Field } \\
\text { number }\end{array}$ & $\begin{array}{c}\text { Sample } \\
\text { description }\end{array}$ & $\begin{array}{l}\text { Sample } \\
\text { type }\end{array}$ & LAT (dd) & LON (dd) & $\begin{array}{c}\text { Elevation } \\
\text { (ft) }\end{array}$ & $\begin{array}{c}\text { Site } \\
\text { Rad } \\
\text { (mR/hr) }\end{array}$ & $\begin{array}{l}\text { Conduc- } \\
\text { tance } \\
\text { ( } \mu \mathrm{S} / \mathrm{cm})\end{array}$ & $\begin{array}{l}\text { Temp- } \\
\text { erature } \\
\quad \text { oC }\end{array}$ & $\mathrm{pH}$ & $\begin{array}{c}\text { Alkalinity } \\
\text { (mg/L } \\
\left.\mathrm{CaCO}_{3}\right)\end{array}$ & $\begin{array}{c}\text { Dissolved } \\
\text { oxygen } \\
\text { (mg/L) }\end{array}$ & $\begin{array}{l}{ }^{13} \mathrm{C} \\
(\%)\end{array}$ & $\begin{array}{c}{ }^{13} \mathrm{C} \\
\text { error } \\
\text { as } \\
1 \sigma \\
(\%) \\
\end{array}$ \\
\hline $1119101 \mathrm{C}$ & Mine Pool & mine pool & 39.84499 & 105.28016 & 6602 & 36 & 3270 & 12.5 & 6.95 & 185 & 2.10 & -4.0 & 0.3 \\
\hline $1119102 \mathrm{C}$ & MW11 & well & 39.84118 & 105.28642 & 7398 & 9 & 141.1 & 8.7 & 5.20 & 8 & 1.15 & -12.3 & 0.3 \\
\hline $1119103 \mathrm{C}$ & Sump 1 & sump & 39.84414 & 105.27744 & 6542 & 40 & 1110 & 8.6 & 6.22 & 63 & 3.37 & -1.8 & 0.3 \\
\hline $1119104 \mathrm{C}$ & $\begin{array}{l}\text { Stream } \\
\quad \text { Sump } 1\end{array}$ & stream & 39.84424 & 105.27721 & 6538 & 39 & 507 & 6.2 & 6.70 & 34 & 6.03 & -5.3 & 0.3 \\
\hline $1119105 \mathrm{C}$ & $\begin{array}{l}\text { Stream } \\
\text { Above }\end{array}$ & stream & 39.85163 & 105.28861 & 6601 & 15 & 315 & 3.7 & 6.96 & 43 & 6.42 & -4.8 & 0.3 \\
\hline $1119106 \mathrm{C}$ & $\begin{array}{l}\text { Stream } \\
\text { Below }\end{array}$ & stream & 39.83738 & 105.27295 & 6401 & 30 & 557 & 5.6 & 7.96 & 70 & 6.01 & -5.6 & 0.3 \\
\hline EB1 & Blank & NA & NA & NA & NA & NA & & & & & & & \\
\hline $\begin{array}{c}\text { Sample } \\
\text { description }\end{array}$ & ${ }^{234} \mathrm{U} /{ }^{238} \mathrm{U}$ & $\begin{array}{c}{ }^{234} \mathrm{U} /{ }^{238} \mathrm{U} \\
\text { error as } \\
1 \sigma\end{array}$ & $\begin{array}{c}\delta^{34} \mathbf{S} \\
\% 0\end{array}$ & $\begin{array}{c}\text { Duplicate } \\
\delta^{34} \mathrm{~S} \\
\%\end{array}$ & $\underset{(\mu \mathrm{g} / \mathrm{L})}{\mathrm{Ag}}$ & $\begin{array}{c}\text { Al } \\
(\mu \mathrm{g} / \mathrm{L})\end{array}$ & $\begin{array}{c}\text { As } \\
(\mu \mathrm{g} / \mathrm{L})\end{array}$ & $\begin{array}{c}\mathrm{Ba} \\
(\mu \mathrm{g} / \mathrm{L})\end{array}$ & $\begin{array}{c}\mathrm{Be} \\
(\mu \mathrm{g} / \mathrm{L})\end{array}$ & $\underset{(\mu \mathrm{g} / \mathrm{L})}{\mathrm{Bi}}$ & $\begin{array}{c}\mathrm{Ca} \\
(\mathrm{mg} / \mathrm{L})\end{array}$ & $\underset{(\mu \mathrm{g} / \mathrm{L})}{\mathrm{Cd}}$ & $\begin{array}{c}\mathrm{Ce} \\
(\mu \mathrm{g} / \mathrm{L})\end{array}$ \\
\hline Mine Pool & 1.138 & 0.005 & -3.3 & -3.4 & $<1$ & $<2$ & 13.9 & 17.9 & $<0.05$ & $<0.2$ & 433 & 2.6 & 0.07 \\
\hline MW11 & 1.76 & 0.04 & 4.1 & 3.8 & $<1$ & $<2$ & $<1$ & 14.3 & $<0.05$ & $<0.2$ & 10.9 & $<0.02$ & $<0.01$ \\
\hline Sump 1 & 1.119 & 0.005 & -2.7 & -2.8 & $<1$ & $<2$ & $<1$ & 59.7 & $<0.05$ & $<0.2$ & 162 & 0.33 & 0.01 \\
\hline $\begin{array}{l}\text { Stream @ } \\
\text { Sump 1 }\end{array}$ & 1.132 & 0.013 & -1.2 & -1.3 & $<1$ & $<2$ & $<1$ & 60.1 & $<0.05$ & $<0.2$ & 68.2 & 0.04 & 0.01 \\
\hline Stream Above & 1.57 & 0.03 & 8.9 & 8.7 & $<1$ & $<2$ & $<1$ & 55 & $<0.05$ & $<0.2$ & 35.8 & $<0.02$ & 0.01 \\
\hline Stream Below & 1.136 & 0.002 & -0.3 & -0.5 & $<1$ & $<2$ & $<1$ & 68.4 & $<0.05$ & $<0.2$ & 67.7 & 0.03 & $<0.01$ \\
\hline $\begin{array}{l}\text { Equipment } \\
\text { Blank }\end{array}$ & & & & & $<1$ & $<2$ & $<1$ & $<0.2$ & $<0.05$ & $<0.2$ & $<0.2$ & $<0.02$ & $<0.01$ \\
\hline $\begin{array}{c}\text { Sample } \\
\text { description }\end{array}$ & $\begin{array}{c}\text { Co } \\
(\mu \mathrm{g} / \mathrm{L})\end{array}$ & $\underset{(\mu \mathrm{g} / \mathrm{L})}{\mathrm{Cr}}$ & $\begin{array}{c}\text { Cs } \\
(\mu \mathrm{g} / \mathrm{L})\end{array}$ & $\underset{(\mu \mathrm{g} / \mathrm{L})}{\mathrm{Cu}}$ & $\begin{array}{c}\text { Dy } \\
(\mu \mathrm{g} / \mathrm{L})\end{array}$ & $\begin{array}{c}\mathrm{Er} \\
(\mu \mathrm{g} / \mathrm{L})\end{array}$ & $\underset{(\mu \mathrm{g} / \mathrm{L})}{\mathrm{Eu}}$ & $\begin{array}{c}\mathrm{Fe} \\
(\mu \mathrm{g} / \mathrm{L})\end{array}$ & $\begin{array}{c}\text { Total Fe } \\
(\mu \mathrm{g} / \mathrm{L})\end{array}$ & $\begin{array}{c}\mathrm{Fe}^{2+} \\
(\mu \mathrm{g} / \mathrm{L})\end{array}$ & $\begin{array}{c}\mathrm{Fe}^{3+} \\
(\mu \mathrm{g} / \mathrm{L})\end{array}$ & $\begin{array}{c}\text { Ga } \\
(\mu \mathrm{g} / \mathrm{L})\end{array}$ & $\begin{array}{c}\mathrm{Gd} / \mathrm{P} \\
(\mu \mathrm{g} / \mathrm{L})\end{array}$ \\
\hline Mine Pool & 20.7 & 11.1 & 4.4 & 2.4 & 0.006 & $<0.005$ & $<0.005$ & 3720 & 3930 & 3888 & 41 & 0.1 & 0.007 \\
\hline MW11 & $<0.02$ & 2.3 & $<0.02$ & 0.6 & $<0.005$ & $<0.005$ & $<0.005$ & $<50$ & $<5$ & $<5$ & $<5$ & $<0.05$ & $<0.005$ \\
\hline Sump 1 & $<0.02$ & 5.8 & 0.21 & 1.8 & 0.006 & 0.005 & $<0.005$ & $<50$ & 18.0 & 3.7 & 14.4 & $<0.05$ & 0.01 \\
\hline $\begin{array}{l}\text { Stream @ } \\
\text { Sump } 1\end{array}$ & $<0.02$ & 3 & 0.02 & 0.75 & $<0.005$ & 0.005 & $<0.005$ & $<50$ & 8.8 & 5.7 & 3.1 & $<0.05$ & 0.005 \\
\hline Stream Above & $<0.02$ & 2.2 & $<0.02$ & 0.59 & $<0.005$ & $<0.005$ & 0.005 & $<50$ & 12.0 & 12.0 & 0.0 & $<0.05$ & $<0.005$ \\
\hline Stream Below & $<0.02$ & 3 & 0.03 & 0.67 & 0.005 & $<0.005$ & 0.005 & $<50$ & 19.0 & 9.9 & 9.3 & $<0.05$ & 0.009 \\
\hline $\begin{array}{c}\text { Equipment } \\
\text { Blank }\end{array}$ & $<0.02$ & $<1$ & $<0.02$ & $<0.5$ & $<0.005$ & $<0.005$ & $<0.005$ & $<50$ & & & & $<0.05$ & $<0.005$ \\
\hline
\end{tabular}


Table C. Schwartzwalder Mine site aqueous elemental chemistry of surface and groundwater._Continued

[USGS Job Number: MRP-11390. All data from inductively coupled plasma-mass spectrometry (ICP-MS) except when noted IC for ion chromatography. Free air radioactivity near the ground surface at each sample location site (Site Rad) was measured using a handheld scintillation counter in units of microroentgens per hour (mR/hr). Duplicate analyses were run for dissolved uranium concentrations.

Horizontal coordinates are referenced to WGS 84 and vertical coordinates to EGM 96. Samples collected and processed November 2010 by R.H. Johnson and J.S. Caine, U.S. Geological Survey. Abbreviations: latitude, LAT; longitude, LON; decimal degrees, dd; foot, ft; microroentgens per hour, $\mathrm{mR} / \mathrm{hr}$; microsiemens per centimeter, $\mu \mathrm{S} / \mathrm{cm}$; degrees Celsius, ${ }^{\circ} \mathrm{C}$.]

\begin{tabular}{|c|c|c|c|c|c|c|c|c|c|c|c|c|c|}
\hline $\begin{array}{c}\text { Sample } \\
\text { description }\end{array}$ & $\begin{array}{c}\text { Ho } \\
(\mu \mathrm{g} / \mathrm{L})\end{array}$ & $\begin{array}{c}\mathrm{K} \\
\text { (mg/L) }\end{array}$ & $\begin{array}{c}\mathrm{La} \\
(\mu \mathrm{g} / \mathrm{L})\end{array}$ & $\begin{array}{c}\mathrm{Li} \\
(\mu \mathrm{g} / \mathrm{L})\end{array}$ & $\underset{(m g / L)}{M g}$ & $\begin{array}{c}M n \\
(\mu \mathrm{g} / \mathrm{L})\end{array}$ & 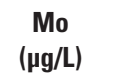 & $\begin{array}{c}\mathrm{Na} \\
(\mathrm{mg} / \mathrm{L})\end{array}$ & $\begin{array}{c}\mathrm{Nb} \\
(\mu \mathrm{g} / \mathrm{L})\end{array}$ & $\begin{array}{c}\underset{N d}{N} \\
(\mu g / L)\end{array}$ & $\underset{(\mu \mathrm{g} / \mathrm{L})}{\mathrm{Ni}}$ & $\begin{array}{c}P \\
(\mathrm{mg} / \mathrm{L})\end{array}$ & $\begin{array}{c}\mathrm{Pb} \\
(\mu \mathrm{g} / \mathrm{L})\end{array}$ \\
\hline Mine Pool & $<0.005$ & 24.5 & 0.08 & 143 & 274 & 5050 & 1400 & 174 & $<0.2$ & 0.02 & 22.2 & 0.07 & $<0.05$ \\
\hline MW11 & $<0.005$ & 3 & $<0.01$ & 11.2 & 4.1 & 42.5 & $<2$ & 14.5 & $<0.2$ & $<0.01$ & $<0.4$ & 0.2 & $<0.05$ \\
\hline Sump 1 & $<0.005$ & 7.4 & 0.07 & 27.6 & 72.4 & 7.1 & 52.4 & 46.8 & $<0.2$ & 0.03 & $<0.4$ & 0.03 & $<0.05$ \\
\hline $\begin{array}{l}\text { Stream @ } \\
\text { Sump 1 }\end{array}$ & $<0.005$ & 3 & 0.03 & 9.9 & 25.8 & 3.3 & 11.4 & 24.4 & $<0.2$ & 0.03 & $<0.4$ & $<0.01$ & $<0.05$ \\
\hline Stream Above & $<0.005$ & 1.7 & 0.01 & 3.8 & 9.9 & 3.2 & $<2$ & 16.9 & $<0.2$ & 0.02 & $<0.4$ & $<0.01$ & $<0.05$ \\
\hline Stream Below & $<0.005$ & 3.2 & 0.01 & 13 & 26.5 & 9.4 & 12 & 30.6 & $<0.2$ & 0.01 & $<0.4$ & 0.01 & $<0.05$ \\
\hline $\begin{array}{c}\text { Equipment } \\
\text { Blank }\end{array}$ & $<0.005$ & $<0.03$ & $<0.01$ & 0.6 & $<0.01$ & $<0.2$ & $<2$ & $<0.01$ & $<0.2$ & $<0.01$ & $<0.4$ & $<0.01$ & $<0.05$ \\
\hline $\begin{array}{c}\text { Sample } \\
\text { description }\end{array}$ & $\begin{array}{c}\mathrm{Pr} \\
(\mu \mathrm{g} / \mathrm{L})\end{array}$ & $\begin{array}{c}\mathbf{R b} \\
(\mu \mathrm{g} / \mathrm{L})\end{array}$ & $\underset{(\mu \mathrm{g} / \mathrm{L})}{\mathrm{Sb}}$ & $\begin{array}{c}\mathrm{Sc} \\
(\mu \mathrm{g} / \mathrm{L})\end{array}$ & $\begin{array}{c}\mathrm{Se} \\
(\mu \mathrm{g} / \mathrm{L})\end{array}$ & $\underset{(\mathrm{mg} / \mathrm{L})}{\mathrm{SiO}_{2}}$ & $\begin{array}{c}\mathrm{Sm} \\
(\mu \mathrm{g} / \mathrm{L})\end{array}$ & $\underset{\text { (mg/L) }}{\mathrm{SO}_{4}}$ & $\begin{array}{c}\mathrm{Sr} \\
(\mu \mathrm{g} / \mathrm{L})\end{array}$ & $\begin{array}{c}\mathrm{Ta} \\
(\mu \mathrm{g} / \mathrm{L})\end{array}$ & $\begin{array}{c}\mathrm{Tb} / \mathrm{P} \\
(\mu \mathrm{g} / \mathrm{L})\end{array}$ & $\begin{array}{c}\text { Th } \\
(\mu g / L)\end{array}$ & $\underset{(\mu \mathrm{g} / \mathrm{L})}{\mathrm{Ti}}$ \\
\hline Mine Pool & $<0.01$ & 46.2 & 0.5 & 1.3 & $<1$ & 16 & $<0.01$ & 2000 & 4000 & 0.05 & $<0.005$ & 251 & 23.5 \\
\hline MW11 & $<0.01$ & 0.68 & $<0.3$ & 1.6 & $<1$ & 20 & $<0.01$ & 22 & 64 & 0.04 & $<0.005$ & $<0.2$ & $<0.5$ \\
\hline Sump 1 & $<0.01$ & 5 & $<0.3$ & 1.3 & 1.1 & 18 & $<0.01$ & 520 & 769 & 0.03 & $<0.005$ & 23.2 & 6.6 \\
\hline $\begin{array}{l}\text { Stream @ } \\
\text { Sump 1 }\end{array}$ & $<0.01$ & 1.3 & $<0.3$ & 1.3 & $<1$ & 19 & $<0.01$ & 150 & 364 & 0.03 & $<0.005$ & 3.75 & 1.8 \\
\hline Stream Above & $<0.01$ & 0.34 & $<0.3$ & 1.2 & $<1$ & 19 & $<0.01$ & 22 & 220 & 0.03 & $<0.005$ & $<0.2$ & $<0.5$ \\
\hline Stream Below & $<0.01$ & 1.4 & $<0.3$ & 1.3 & $<1$ & 19 & $<0.01$ & 150 & 371 & 0.03 & $<0.005$ & 2.53 & 1.9 \\
\hline $\begin{array}{c}\text { Equipment } \\
\text { Blank }\end{array}$ & $<0.01$ & $<0.01$ & $<0.3$ & $<0.6$ & $<1$ & $<0.2$ & $<0.01$ & 3.1 & $<0.5$ & 0.04 & $<0.005$ & $<0.2$ & $<0.5$ \\
\hline $\begin{array}{c}\text { Sample } \\
\text { description }\end{array}$ & $\begin{array}{c}\mathrm{TI} \\
(\mu \mathrm{g} / \mathrm{L})\end{array}$ & $\underset{(\mu \mathrm{g} / \mathrm{L})}{\mathrm{Tm}}$ & $\underset{(\mu \mathrm{g} / \mathrm{L})}{\mathbf{U}}$ & $\begin{array}{c}\text { Duplicate } \\
\mathbf{U} \\
(\mu \mathrm{g} / \mathrm{L})\end{array}$ & $\begin{array}{c}\text { U error as } \\
1 \sigma \\
\text { U Ketterer }\end{array}$ & $\underset{(\mu \mathrm{g} / \mathrm{L})}{V}$ & $\underset{(\mu \mathrm{g} / \mathrm{L})}{W}$ & $\begin{array}{c}Y \\
(\mu \mathrm{g} / \mathrm{L})\end{array}$ & $\begin{array}{c}Y b \\
(\mu g / L)\end{array}$ & $\begin{array}{c}\mathrm{Zn} \\
(\mu \mathrm{g} / \mathrm{L})\end{array}$ & $\begin{array}{c}\mathrm{IC} \\
\mathrm{CI} \\
\text { (mg/L) }\end{array}$ & $\begin{array}{c}\text { IC } \\
F \\
\text { (mg/L) }\end{array}$ & $\begin{array}{c}\mathrm{IC} \\
\mathrm{NO}_{3} \\
\text { (mg/L) }\end{array}$ \\
\hline Mine Pool & 2.35 & $<0.005$ & 33300 & 41000 & 1000 & 2.8 & $<0.5$ & 0.14 & $<0.01$ & 22.8 & 42.5 & $<0.04$ & $<0.08$ \\
\hline MW11 & $<0.1$ & $<0.005$ & 0.37 & 0.48 & 0.02 & 0.7 & $<0.5$ & 0.01 & $<0.01$ & $<3$ & 2.1 & 0.1 & 0.2 \\
\hline Sump 1 & $<0.1$ & $<0.005$ & 3880 & 5600 & 200 & 1.7 & $<0.5$ & 0.07 & $<0.01$ & 37.8 & 40.4 & 0.3 & 0.9 \\
\hline $\begin{array}{l}\text { Stream @ } \\
\text { Sump } 1\end{array}$ & $<0.1$ & $<0.005$ & 506 & 530 & 10 & 1 & $<0.5$ & 0.03 & $<0.01$ & 4.3 & 47.8 & 0.2 & 0.3 \\
\hline Stream Above & $<0.1$ & $<0.005$ & 1.47 & 1.92 & 0.06 & 0.8 & $<0.5$ & 0.02 & $<0.01$ & $<3$ & 50.2 & 0.2 & $<0.08$ \\
\hline Stream Below & $<0.1$ & $<0.005$ & 347 & 460 & 10 & 1.1 & $<0.5$ & 0.03 & $<0.01$ & 3 & 45.7 & 0.2 & $<0.08$ \\
\hline $\begin{array}{c}\text { Equipment } \\
\text { Blank }\end{array}$ & $<0.1$ & $<0.005$ & $<0.1$ & & & $<0.5$ & $<0.5$ & $<0.01$ & $<0.01$ & $<3$ & $<0.06$ & $<0.04$ & $<0.08$ \\
\hline
\end{tabular}



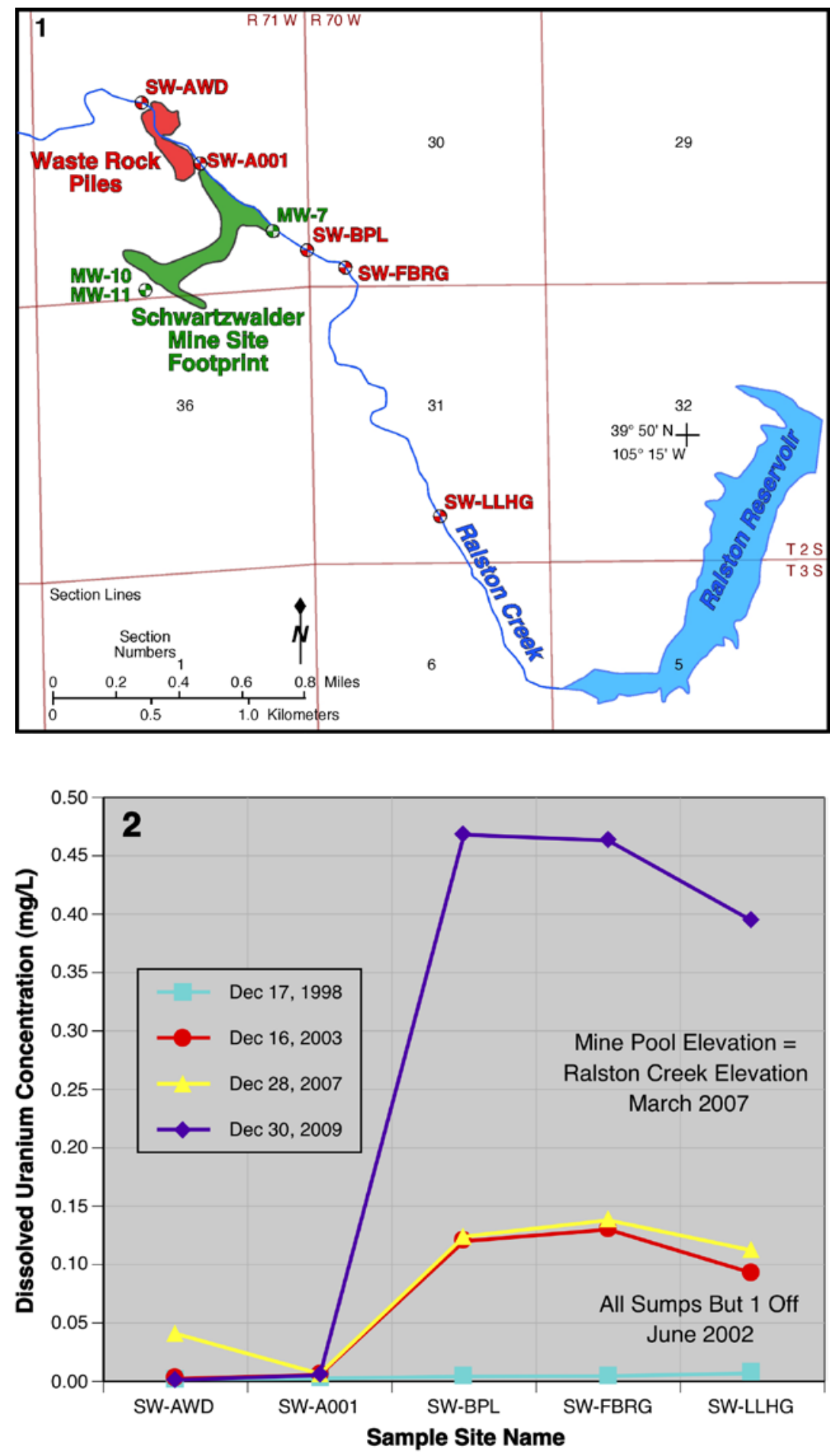

Figure H. (1) Schematic location map of the Schwartzwalder Mine site footprint and surface (SW) and groundwater (MW) sampling sites. (2) Dissolved uranium concentrations along downstream sampling sites on Ralston Creek at specified dates. (3) Dissolved uranium in MW7 and SW-FBRG compared with time. Red lines with black arrows show benchmark dates. MW7 is adjacent to Sump 1 and SW-FBRG is about 2,120 ft downstream from Sump 1. All data and information are from Wyman and Effner, 2007 and Whetstone Associates, 2010. 


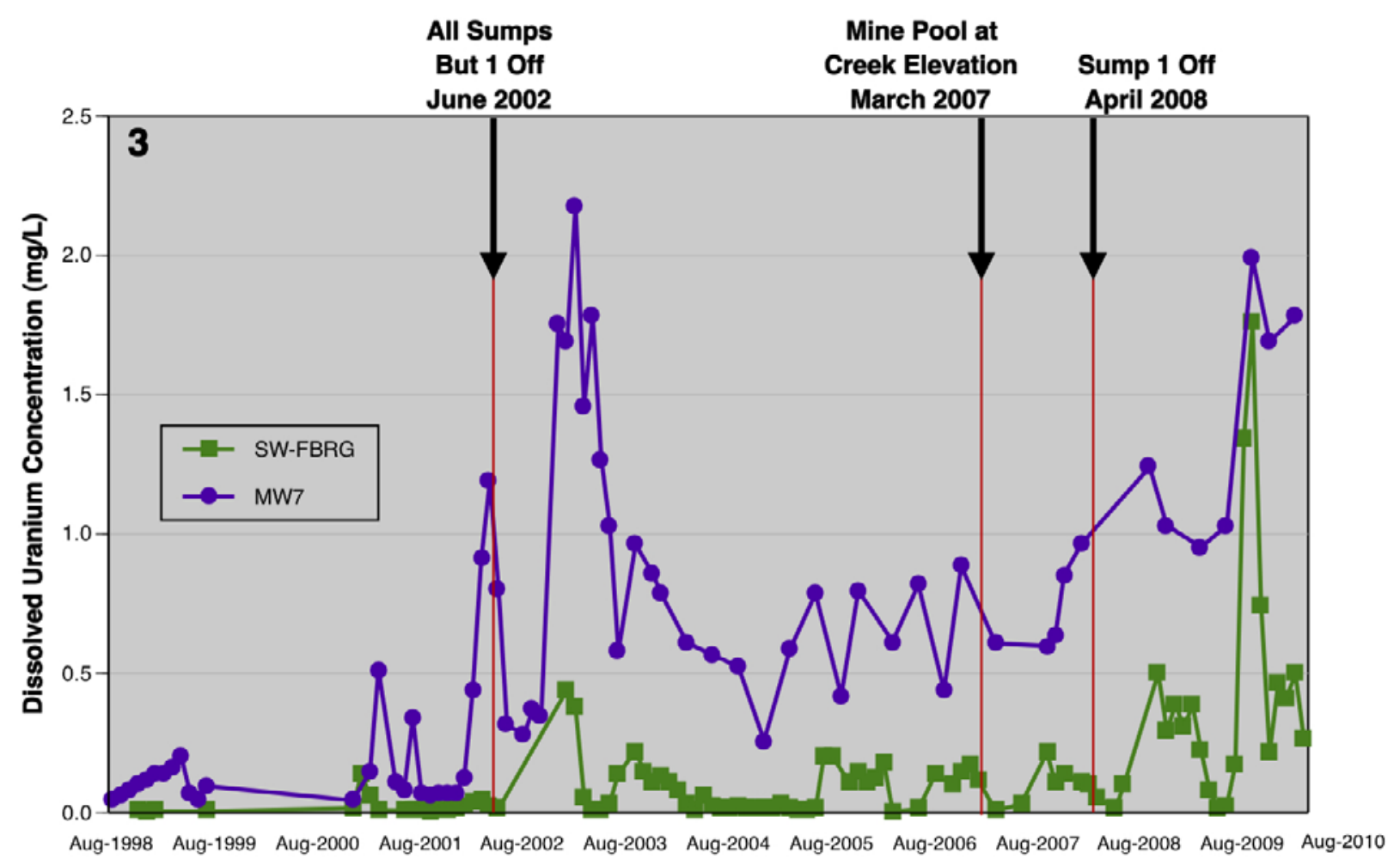

Figure H. (1) Schematic location map of the Schwartzwalder Mine site footprint and surface (SW) and groundwater (MW) sampling sites. (2) Dissolved uranium concentrations along downstream sampling sites on Ralston Creek at specified dates. (3) Dissolved uranium in MW7 and SW-FBRG compared with time. Red lines with black arrows show benchmark dates. MW7 is adjacent to Sump 1 and SW-FBRG is about 2,120 ft downstream from Sump 1. All data and information are from Wyman and Effner, 2007 and Whetstone Associates, 2010.-Continued

and magnitude of uranium concentrations are similar in December 2007 to those in December 2003, but in December 2009, uranium concentrations below the mine site increased dramatically to $0.40-0.45 \mathrm{mg} / \mathrm{L}$ when the mine pool elevation was above the elevation of Ralston Creek and no sump operation or treatment was occurring (Figure H2). This dramatic uranium concentration increase may indicate an approximate two-year travel time for the mine pool water to enter Ralston Creek.

Data reported in Whetstone Associates 2010 further document the increase in uranium concentrations in Ralston Creek from August 1998 to August 2010 (Figure H3). For example, a significant spike in uranium concentration occurred in the fall 2009 at SW-FBRG (Figure H3). Whetstone Associates, 2010 indicates that spring 2009 was particularly wet causing higher than normal water levels in many wells. They interpret the spike in uranium concentrations in Ralston Creek during the fall 2009 to be related to flushing of soluble salts as water levels rose. For sites upgradient from the mine, SW-AWD and
SW-A001, the uranium concentrations are consistently low during the entire study period (Figure $\mathrm{H} 1$ ).

Uranium concentrations in MW-6, MW-7, and MW-9 show an increase shortly after the sumps were turned off in 2002. This is explained in Wyman and Effner, 2007 as a "first flush." From the fall 2003 to the fall 2009, dissolved uranium concentrations in these wells were in the range of about 0.25 to $1 \mathrm{mg} / \mathrm{L}$ (Figure H3 shows data for MW-7). In the fall 2009, dissolved uranium concentrations in MW-6, 7, and 9 all spiked to values of 1.5 to $2.0 \mathrm{mg} / \mathrm{L}$; a spike in uranium concentration in Ralston Creek also mimicked the spike in the wells. This spike and the generally increasing trend in uranium concentrations seen after fall 2009 may indicate increased groundwater flow from the mine pool towards the wells (and Ralston Creek) consistent with the mine pool elevation having risen above the hydraulic heads in MW-6, 7, and 9. Similarly, increased uranium concentrations in Ralston Creek may also indicate increased groundwater flow to the stream from the mine pool through the contaminated alluvium with little to no lag time from the alluvium to the creek. We agree with 
the assessment in Whetstone Associates, 2010 that "results from 2009 may show effect from (1) mine pool water, (2) shut down of the sumps, and (3) from increased precipitation which solubilized uranium from reactive surfaces on the waste rock and fill."

\section{Results and Interpretations for New U.S. Geological Survey Data}

Water sample collection by the U.S. Geological Survey on November 19, 2010 provided comprehensive water quality information for six locations (Figure I) along with new isotopic data (Table C). Mine pool water chemistry was similar to that reported in Wyman and Effner (2007) with dissolved uranium concentration of 33,300 micrograms per liter $(\mu \mathrm{g} / \mathrm{L})(33.3 \mathrm{mg} / \mathrm{L})$ and $1,716 \mathrm{mg} / \mathrm{L}$ sulfate (all sulfate values are reported from ion chromatography analyses in Table C). In contrast, uranium and sulfate concentrations in groundwater collected above the mine site in MW11 were $0.37 \mu \mathrm{g} / \mathrm{L}$ $(0.00037 \mathrm{mg} / \mathrm{L})$ and $14 \mathrm{mg} / \mathrm{L}$, respectively. Concentrations of constituents such as uranium $(3,880 \mu \mathrm{g} / \mathrm{L}=3.88 \mathrm{mg} / \mathrm{L})$ and sulfate $(415 \mathrm{mg} / \mathrm{L})$ in Sump 1 are slightly higher than values reported earlier. Uranium concentrations in samples from Ralston Creek were 0.35 to $0.51 \mathrm{mg} / \mathrm{L}$ below the mine site, similar to 0.3 to $0.6 \mathrm{mg} / \mathrm{L}$ from December 2009 samples reported in Whetstone Associates (2010). Overall, major cation, anion, and trace element data are consistent with previous data collected at the site (Figures J, K, L). Several elemental constituents show relative increases in concentrations from upstream to downstream that include $\mathrm{Ca}, \mathrm{Mg}$, and $\mathrm{Sr}(2 \mathrm{x})$; $\mathrm{Li}, \mathrm{Na}, \mathrm{K}, \mathrm{Rb}$ (2x to 5x); $\mathrm{SO}_{4}$ (7x); $\mathrm{Mo}$ (10x); and U (230x) (Table C). These concentration increases are believed to result from surface- and ground-water rock interactions associated with the Schwartzwalder Mineral deposit.

A plot of specific conductance at locations along Ralston Creek (Figure I2) shows dilute upstream water and increased conductance in water downstream water of the mine site. Downstream increases in alkalinity are not as distinct as for other constituents like uranium.

The $\delta^{13} \mathrm{C}$ value in MW11 (-12.3\%) is consistent with shallow groundwater recharge (Clark and Fritz, 1997). The $\delta^{13} \mathrm{C}$ value in MW11 is affected by atmospheric and soil gas carbon dioxide dissolved into shallow groundwater. All of the other water samples are affected by calcite dissolution, which generates $\delta^{13} \mathrm{C}$ values near zero (Clark and Fritz, 1997). $\delta^{13} \mathrm{C}$ values in the stream range from $-4.8 \%$ above the mine site to $-5.3 \%$ and $-5.6 \%$ below the mine site. The mine pool $\delta^{13} \mathrm{C}$ is $-4.0 \%$ and Sump 1 is $-1.8 \%$, confirming that mine site water is not adding significant alkalinity to the stream as indicated in Figure I5.

Uranium concentrations increase significantly as Ralston Creek passes the mine site (Figure I1). Uranium isotopic ratios $\left({ }^{234} \mathrm{U} /{ }^{238} \mathrm{U}\right)$ are also significantly different in upstream water compared to downstream water (Figure J1). Slow, weatheringrelated leaching of uranium from rocks and soils tends to produce low dissolved uranium concentrations with ${ }^{234} \mathrm{U} /{ }^{238} \mathrm{U}$ ratios greater than unity (in this case more than 1.5). More aggressive leaching of uranium ore bodies under oxidizing conditions, tends to produce uranium-rich groundwater with ${ }^{234} \mathrm{U} /{ }^{238} \mathrm{U}$ ratios closer to unity (Zielinski and others, 1997). The ${ }^{234} \mathrm{U} / 238 \mathrm{U}$ ratios in mine pool and downstream water are similar (1.13-1.14) and this is permissive of a mine pool source for the added uranium. The ${ }^{234} \mathrm{U} / 238 \mathrm{U}$ ratio in Sump 1 is slightly lower (1.12) but similar to the range of values in the mine pool (Figure J1). The use of ${ }^{234} \mathrm{U} /{ }^{238} \mathrm{U}$ activity ratios to identify uranium derived from mine pool water has potential, but additional sampling and additional high precision analyses would be needed (Michael Ketterer, oral commun., 2011).

Sulfate concentrations in Ralston Creek increase significantly downstream from the mine site (Figure I3). Sulfate in upstream water may be derived from naturally occurring sulfur in the volcanogenic metasedimentary Proterozoic bedrock. The $\delta^{34} \mathrm{~S}$ values for MW11 and the stream above the mine site ( $4.1 \%$ and $8.9 \%$, respectively) are within the range of values reported for common water-rock interactions in igneous rocks ( $0 \%$ to $9 \%$, Figure 6.1 in Clark and Fritz, 1997). Bacterially mediated sulfate reduction that precedes the formation of pyrite may produce a significant fractionation of $\delta^{34} \mathrm{~S}$ and sulfate produced from subsequent oxidation of pyrite is typically depleted in $\delta^{34} \mathrm{~S}$ (Clark and Fritz, 1997). An isotopic signature of pyrite oxidation is seen in the mine pool and Sump 1 water with values of $-3.3 \%$ and $-2.7 \%$, respectively.

$\delta^{34} \mathrm{~S}$ values of dissolved sulfate in Ralston Creek change from $8.9 \%$ above the mine site to negative values downstream from the mine site (Figure I4). This dramatic change indicates significant input of groundwater that is rich in sulfate that was produced from pyrite oxidation. Similar to the uranium isotopes, the differences in $\delta^{34} \mathrm{~S}$ values for the mine pool and Sump 1 water are quite small and may represent the range of values to be found in mine pool water. The use of sulfur and uranium isotopes to identify sources works well if isotopically distinct end members are identified (that is, upgradient surface and groundwater compared to mine pool water). Characterization of the isotopic compositional range of each end member will require additional sampling and analyses.

An additional method that could be pursued is the determination of stream loads (flow $\times$ concentration) for various dissolved constituents. In Wyman and Effner (2007), streamflow was not measured accurately enough to determine loads. However, groundwater flow to Ralston Creek can be estimated independently based on changes in stream water chemistry as the stream flows past the mine site. For example, assuming conservative behavior, the changes in dissolved concentrations of $\mathrm{Ca}, \mathrm{K}, \mathrm{Li}, \mathrm{Mg}, \mathrm{Rb}, \mathrm{SO}_{4}, \mathrm{Sr}$, and $\mathrm{Ti}$ in the stream as the water passes the mine site would require a 25 volume percent contribution to the stream from Sump 1 water compared to a 5 percent contribution of the more concentrated mine pool water. While variable mixing of fresh and contaminated groundwater in the alluvium is certainly an added complication, improved streamflow measurements at different times of the year coupled with stream water chemistry could better 

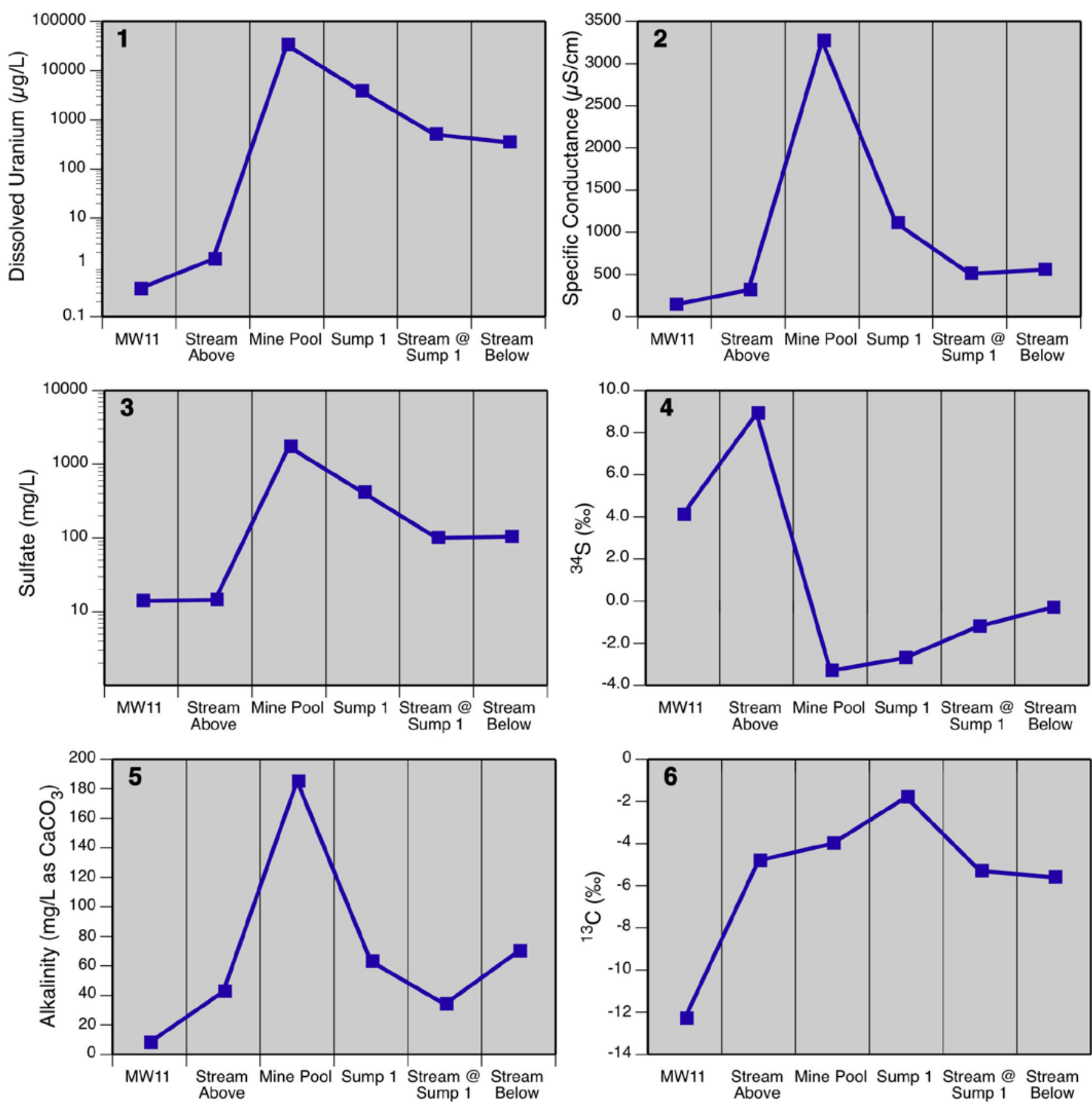

Figure I. Selected geochemical data from six U.S. Geological Survey water samples collected November 19, 2010 plotted against sample location. Data and sample locations in Table C, Figure E. 

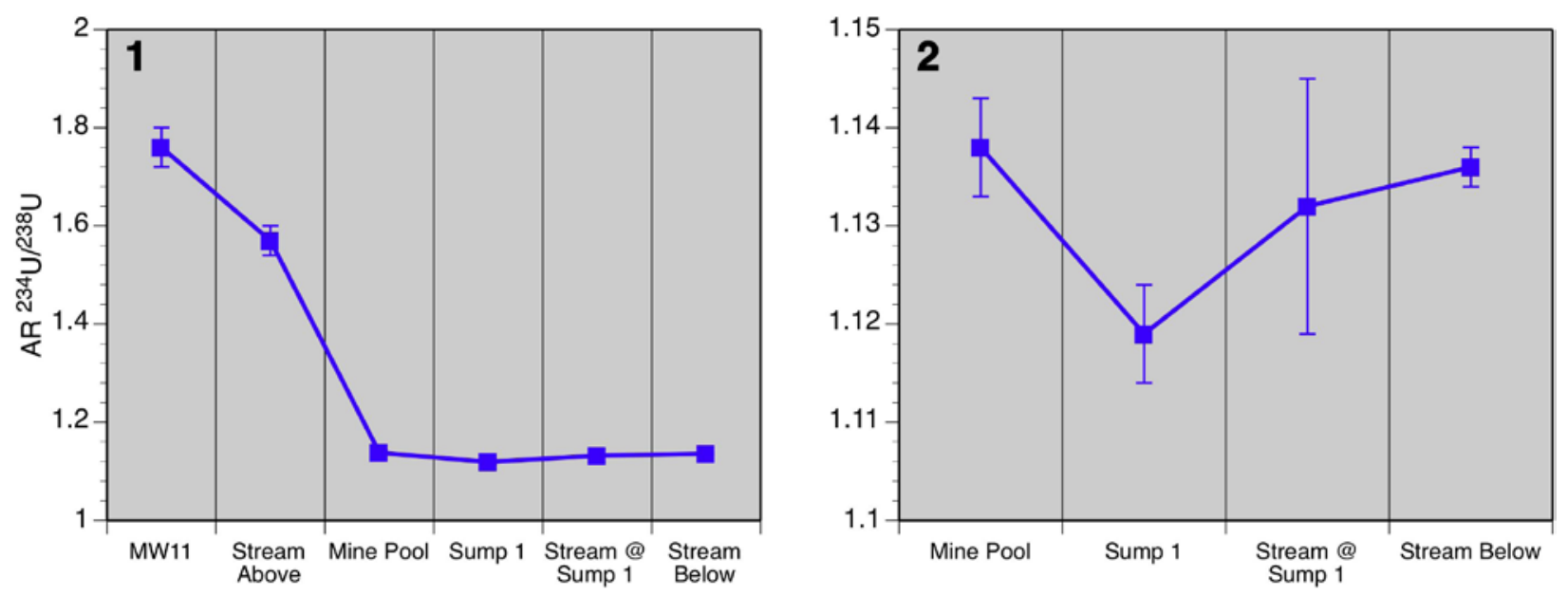

Figure J. Uranium isotopic activity ratios (AR) of ${ }^{234} \mathrm{U}$ and ${ }^{238} \mathrm{U}$ from six U.S. Geological Survey water samples collected on November 19, 2010. (1) All data. (2) Selected data with expanded scale to show analytical error. Data and sample locations in Table C, Figure E.

define this temporal variability of groundwater contributions to Ralston Creek near the mine site.

Chemical data for the six water samples collected by the USGS on November 19, 2010 were analyzed with PHREEQC (Parkhurst and Appelo, 1999) to evaluate saturation indices (minerals that may or may not dissolve or precipitate) of various minerals, including uranium minerals. Our evaluation confirmed the results of a similar assessment by Wyman and Effner (2007). Since our sampling included iron pairs $\left(\mathrm{Fe}^{2+}\right.$, ferrous iron and $\mathrm{Fe}^{3+}$, ferric iron), the assessment of redox conditions is believed to be more accurate (Wyman and Effner, 2007, used redox probes). PHREEQC results from the mine pool sample show that uraninite remains slightly undersaturated $(-1.04$, saturation $=0.0)$ at an Eh of 165 millivolts $(\mathrm{mV})$, based on the iron pair measurements. This value is reasonable considering the high concentrations of dissolved uranium. A sensitivity analysis for variations in Eh show that decreasing Eh to $142 \mathrm{mV}$ causes uraninite to become saturated, which is the equivalent of decreasing the ferric iron concentration from $41 \mu \mathrm{g} / \mathrm{L}$ to $12 \mu \mathrm{g} / \mathrm{L}$. This change to uraninite saturation is within measurement error for the iron pairs ( \pm 5 percent), since ferric iron is only 1 percent of the total iron concentration $(3,930 \mu \mathrm{g} / \mathrm{L})$. These results are similar to those of Wyman and Effner (2007), that slightly more reducing conditions could produce uraninite precipitation and significant drops in dissolved uranium concentrations. To evaluate uraninite precipitation, Wyman and Effner (2007) used an Eh change from $23 \mathrm{mV}$ to $-25 \mathrm{mV}$, at a $\mathrm{pH}$ of 7.53 , which showed a uraninite saturation change from -1.7 (undersaturated) to 0.01 (at saturation).

\section{Critical Questions Regarding the Hydrogeology of the Schwartzwalder Mine and the Source, Transport, and Fate of Dissolved Uranium}

In seeking input from the U.S. Geological Survey on the hydrogeology of the Schwartzwalder Mine site, DRMS sought answers to a number of specific questions. These questions are reproduced below along with answers based on our observations and interpretations of existing data. Answers to the listed questions should be considered preliminary pending further study and the collection of critical new information as discussed in the Conclusions section of this report.

\section{What is the likelihood that groundwater will report from the mine pool to areas beyond the mine?}

It is likely that groundwater from the mine pool will flow to areas beyond the mine in the subsurface; particularly now that the mine pool is above the elevation of Ralston Creek at the location of the Steve Portal and well above the creek along its course further downstream. However, the amounts, flow 

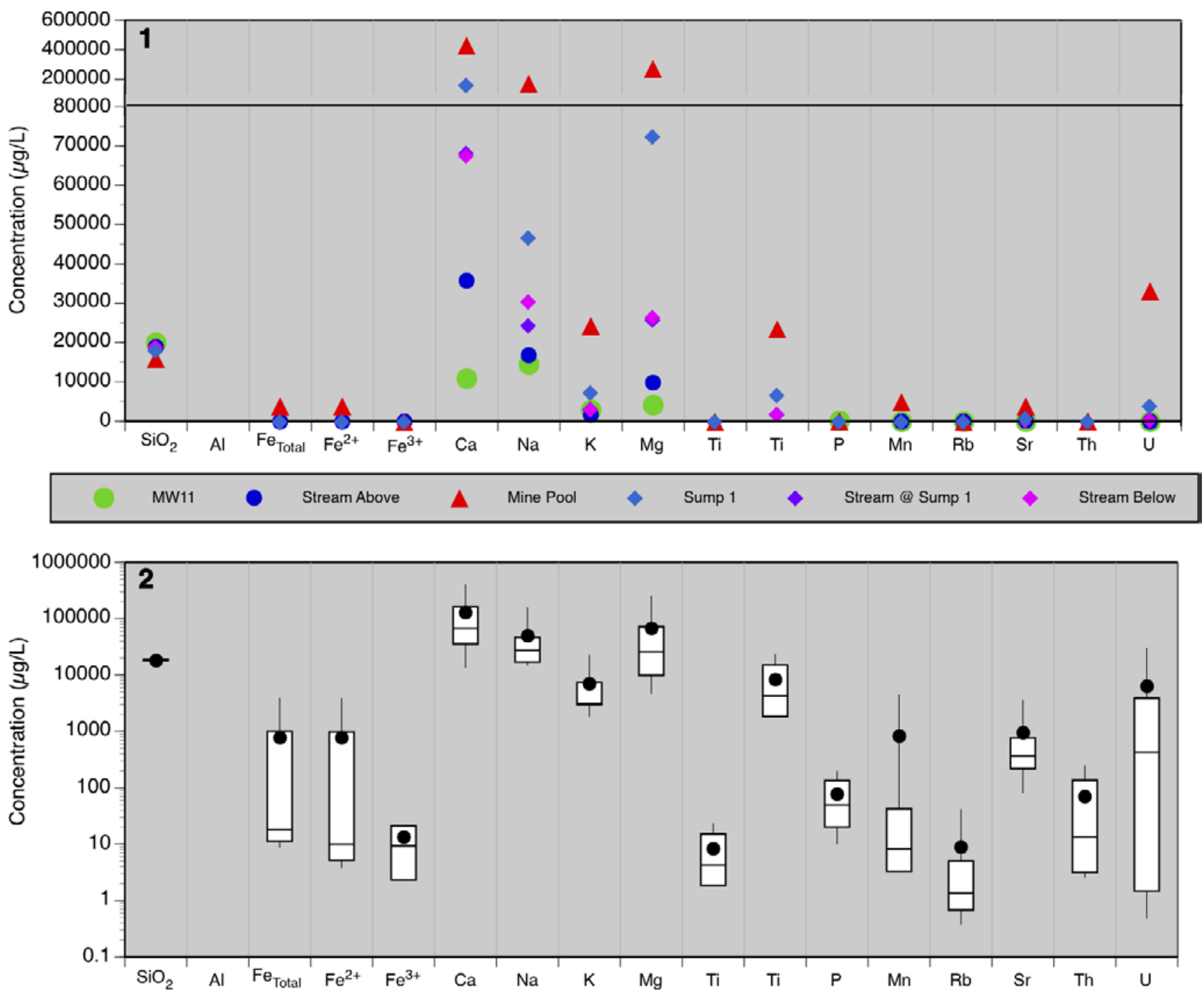

Figure K. Selected geochemical results from six U.S. Geological Survey water samples collected on November 19, 2010 of common major lithophile and radiogenic elements. (1) Site specific concentrations. The scale is linear and expanded from 100,000 $\mu \mathrm{g} / \mathrm{L}$ to $600,000 \mu \mathrm{g} / \mathrm{L}$. (2) Box plot concentrations. For each element shown the bottom and top of each box shows the 25th and 75th percentiles respectively of the data, the horizontal line within each box shows the median, the back dot shows the average, and the endpoints of vertical lines above and below the box shows the 90th and 10th percentiles of the data. 

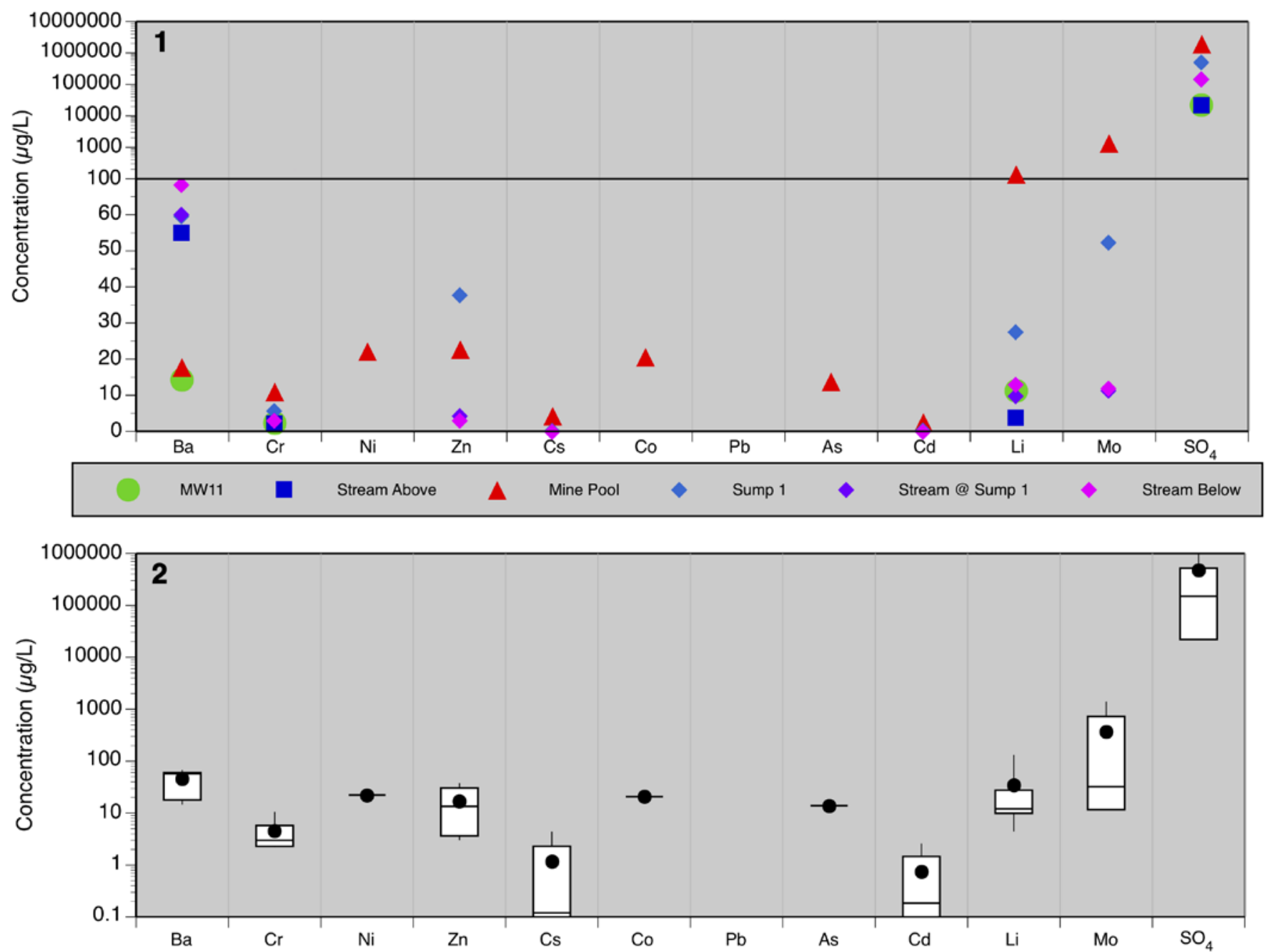

Figure L. Selected geochemical results from six U.S. Geological Survey water samples collected on November 19,2010 of elements commonly found in water associated with epithermal, polymetallic hydrothermal alteration. (1) Site specific concentrations. The scale from 0 to $100 \mu \mathrm{g} / \mathrm{L}$ is linear. Above $100 \mu \mathrm{g} / \mathrm{L}$ the scale is expanded and logarithmic. (2) Box plot concentrations. For each element shown the bottom and top of each box shows the 25th and 75th percentiles respectively of the data, the horizontal line within each box shows the median, the back dot shows the average, and the endpoints of vertical lines above and below the box shows the 90th and 10th percentiles of the data. 
rates, and flow directions of mine water are presently difficult to predict.

\section{What are the likely routes of migration of groundwater from the mine pool?}

Consideration of Darcy's law in conjunction with geological observations and the available data provide some insight. Darcy's law:

$$
\begin{gathered}
Q=K A \frac{\partial h}{\partial l} \text { rearranging, } \\
\frac{Q}{A}=-K \frac{\partial h}{\partial l}=q
\end{gathered}
$$

where $Q=$ volumetric flow rate $\left[\mathrm{L}^{3} / \mathrm{T}\right], K=$ hydraulic conductivity which is negative reflecting the fact that water flows down a hydraulic gradient $[\mathrm{L} / \mathrm{T}], \mathrm{A}=$ cross-sectional area through which flow occurs $\left[\mathrm{L}^{2}\right], \partial h / \partial l=$ the hydraulic head gradient, and $q=$ specific discharge also known as the Darcy velocity $[\mathrm{L} / \mathrm{T}],(\mathrm{L}=$ length and $\mathrm{T}=$ time; for example, Freeze and Cherry 1979). The driving force for groundwater flow is gravity governed by topography and the difference in groundwater elevations from high to low points at the mine site and beyond. From inspection of the topography in the vicinity of the Schwartzwalder Mine groundwater flow may be driven from high to low regions approximately anywhere within the shaded blue region in Figure M. The western most corner and northwestern edge of the blue region are also constrained by the three-dimensional extent of the mine workings in the subsurface.

Wyman and Effner (2007) largely focused on the immediate area of the mine site, which included the area from the vicinity of MW11 down (northeast) to the vicinity of the Steve Portal, the alluvial aquifer, and Ralston Creek. However, inspection of Figure $\mathrm{M}$ shows that based on the inferred head gradients, groundwater flow may also be driven away from the immediate mine site and farther to the east and southeast. This configuration of permissible groundwater flow is partly controlled by the jog in Ralston Creek southeast of the mine site where it passes through the Proterozoic-Paleozoic unconformity (Figures A and B). The depth of active circulation and high $K$ heterogeneities in the bedrock aquifer, both largely unconstrained parameters, also govern the magnitude and directions of flow.

There are three components of the integrated or bulk hydraulic conductivity that may cause heterogeneity at the Schwartzwalder Mine.

1. Variations in the intergranular $K$ of the various rock types. Although the measurements of bulk $K$ provided by Wyman and Effner (2007) do not distinguish between intergranular compared to discrete $K$ (that is, faults and fractures), the $K$ measurements vary over a range $300 \mathrm{x}$ from the minimum to the maximum values.
2. Discrete structures such as faults, veins, and joints that cut across granular matrix form a variety of heterogeneities and such features can cause relatively preferred pathways for groundwater flow. Depending on their orientations, scales of influence, and degree of connectivity they can cause anisotropy in the flow field. Potential exists for such structures, particularly the Illinois fault zone, to be conduits for mine pool water to enter Ralston Creek and many are parallel to the local hydraulic gradient.

3. The mine workings and associated mining related features such as abandoned mineral exploration boreholes. Within the mine workings there is near infinite permeability. The workings terminate to the northeast in the subsurface before reaching the location of Ralston Creek. The location of exploration boreholes is unknown and these could cause additional connectivity for mine pool water to flow outside of the area of the mine workings. The open boreholes could also affect the mine pool elevation if they are connected to the mine pool by way of permeable faults and fractures. See below for further discussion on these boreholes.

\section{What will be the expected rate of groundwater seepage from the mine to offsite locations and when might it be expected to first appear?}

Darcy's law allows the calculation of the Darcy velocity ( $q$, in Equation 3 ) of groundwater flow given estimates of $K$ and the hydraulic head gradient, $\partial h / \partial l$. Darcy velocity is not the actual velocity of groundwater flow moving through a granular media as not all of the pore space within such media is connected. A conservative estimate of the true velocity of groundwater flow is known as the average linear velocity, $v_{\text {avg }}$ $[\mathrm{L} / \mathrm{T}]:$

$$
v_{\text {avg }}=\frac{K}{n_{e}} \frac{\partial h}{\partial l}=\frac{q}{n_{e}}
$$

where $n_{e}=$ effective porosity [dimensionless] that accounts for the connected pore space that conducts groundwater flow moving through a media (Freeze and Cherry, 1979). As previously noted, Wyman and Effner (2007) present hydraulic aquifer test data and estimates of bedrock $K$ s. They also supply what amounts to an estimate of $n_{e}$ about 0.005 , which could reasonably vary between 0.01 and 0.00167 . Using the supplied range of values for $K, n_{e}$, and estimates of $\partial h / \partial l ; v_{\text {avg }}$ was computed along the four representative profiles shown in Figure M. Scenarios that cover the full ranges of $K\left(K_{\text {minimum }}\right.$, $K_{\text {average, }}, K_{\text {median }}$, and $K_{\text {maximum }}$ ) and $n_{e}$ were simulated and travel times, $T_{\text {creek }}$ :

$$
T_{\text {creek }}=\frac{\text { distance traveled }}{v_{\text {avg }}}
$$




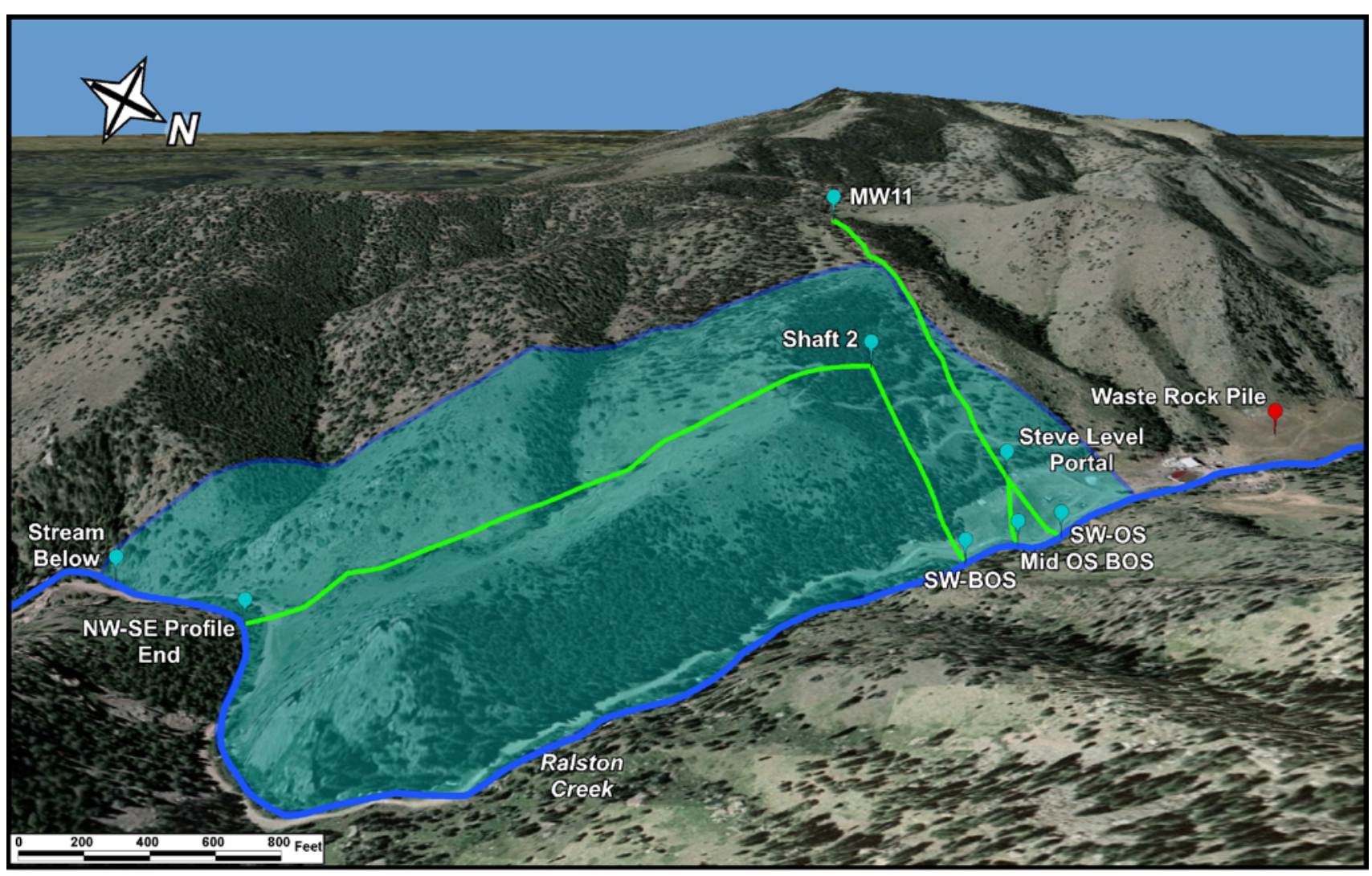

Figure M. Aerial photograph draped on a 3-m resolution digital elevation model and tilted to show topography and the region of permissible groundwater flow down-gradient from the mine workings (blue shaded region). Locations of waterelevation measurement sites are shown as blue drops. Green profile lines indicate where topographic and hydraulic gradients, below the ground surface, are estimated in computations below. View is approximately southwest and looking down from an elevation of approximately 8,500 feet.

were computed for groundwater to reach Ralston Creek in each scenario (Table D).

Representative hydraulic gradients were estimated along each profile shown in Figure M using anchor points of known subsurface groundwater elevations and horizontal distances from the anchors to Ralston Creek. The gradient estimates include: (1) a groundwater table (perhaps similar to the premining condition) about 100 feet below the surface at the top of the hill above the mine at MW11 with northeast flow to Ralston Creek at SW-OS (MW11 Profile); (2) flow northeast from a point where Shaft 2 intersects the mine pool to Ralston Creek at SW-BOS (Shaft 2 Profile); (3) east-northeast flow from a point where the location of the Steve Portal intersects the mine pool to Ralston Creek midway between SW-OS and SW-BOS (Mid OS BOS, Steve Profile); and (4) flow northwest to southeast from a point where Shaft 2 intersects the mine pool to Ralston Creek at the end of the profile line (NWSE Profile).
The estimates of $T_{\text {creek }}$ assume groundwater flow in a homogeneous, isotropic porous media and do not assume that groundwater will arrive at the creek, although it is likely that it will reach the creek. Discrete features such as zones of high intensity fracturing, fault veins, and (or) fault zones are not accounted for in these computations. As noted, Ralston Creek crosses the unconformity between Proterozoic crystalline rocks and Paleozoic sedimentary rocks (Figure B). This contact is a fault zone along some of its surface trace. The probability of high permeability contrasts along the contact may cause anisotropic groundwater flow (see Caine and Forster, 1999 for more discussion of fault-related fluid flow). It is further assumed that Ralston Creek is a discharge area for groundwater flow from regions hydraulically above it. The estimates do not consider the effects of chemical reactions that may retard or enhance concentrations of constituents along the simulated flow paths.

In summary, average linear velocities indicate that the range of estimated travel times is anywhere from about 4 
Table D. Schwartzwalder Mine topographic and hydraulic gradient data and average linear velocity estimates.

[Vertical coordinates are referenced to EGM 96. Unless otherwise noted mine pool and other water elevations from Revised Whetstone Associates Environmental Protection Plan, 8/4/10; *elevations, profiles, and distances determined using Google Earth ${ }^{\circledR}$. Abbreviations: $\mathrm{T}=$ time, $\mathrm{v}=$ velocity, $\mathrm{v}_{\text {avg }}$ =average linear velocity, $\mathrm{L}=$ length, $\mathrm{q}=$ Darcy velocity, $\mathrm{K}=\mathrm{hydraulic}$ conductivity, dh/dl=hydraulic gradient, $\mathrm{n}=$ effective porosity, foot=ft, meter $=\mathrm{m}$, max=maximum, $\min =$ minimum, avg=average, med=median, Creek refers to Ralston Creek; SW-OS, Mid OS BOS, and SW-BOS are sampling sites along Ralston Creek.]

\begin{tabular}{|c|c|c|c|c|c|c|c|c|}
\hline \multicolumn{9}{|c|}{ Topographic and hydraulic gradient data } \\
\hline \multicolumn{2}{|c|}{ Elevation data for hydraulic gradient estimates } & $\begin{array}{l}\text { Elevation } \\
\text { (ft) }\end{array}$ & $\begin{array}{l}\text { Creek at } \\
\text { SW-OS }\end{array}$ & $\begin{array}{l}\text { Creek at } \\
\text { Mid } \\
\text { OS BOS }\end{array}$ & $\begin{array}{l}\text { Creek at } \\
\text { SW-BOS }\end{array}$ & $\begin{array}{l}\text { Creek at } \\
\text { SE Profile } \\
\text { End }\end{array}$ & & \\
\hline \multirow{2}{*}{\multicolumn{2}{|c|}{$\begin{array}{l}\text { Mine pool elevation at Shaft } 2 \text { in Steve Level on 7/1/10 } \\
\text { Assumed pre-mining MW11 water elevation about100 } \\
\text { below surface* }\end{array}$}} & 6,588 & & & & & & \\
\hline & & 7,299 & & & & & & \\
\hline \multicolumn{2}{|c|}{ Mine pool height relative to creek on $7 / 1 / 10$} & & 36 & 40 & 44 & 176 & & \\
\hline Profile name & Location name & $\begin{array}{l}\text { Elevation } \\
\text { (ft) }\end{array}$ & $\begin{array}{c}\text { Topographic } \\
\text { elevation } \\
\text { difference } \\
\text { (ft) }\end{array}$ & $\begin{array}{l}\text { Horizontal } \\
\text { distance } \\
\text { (ft) }\end{array}$ & $\begin{array}{l}\text { Horizontal } \\
\text { distance } \\
\text { (m) }\end{array}$ & $\begin{array}{c}\text { Topographic } \\
\text { gradient }\end{array}$ & $\begin{array}{l}\text { Hydraulic } \\
\text { elevation } \\
\text { difference } \\
\text { (ft) }\end{array}$ & $\begin{array}{c}\text { Hydraulic } \\
\text { gradient }\end{array}$ \\
\hline \multirow[t]{2}{*}{ MW11 Profile (SW to NE) } & MW11 & 7,399 & & & & & & \\
\hline & Creek at SW-OS & 6,552 & 847 & 2,597 & 792 & 0.33 & 747 & 0.288 \\
\hline \multirow[t]{2}{*}{ Shaft 2 Profile (SW to NE) } & Shaft 2 & 6,945 & & & & & & \\
\hline & Creek at SW-BOS & 6,544 & 401 & 991 & 302 & 0.40 & 44 & 0.044 \\
\hline \multirow[t]{2}{*}{ Steve Profile } & Steve Portal & 6,602 & & & & & & \\
\hline & Creek at Mid OS BOS & 6,548 & 54 & 520 & 158 & 0.10 & 40 & 0.077 \\
\hline \multirow[t]{2}{*}{ NW-SE Profile } & Shaft 2 & 6,945 & & & & & & \\
\hline & Creek at SE Profile End* & 6,412 & 533 & 2,598 & 792 & 0.21 & 176 & 0.068 \\
\hline
\end{tabular}

Average linear velocity for bedrock Ks: $\mathrm{q}=\mathrm{Kdh} / \mathrm{dL}$, ne=effective porosity, vavg=q/ne, vavg=(K/ne)dh/dl, Tcreek=travel time to $\mathrm{creek}=\mathrm{L} / \mathrm{vavg}$

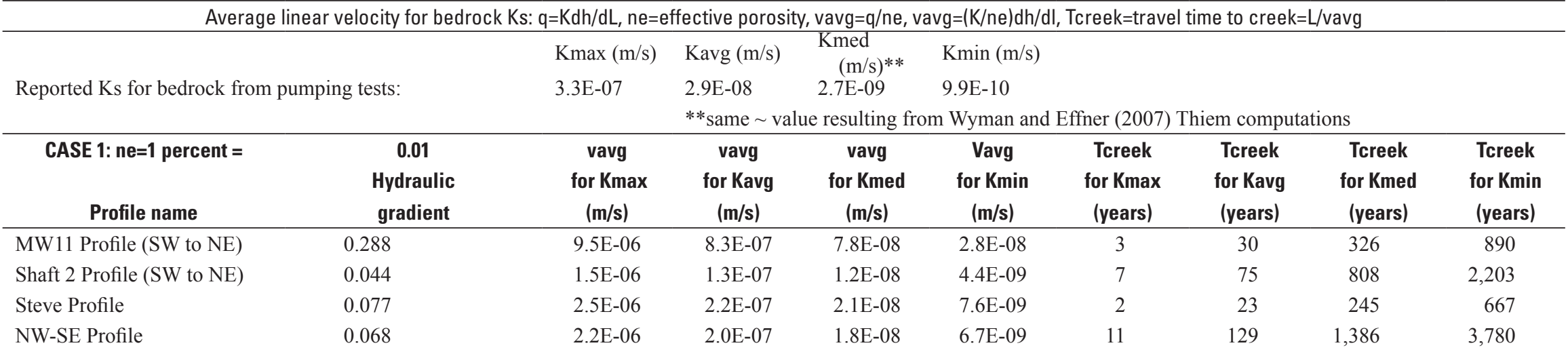


Table D. Schwartzwalder Mine topographic and hydraulic gradient data and average linear velocity estimates. - Continued

[Vertical coordinates are referenced to EGM 96. Unless otherwise noted mine pool and other water elevations from Revised Whetstone Associates Environmental Protection Plan, 8/4/10; *elevations, profiles, and distances determined using Google Earth ${ }^{\circledR}$. Abbreviations: $\mathrm{T}=\mathrm{time}, \mathrm{v}=\mathrm{velocity}, \mathrm{v}_{\text {avg }}=$ average linear velocity, $\mathrm{L}=$ length, $\mathrm{q}=$ Darcy velocity, $\mathrm{K}=\mathrm{hydraulic}$ conductivity, dh/dl=hydraulic gradient, $\mathrm{n}_{\mathrm{e}}=$ effective porosity, foot=ft, meter=m, max=maximum, min=minimum, avg=average, med=median, Creek refers to Ralston Creek; SW-OS, Mid OS BOS, and SW-BOS are sampling sites along Ralston Creek.]

\begin{tabular}{|c|c|c|c|c|c|c|c|c|c|}
\hline $\begin{array}{c}\text { CASE } 2 \text { (reported): ne=0.5 } \\
\text { percent= } \\
\text { Profile name }\end{array}$ & $\begin{array}{c}0.005 \\
\text { Hydraulic } \\
\text { gradient }\end{array}$ & $\begin{array}{c}\text { vavg } \\
\text { for Kmax } \\
(\mathrm{m} / \mathrm{s})\end{array}$ & $\begin{array}{c}\text { vavg } \\
\text { for Kavg } \\
(\mathrm{m} / \mathrm{s})\end{array}$ & $\begin{array}{c}\text { vavg } \\
\text { for Kmed } \\
(\mathrm{m} / \mathrm{s})\end{array}$ & $\begin{array}{c}\text { Vavg } \\
\text { for Kmin } \\
(\mathrm{m} / \mathrm{s})\end{array}$ & $\begin{array}{l}\text { Tcreek } \\
\text { for Kmax } \\
\text { (years) }\end{array}$ & $\begin{array}{l}\text { Tcreek } \\
\text { for Kavg } \\
\text { (years) }\end{array}$ & $\begin{array}{l}\text { Tcreek } \\
\text { for Kmed } \\
\text { (years) }\end{array}$ & $\begin{array}{l}\text { Tcreek } \\
\text { for Kmin } \\
\text { (years) }\end{array}$ \\
\hline MW11 Profile (SW to NE) & 0.288 & $1.9 \mathrm{E}-05$ & $1.7 \mathrm{E}-06$ & $1.6 \mathrm{E}-07$ & $5.7 \mathrm{E}-08$ & 1.3 & 15 & 163 & 445 \\
\hline Shaft 2 Profile (SW to NE) & 0.044 & $2.9 \mathrm{E}-06$ & $2.6 \mathrm{E}-07$ & $2.4 \mathrm{E}-08$ & $8.8 \mathrm{E}-09$ & 3 & 38 & 404 & 1,102 \\
\hline Steve Profile & 0.077 & $5.1 \mathrm{E}-06$ & $4.5 \mathrm{E}-07$ & 4.1E-08 & $1.5 \mathrm{E}-08$ & 1.0 & 11 & 122 & 334 \\
\hline NW-SE Profile & 0.068 & $4.5 \mathrm{E}-06$ & $3.9 \mathrm{E}-07$ & 3.7E-08 & $1.3 \mathrm{E}-08$ & 6 & 65 & 693 & 1,890 \\
\hline $\begin{array}{c}\text { CASE 3: ne }=0.167 \text { percent }= \\
\text { Profile name }\end{array}$ & $\begin{array}{c}0.00167 \\
\text { Hydraulic } \\
\text { gradient }\end{array}$ & $\begin{array}{c}\text { vavg } \\
\text { for Kmax } \\
(\mathrm{m} / \mathrm{s})\end{array}$ & $\begin{array}{c}\text { vavg } \\
\text { for Kavg } \\
(\mathrm{m} / \mathrm{s})\end{array}$ & $\begin{array}{c}\text { vavg } \\
\text { for Kmed } \\
(\mathrm{m} / \mathrm{s})\end{array}$ & $\begin{array}{c}\text { Vavg } \\
\text { for Kmin } \\
(\mathrm{m} / \mathrm{s})\end{array}$ & $\begin{array}{c}\text { Tcreek } \\
\text { for Kmax } \\
\text { (years) }\end{array}$ & $\begin{array}{c}\text { Tcreek } \\
\text { for Kavg } \\
\text { (years) }\end{array}$ & $\begin{array}{c}\text { Tcreek } \\
\text { for Kmed } \\
\text { (years) }\end{array}$ & $\begin{array}{c}\text { Tcreek } \\
\text { for Kmin } \\
\text { (years) }\end{array}$ \\
\hline MW11 Profile (SW to NE) & 0.288 & $5.7 \mathrm{E}-05$ & $5.0 \mathrm{E}-06$ & 4.7E-07 & $1.7 \mathrm{E}-07$ & 0.4 & 5 & 54 & 149 \\
\hline Shaft 2 Profile (SW to NE) & 0.044 & $8.8 \mathrm{E}-06$ & 7.7E-07 & 7.2E-08 & 2.6E-08 & 1.1 & 13 & 135 & 368 \\
\hline Steve Profile & 0.077 & $1.5 \mathrm{E}-05$ & $1.3 \mathrm{E}-06$ & $1.2 \mathrm{E}-07$ & 4.6E-08 & 0.3 & 4 & 41 & 111 \\
\hline NW-SE Profile & 0.068 & $1.3 \mathrm{E}-05$ & $1.2 \mathrm{E}-06$ & $1.1 \mathrm{E}-07$ & $4.0 \mathrm{E}-08$ & 2 & 22 & 231 & 631 \\
\hline
\end{tabular}


months to just under 3,800 years (Table D). For the effective porosity value ( $n_{e}$ about 0.005 ) used by Wyman and Effner (2007) to estimate recharge capture areas and their reported average value of $K\left(2.9 \times 10^{-8} \mathrm{~m} / \mathrm{s}\right)$, the estimated travel times for each hydraulic gradient scenario range from about 11 to 65 years.

\section{Other than the obvious chemical indicators such as uranium concentration, what other chemical or hydrologic indicators could be used to indicate that the mine pool is reporting to Ralston Creek?}

Chemical tracing of inputs of mine pool water to Ralston Creek requires large chemical contrasts in concentration and low dilution of mine water within the creek. Constituents in addition to uranium that show relatively high concentrations in the high total dissolved solids mine pool water include $\mathrm{Ca}$, $\mathrm{Fe}, \mathrm{K}, \mathrm{Li}, \mathrm{Mg}, \mathrm{Mn}, \mathrm{Mo}, \mathrm{Na}, \mathrm{Rb}, \mathrm{SO}_{4}, \mathrm{Sr}$, and Th. Most of these constituents are also elevated in the alluvial groundwater compared to Ralston Creek water, but dissolved Fe, Mn, and Th are not elevated. Under oxidizing conditions that might be found in the alluvial groundwater and as found in Sump 1, $\mathrm{Fe}$ and $\mathrm{Mn}$ react with oxygen to form precipitates of iron and manganese oxides.

A series of low-and-high flow, sumps-on and sumps-off, stream tracer dilution studies (Kimball and others, 2002) could provide chemical loading data and direct measurements of locations and volumes of mine pool and contaminated alluvial groundwater discharge to Ralston Creek. Tracer dilution studies involve pumping a conservative tracer into a stream at a constant rate. During pumping a strategically planned downstream sampling campaign establishes where the tracer concentration is diluted by diffuse or discrete groundwater or tributary inflow. Stream tracer dilution studies cannot detect losses in streamflow, but changes in the tracer concentration allow for calculation of streamflow increases that are far more accurate than manual flow metering. Samples are also analyzed for determination of constituent concentrations from which accurate loading can be determined. Isotopes of uranium and sulfur from samples collected during tracer dilution studies may further provide relatively unique isotopic signatures of mine pool water and its mixing with stream water or alluvial groundwater. In addition, dye tracers and microspheres could be used to indicate pathways and rates of flow over short distances in relatively permeable alluvial sediments.

\section{What are the options for monitoring groundwater migration from the mine pool?}

Continued frequent monitoring of dissolved uranium at previously established locations in Ralston Creek is suggested to document seasonal variability and effects of operations such as recent sump pumping and treatment. In particular, frequent monitoring could allow confident detection of shortterm spikes in dissolved uranium concentrations that might be related to previous transients in mine water inflows.

Direct measurement of groundwater migration from the mine pool would require new monitoring wells that are completed only in the bedrock. If some of these wells were collocated and nested with existing monitoring wells completed only in the alluvial aquifer, they could better document differences in hydraulic head between the bedrock and alluvial aquifers and provide data on the potential direction groundwater may be flowing from one aquifer to another and (or) into Ralston Creek. Additional strategically located bedrock monitoring wells at a variety of depths would provide better three-dimensional understanding of groundwater flow and quality. Time series water level, temperature and geochemical monitoring are suggested in all such wells. Possible locations of other new bedrock monitoring wells include the vicinity of the Minnesota Level and outboard of the mine workings, and in the subdrainage formed in what is referred to as the "Schwartz Trend."

\section{Is it possible that mine pool water could migrate offsite at depth and not report to Ralston Creek?}

One of the poorly understood aspects of the deeper groundwater flow system near the mine workings and downgradient is the depth of active circulation of groundwater. Major geological structures with high, albeit heterogeneous permeability, such as the Illinois fault zone, are present at depth. These complex structures could facilitate transport of shallow groundwater to depths and distances distal from the mine site. Ralston Creek is the low point of hydraulic head for this watershed and relatively deep groundwater flow within the active flow zone may eventually discharge into Ralston Creek at some location downgradient from the mine site. If new bedrock groundwater wells were drilled, several with sufficient depth, they could be used for temperature and geochemical profiling that could establish if there is an effective "base" for flow in the bedrock aquifer.

\section{What approach(s) might be taken in evaluating the "pre-mining baseline" ground water quality in the mineralized, but unmined, bedrock?}

Because of the large changes in the hydraulic heads common in mountain aquifer settings (for example, Manning and Caine, 2007) and the potential for groundwater mixing, little if any, pre-mining groundwater may exist in the active flow system. Establishing pre-mining background groundwater quality is commonly difficult (for example, Nordstrom, 2008). However, dedicated bedrock monitoring wells could be evaluated using tritium-helium isotopic dating methods. If deep bedrock water is untritiated, it could be of pre-mining age and quality. 
Tritium is continually produced in the atmosphere at low concentrations, but was introduced into the atmosphere in large quantities in the 1950 s during nuclear bomb testing. Tritium concentrations in present-day precipitation are approximately 5 tritium units (TU) with variations depending on location. Because of its short half-life (12.3 years), recharged groundwater older than 1950 (or 60 years old) has low levels of tritium (less than $0.5 \mathrm{TU}$ ). Likewise, recharged groundwater that is less than 60 years old does have detectable levels of tritium. More accurate groundwater dating can be achieved knowing the local tritium concentration and concentration of helium as a product of tritium. Tritium measurements indicate an "apparent" age of the groundwater age, as the technique cannot distinguish groundwater mixing.

\section{Potential conduits from the flooded mine workings to the alluvium included historical exploration boreholes that were drilled into the deposit from the valley floor. One of these has been identified but are there methods available to identify the locations of others?}

Electrical geophysical methods, particularly selfpotentials, may help to identify these locations, albeit with important limitations. Self-potentials are sensitive to variable concentrations of electrochemically discernible constituents such as sulfides (for example, Minsley and others, 2010) as well as anthropogenic sources of contamination such as steel (for example, Naudet and others, 2004). The spatial resolution may not be adequate for direct identification of small features such as exploration boreholes, however, the data may indicate where high TDS mine pool water may be emanating reduced bedrock water into the alluvium. Magnetic data may hold promise if there are steel pipes left in the boreholes; however, resolution may be an issue because the survey would have to pass close to the pipes to detect them. Direct current resistivity data could provide auxiliary information about the alluvium thickness and possibly variations in saturation, but data should be focused on several discrete profiles over the area of interest.

\section{Summary}

Given the dual purpose of this report as a technical review of Wyman and Effner (2007) and a presentation of limited new data by the U.S. Geological Survey, summary points are provided in the following two sections.

\section{Review of Wyman and Effner (2007)}

1. Hydrologic data provided in Wyman and Effner (2007) are thorough and comprehensive, but some interpretations of the data are questioned. Methods for estimating infiltration and groundwater recharge are not well documented and integrated into the report. Climatic data from Ralston Reservoir may not be adequate to understand climate at the mine site. Lack of quantification of evapotranspiration hinders estimates of the contribution of infiltration to groundwater recharge and as an effect on the water level of the mine pool.

2. In the formulation of the conceptual groundwater hydrogeological model Wyman and Effner (2007) make some statements that could cause misunderstanding. Statements implying that the bedrock is "impermeable" and does not constitute an aquifer are oversimplifications and are contradicted by data that show hydraulic conductivities in the range of common sandstone aquifers elsewhere. Based on the positive correlation between apparent infiltration from precipitation and inflow to the mine the bedrock aquifer shows behavior consistent with unconfined conditions.

3. Relations between foliations, joints and faults are not well described. The permeability of the primary structure that was mined for uranium, the Illinois fault zone and associated fault vein splays was not described and its geometry relative to Ralston Creek was not addressed in sufficient detail. The suggestion that groundwater flow is primarily vertical in areas away from the mine workings is not supported by data.

4. Uncertainty in the streamflow measurements was not adequately addressed, which effects the proposed locations and magnitudes of discharge into Ralston Creek. More accurate and precise measurements of flow are suggested to accurately identify inflows to the creek from bedrock sources.

5. Although the waste rock piles upgradient from the mine site have been capped and vegetated, their long-term integrity may not have been adequately addressed. The piles could become a contaminant source should their cap rock covers fail in the event of a major flood. Although geochemical sampling has not indicated recent contamination from the waste piles, there is potential for near-surface leachates and runoff from the piles to enter the shallow alluvial aquifer and be discharged downgradient.

6. Use of the Thiem equation for determining an equilibrium water level for the mine pool is inappropriate for several reasons. The most important of these is that drawdowns during the pilot plant-pumping test are superimposed on the unknown, pre-mining static water level. Groundwater rebound to pre-mining conditions remains unknown after the pumping test was started, and no information is created that allows the static water level to be determined. Based on mine pool water levels from 2008, 2009, and 2010 alternate approaches can be used to evaluate if water level rise in the mine workings is complete and how transients may impact the mine pool elevation. 
7. Units for uranium concentrations are not consistently used in the report making it difficult to follow some of the arguments and compare data sets.

8. As noted by Wyman and Effner (2007) it is likely that the "first flush" of dissolved solids after the sumps where shut down in 2002 had an effect on alluvial groundwater and stream water quality. After an apparent lag time for transit, this phenomenon increased the uranium concentrations in Ralston Creek temporarily.

\section{Additional Insights from Observations, New Data, and Data Interpretations of this Report}

1. Structural geological and hydrogeological analysis indicates that the pre-mining, primary segment of the Illinois fault zone that hosted the uranium deposit likely had locally high to extreme permeability. This structure may have contributed metals and sediments to the ancestral Ralston Creek as the creek incised to its current elevation. Although the primary segment of the Illinois fault zone does not cross Ralston Creek at the mine site, several associated fault vein splays do. These faults could act as preferential conduits for mine pool water to enter Ralston Creek. In addition, surface and subsurface data show a pervasive network of open, low angle joints that could facilitate lateral groundwater flow at the mine site and beyond.

2. Dissolved uranium concentrations in the stream above the mine site were low $(1.47 \mu \mathrm{g} / \mathrm{L})$ and high in the mine pool $(33,300 \mu \mathrm{g} / \mathrm{L})$ in November 2010 , both of which are consistent with historical data.

3. Uranium concentrations in November 2010 in MW11, the bedrock monitoring well above and upgradient of the mine site, were also low $(0.37 \mu \mathrm{g} / \mathrm{L})$. Wyman and Effner (2007), reported uranium concentrations in MW11 that are quite variable and had a range of $0.007 \mathrm{mg} / \mathrm{L}$ to 2.63 $\mathrm{mg} / \mathrm{L}(7.0 \mu \mathrm{g} / \mathrm{L}$ to $2,630 \mu \mathrm{g} / \mathrm{L})$. Additional sampling with full well purging may confirm the consistency of these concentrations.

4. Concentrations of total dissolved solids increase as Ralston Creek flows past the mine site. In November 2010, downstream uranium concentrations were $347 \mu \mathrm{g} / \mathrm{L}$ to $506 \mu \mathrm{g} / \mathrm{L}$. These concentration increases were observed even though sumps to collect alluvial groundwater and the water treatment plant were both in operation.

5. Uranium and sulfur isotopes are promising identifiers of mine pool water and mixing in the alluvial aquifer and Ralston Creek. More measurements may better define the isotopic composition of end member mine pool water (high uranium), end member upstream water from Ralston Creek (low uranium), and variations in sump water compared to mine pool water.
6. Projections of the time for the mine pool to attain the elevation of the Steve Level were based on the recent history (July 2010) of changes of mine pool elevation from Wyman and Effner (2007) and suggest a range from about two to seven years or as early as Winter 2012 or as late as Fall 2017. The mine pool water level data show progressive, and sometimes slow, episodic rise of the mine pool elevation indicating that the rate of drainage is currently (2010) slower than the rate of inflow from natural groundwater flow and recharge. Inflow transients during spring are not fully drained over time and cause a net increase in mine pool elevation. It is not clear if the mine pool will continue to rise to reach the Steve Level or higher, or if the recent transients will stabilize. Continued monitoring is suggested.

7. In order to estimate the time for groundwater to flow from the mine pool to Ralston Creek new computations of average linear velocities were completed using several scenarios. The computations are based on data primarily from Wyman and Effner (2007) that allow for estimates of hydraulic head gradients in directions most likely for groundwater flow, likely values of bulk hydraulic conductivities and effective porosities. The results indicate a range of possible groundwater travel times from the mine workings to Ralston Creek of about 4 months to just under 3,800 years. The large range of probable hydraulic conductivities and viable effective porosities causes the large range in computed travel times. When using the reported average hydraulic conductivity and mid-range effective porosity, the travel times are on the order of 11 to 65 years. If a worst-case scenario is considered using the reported maximum hydraulic conductivity and minimum estimate of effective porosity, travel times range from about four months to two years. (It is notable that after the mine pool elevation rose above the elevation of Ralston Creek (about March 2007) the dissolved uranium concentrations in Ralston Creek at the mine site and below more than doubled over about a two-year period.) Estimates of average linear velocity do not account for variable precipitation or dissolution of individual dissolved species through a number of possible chemical reactions.

8. Before March 2007, the mine pool elevation was below the elevation of Ralston Creek, so mine pool groundwater could not flow toward the creek at the mine site. After Sump 1 recirculation was shut down in April 2008, uranium concentrations have been increasing in Ralston Creek during base flow conditions and in the alluvial groundwater as confirmed by new U.S. Geological Survey data collected in November 2010. 


\section{Conclusions}

1. The mine pool elevation continues to rise, albeit at a slow rate, and its elevation is correlated with temporal variations in precipitation. Currently (2010), inflow to the mine workings is greater than outflow through the bedrock aquifer in response to variable recharge events. The equilibrium condition for the mine pool elevation and the magnitude of potential variation from an equilibrium condition, particularly for a consecutive series of wet years, is difficult to predict and unknown at this time.

If the recent record of change of mine pool elevation is representative of future potential changes, the mine pool may reach the Steve Level in approximately two to seven years unless inflow decreases in response to changes in precipitation or outflow increases in response to increased head in the mine pool. The water table elevation of the mine pool is controlled by the three-dimensional head regime; the bulk hydraulic conductivity of the bedrock; the ability of geometrically complex heterogeneities in lithology, structure, and mine workings to enhance or impede outflow; and transients imposed on the system by groundwater recharge.

Numerical groundwater flow modeling could provide some insights; however, there currently are too few data from existing monitoring wells to capture the three-dimensional head regime and how it may vary seasonally. Given that the mine pool is currently (July 2010) about $15 \mathrm{ft}$ below the Steve Level and that the local head gradient is extreme, continued monitoring of the mine pool elevation is suggested for preventing potential seepage of uncontrolled mine pool water into the environment. Drilling of new strategically located monitoring wells, especially ones screened only in bedrock, may provide important head and geochemical data. Geophysical logs for temperature, fluid conductivity, televiewer and flow metering of new wells may better delineate the types, locations, and frequencies of the structures that control flow.

2. Prior to 2007 when the mine pool was below the elevation of Ralston Creek the primary source of uranium to Ralston Creek was contaminated alluvial groundwater. Now that the mine pool elevation is higher than Ralston Creek the concentration of dissolved uranium in alluvial groundwater and Ralston Creek appears to be higher than historic values and is increasing. New pairs of nested wells screened in the bedrock only and in the alluvium only are needed at a variety of appropriate locations to better characterize head between the bedrock and alluvial aquifers, flow directions, and their chemical compositions. Such wells will also provide more detailed monitoring of any contaminated water moving towards Ralston Creek. An additional set of wells located between the Steve Portal and Ralston Creek and near Ralston Creek along "the Schwartz Trend" is also recommended.

3. The Illinois fault zone likely had high local permeability prior to mining. The fault zone is a highly segmented structure with many fault vein splays branching from it. The primary structure that was mined for uranium jogs into parallelism with Ralston Creek but the major segment that hosted the uranium deposit does not appear to cross Ralston Creek at the mine site. However, several minor fault vein splays likely cross Ralston Creek at the mine site based on the observations of such structures at the portal on the northeast side and in line with the mapped trace of the Illinois fault zone. Potential exists for these fault vein splays to act as preferential conduits for mine pool water to eventually enter Ralston Creek. There is a network of surface and subsurface open, albeit likely low permeability, low angle joints that could accommodate lateral groundwater flow. These joint networks are pervasive in the region and are likely the primary control of permeability and permeability anisotropy within the bedrock aquifer away from the fault-related mineral deposits. Mine pool derived water may also travel through the relatively permeable alluvium before reaching the creek. Geochemical reactions along diverse flow paths in bedrock or alluvium may change the chemistry of the water, making identification of a mine pool source more challenging.

4. Stream tracer dilution studies in Ralston Creek would accurately locate and quantify groundwater inflows to the stream and the chemistry of those inflows. Specific sampling during such tracer studies may include locations where the subsidiary structures of the Illinois fault zone cross Ralston Creek to help determine if they are conduits for mine pool water. Ideally, several tracer dilution studies may be considered: One at high flow during runoff, and two at base flow, one with the sumps in operation, and one with them shut down. Construction of flumes or weirs above and below the mine site might also provide longer term monitoring of Ralston Creek discharge and loading if regular samples are collected at such installations. Stream tracer dilution studies could help determine the best locations for such installations. A well drilled through one of the waste rock piles and into the alluvial saturated zone could monitor leaching at the base of the piles and could be tied to monitoring at stream locations near the waste rock piles. A contingency plan for a major flood that could disrupt the piles may be considered.

5. Additional uranium and sulfur isotopic measurements of all sampled water from tracer dilution studies along Ralston Creek, monitoring wells, sumps, and the mine pool have potential for distinguishing groundwater sources. Isotopic compositions of uranium-rich water are insensitive to dilution and thus individual sources such as mine pool water are traceable in the local environment of the mine and downstream from the mine site.

6. The exact locations of each of the now buried adit portals were not provided in Wyman and Effner (2007). Although there are no known mine workings that cross Ralston 
Creek in the subsurface, the completion of accurate mapping of adits and any previously unknown workings are suggested as part of the future reclamation of the mine site because these features are possible sources of outflow of rising mine water that could be sealed.

7. The mine pool water could be sampled to identify any chemical and isotopic heterogeneity with depth or lateral position within the mine workings. This could more accurately and completely characterize this source of uranium and other contaminants.

8. Development of a more complete water budget and hydrologic mass balance for the mine site could better constrain estimates of infiltration rates and amounts of groundwater that lead to seasonal transients in the elevation of the mine pool.

\section{Acknowledgments}

This study was completed in cooperation with the Colorado Division of Reclamation, Mining and Safety. Helpful comments and discussion with Andy Manning, Paul Hsieh, Craig Johnson, and Alan Wallace improved this report. We appreciate the help of John Horton with GIS, image and map production, Ned Sterne and Lyndsay Ball for field assistance and Randy Whicker of Cotter Corporation for access to the mine site and data provided. We thank Edwin P. Weeks and Robert A. Zielinski for critical reviews of this report.

\section{References Cited}

Adams, J.W., Gude, A.J., and Beroni, E.P., 1953, Uranium occurrences in the Golden Gate Canyon and Ralston Creek areas, Jefferson County, Colorado: U.S. Geological Survey Circular 320, p. 16.

Adams, R., and Younger, P.L., 2001, A strategy for modeling ground water rebound in abandoned deep mine systems: Ground Water, v. 39, no. 2, p. 249-261.

Allmendinger, R.W., 2004, Stereonet version 6.3.2 XOrientation data analysis computer code: Absoft Corporation.

Anderson, R.S., Riihimaki, C.A., Safran, E.B., and MacGregor, K.R., 2006, Facing reality—Late Cenozoic evolution of smooth peaks, glacially ornamented valleys, and deep river gorges of Colorado's Front Range, in Willett, S.D., Hovius, N., Brandon, M.T., and Fisher, D.M., eds., Tectonics, climate, and landscape evolution: Geological Society of America Special Paper 398, Penrose Conference Series, p. 397-418.
Bangthanh To, T., Nordstrom, D.K., Cunningham, K.M., Ball, J.W., and McCleskey, R.B., 1999, New method for the direct determination of dissolved $\mathrm{Fe}$ (III) concentration in acid mine waters: Environmental Science and Technology, v. 33, p. $807-813$.

Bossong, C.R., Caine, J.S., Stannard, D.I., Flynn, J.L., Stevens, M.R., and Heiny-Dash, J.S., 2003, Hydrologic conditions and assessment of water resources in the Turkey Creek watershed, Jefferson County, Colorado, 1998-2001: U.S. Geological Survey, Water-Resources Investigations Report 2003-4034, 140 p.

Caine, J.S., Evans, J.P., and Forster, C.B., 1996, Fault zone architecture and permeability structure: Geology, v. 24, p. $1025-1028$.

Caine, J.S., and Forster, C.B., 1999, Fault zone architecture and fluid flow-Insights from field data and numerical modeling, in Haneberg, W.C., Mozley, P.S., Moore, J.C., and Goodwin, L.B., eds., Faults and sub-surface fluid flow in the shallow crust: American Geophysical Union Geophysical Monograph 113, p. 101-127.

Caine, J.S., Manning, A.H., Verplanck, P.L., Bove, D.J., Kahn, K.G., and Ge, S., 2008, U.S. Geological Survey research in Handcart Gulch, Colorado-An alpine watershed affected by metalliferous hydrothermal alteration, in Verplanck, P.L., ed., Understanding contaminants associated with mineral deposits: U.S. Geological Survey Circular 1328, p. 50-57.

Caine, J.S., Ridley, J., and Wessel, Z.R., 2010, To reactivate or not to reactivate- Nature and varied behavior of structural inheritance in the Proterozoic basement of the eastern Colorado Mineral Belt over 1.7 billion years of earth history, in Morgan, L.A., and Quane, S.L., eds., Through the generations - Geologic and anthropogenic field excursions in the Rocky Mountains from modern to ancient: Geological Society of America Field Guide 18, p. 119-140.

Caine, J.S., and Tomusiak, S.R.A., 2003, Brittle structures and their role in controlling porosity and permeability in a complex Precambrian crystalline-rock aquifer system in the Colorado Rocky Mountain Front Range: Geological Society of America Bulletin, v. 115, p. 1410-1424.

Chester, F.M., and Logan, J.M., 1986, Implications for mechanical properties of brittle faults from observations of the Punchbowl fault zone, California: Pure and Applied Geophysics, v. 124, no. 1-2, p. 79-106.

Clark, I.D., and Fritz, P., 1997, Environmental isotopes in hydrogeology: New York, Lewis Publishers, 328 p.

Downs, G.R., and Bird, A.G., 1965, The Schwartzwalder uranium mine, Jefferson County, Colorado: The Mountain Geologist, v. 2, no. 4, p. 183-191. 
Driscoll, F.G., 1986, Groundwater and wells: St. Paul, Minn., Johnson Screens, 1089 p.

DRMS, 2010, Schwartzwalder Mine, Jefferson County, permit no. M-1977-300_Designated mining operation Environmental Protection Plan, technical revision 11-Adequacy review no. 2: Denver, Colorado Division of Reclamation, Mining, and Safety, May 19, 2010.

Freeze, R.A., and Cherry, J.A., 1979, Groundwater: Englewood Cliffs, N.J., Prentice-Hall, 604 p.

Giesemann, A., Jager, H.J., Norman, A.L., Krouse, H.R., and Brand, W.A., 1994, On-line sulfur isotope determination using an elemental analyzer coupled to a mass spectrometer: Analytical Chemistry, v. 66, p. 2816-2819.

Hsieh, P.A., Shapiro, A.M., and Tiedeman, C.R., 1999, Computer simulation of fluid flow in fractured rocks at the Mirror Lake FSE well field, in Morganwalp, D.W., and Buxton, H.T., eds., Subsurface contamination from point sources, v. 3 of U.S. Geological Survey Toxic Substances Hydrology Program-Proceedings of the technical meeting, Charleston, South Carolina, March 8-12, 1999: U.S. Geological Survey Water-Resources Investigations Report 99-4018-C, p. 777-781.

Kamb, W.B., 1959, Ice petrofabric observations from Blue Glacier, Washington, in relation to theory and experiment: Journal of Geophysical Research, v. 64, p. 1891-1909.

Kimball, B.A., Runkel, R.L., Walton-Day, K., and Bencala, K.E., 2002, Assessment of metal loads in watersheds affected by acid mine drainage by using tracer injection and synoptic sampling, Cement Creek, Colorado, USA: Applied Geochemistry, v. 17, no. 9, p. 1183-1207.

Kruseman, G.P., and de Ridder, N.A., 1990, Analysis and evaluation of pumping test data: The Netherlands, International Institute for Land Reclamation and Improvement, Publication 47, 377 p.

Lammering, M., 1973, Impact of the Schwartzwalder mine on the water quality of Ralston Creek, Ralston Reservoir, and upper Long Lake: U.S. Environmental Protection Agency, Region VIII, Technical Investigations Branch, Surveillance and Analysis Division Report SA/TIB-25, 16 p.

Lamothe, P.J., Meier, A.L., and Wilson, S.A., 2002, The determination of forty-four elements in aqueous samples by inductively coupled plasma-mass spectrometry, chap. H of Taggart, J.E., ed., Analytical methods for chemical analysis of geologic and other materials, U.S. Geological Survey: U.S. Geological Survey Open-File Report 02-223-H, 11 p.
Ludwig, K.R., Wallace, A.R., and Simmons, K.R., 1985, The Schwartzwalder uranium deposit-II, Age of uranium mineralization and lead isotope constraints on genesis: Economic Geology, v. 80, no. 7, p. 1858-1871.

Manning, A.H., and Caine, J.S., 2007, Groundwater noble gas, age, and temperature signatures in an Alpine watershed-Valuable tools in conceptual model development: Water Resources Research, v. 43, no. 4, W04404, doi:10.1029/2006WR005349.

Minsley, B.J., Ball, L.B., Burton, B.L., Caine, J.S., CurryElrod, E., and Manning, A.H., 2010, Geophysical characterization of subsurface properties relevant to the hydrology of the Standard Mine in Elk Basin, Colorado: U.S. Geological Survey Open-File Report 2009-1284, 46 p.

Naudet, V., Revil, A., Rizzo, E., Bottero, J.-Y., and Begassat, P., 2004, Groundwater redox conditions and conductivity in a contaminant plume from geoelectrical investigations: Hydrology and Earth System Sciences, v. 8, no. 1, p. 8-22.

Nordstrom, D.K., 2008, Questa baseline and pre-mining ground-water quality investigation. 25. Summary of results and baseline and pre-mining ground-water geochemistry, Red River Valley, Taos County, New Mexico, 2001-2005: U.S. Geological Survey Professional Paper 1728, 111 p.

Norquist, B., 2001, Shrinkage stoping practices at the Schwartzwalder Mine, in Hustrulid, W.A., and Bullock, R.L., eds., Underground mining methods_Engineering fundamentals and international case studies: Society for Mining, Metallurgy, and Exploration, p. 195-204.

Parkhurst, D.L., and Appelo, C.A.J., 1999, User's guide to PHREEQC (version 2) - A computer program for speciation, batch-reaction, one-dimensional transport, and inverse geochemical calculations: U.S. Geological Survey WaterResource Investigations Report 99-4259, 312 p.

Rantz, S.E., 1978, Measurement and computation of streamflow-Measurement of stage and discharge (v. 1); Computation of discharge (v. 2): U.S. Geological Survey Water Supply Paper 2175, 630 p.

Robinson, C.S., 1978, Hydrology of fractured crystalline rocks, Henderson Mine, Colorado: Mining Engineering, v. 30, p. 1185-1194.

Sauer, V.B., and Meyer, R.W., 1992, Determination of error in individual discharge measurements: U.S. Geological Survey Open-File Report 92-144, 21 p. 
Shapiro, A.M., Hsieh, P.A., Mallard, G.E., and Aronson, D.A., 1991, Research in fractured-rock hydrogeology - Characterizing fluid movement and chemical transport in fractured rock at the Mirror Lake drainage basin, New Hampshire: U.S. Geological Survey Open-File Report 91-0088, 7 p.

Sheridan, D.M., Maxwell, C.H., Albee, A.L., and Van Horn, R., 1967, Geology and uranium deposits of the Ralston Buttes District, Jefferson County, Colorado: U. S. Geological Survey Professional Paper 520, 120 p.

Sims, P.K., Sheridan, D.M., King, R.U., Moore, F.B., Richter, D.H., and Schlottman, J.D., 1964, Geology of the uranium deposits in the Front Range, Colorado: U.S. Geological Survey Bulletin 1159, 116 p.

Singh, R.N., and Atkins, A.S., 1984, Application of analytical solutions to simulate mine inflow problems in underground coal mining: International Journal of Mine Water, v. 3, no. 4, p. 1-27.

Soule, J.H., 1960, Mining methods and costs, Schwartzwalder uranium mine, Jefferson County, Colorado: U.S. Bureau of Mines Information Circular 7963, p. 24.

Snow, D.T., 1968, Fracture deformation and change of permeability and storage upon changes of fluid pressure: Colorado School of Mines Quarterly, v. 63, p. 201-244.

Snow, D.T., 1972, Mountain groundwater supplies: The Mountain Geologist, v. 10, no. 1, p. 19-24.

Strunz, H., and Nickel, E.H., 2001, Strunz mineralogical tables-Chemical-structural mineral classification system: Schweizerbart, Stuttgart, 879 p.

Theodorakos, P.M., d'Angelo, W.M., Ficklin, W.H., 2002, Floride, chloride, nitrate, and sulfate in aqueous solutions utilizing AutoSuppression chemically suppressed ion chromatography in Taggart, J.E., ed., Analytical methods for chemical analysis of geologic and other material: U.S. Geological Survey Open-File Report 02-223 [http://pubs. usgs.gov/of/2002/ofr-02-0223/ (last accessed Nov. 15, 2006)].

U.S. Environmental Protection Agency, 40 CFR § 141.66 (e), 2000, Title 40 - Protection of environment, Chapter I Environmental Protection Agency, Subchapter D-Water programs, Part 141 - National primary drinking water regulations, 144.66 - Maximum contaminant levels for radionuclides, (e) MCL for uranium. The maximum contaminant level for uranium is $30 \mu \mathrm{g} / \mathrm{L}$ : Volume 65 , n. 236, Federal Register 76748, December 7, 2000.
U.S. Environmental Protection Agency, 2000, MCL for uranium (40 CFR § 141.66 (e)) [Code of Federal Regulations, Title 40, Section 141.66(e)]: Federal Register, v. 65, no. 236 (December 7, 2000), p. 76748.

Wallace, A.R., and Karlson, R.C., 1985, The Schwartzwalder uranium deposit-I, Geology and structural controls on mineralization: Economic Geology and the Bulletin of the Society of Economic Geologists, v. 80, no. 7, p. 1842-1857.

Wallace, A.R., and Whelan, J.F., 1986, The Schwartzwalder uranium deposit-III, Alteration, vein mineralization, light stable isotopes, and genesis of the deposit: Economic Geology, v. 81, no. 4, p. 872-888.

Whetstone Associates, 2010, Schwartzwalder mine environmental protection plan: Whetstone Associates, Inc., Document no. 4109C.100419, [about 227] p.

Wyman, S., and Effner, S., 2007, Schwartzwalder mine hydrologic evaluations of mine closure and reclamation: Whetstone Associates, Inc., Document no. 4109B.071116, 158 p.

Yang, I.C., and Edwards, K.W., 1984, Releases of radium and uranium into Ralston Creek and Reservoir, Colorado, from uranium mining, in Barney, G.S., Navratil, J.D., and Schulz, W.W., eds., Geochemical behavior of disposed radioactive waste: American Chemical Society Symposium Series, v. 246, p. 271-286.

Younger, P.L., and Robins, N.S., 2002, Challenges in the characterization and prediction of the hydrogeology and geochemistry of mined ground, in Younger, P.L., and Robins, N.S., eds., Mine water hydrogeology and geochemistry: Geological Society of London Special Publication 198, p. 1-16.

Zielinski, R.A., Chafin, D.T., Banta, E.R., and Szabo, B.J., 1997, Use of ${ }^{234} \mathrm{U}$ and ${ }^{238} \mathrm{U}$ isotopes to evaluate contamination of near-surface groundwater with uraniummill effluent-A case study in south-central Colorado, U.S.A.: Environmental Geology, v. 32, no. 2, p. 124-136.

Zielinski, R.A., Otton, J.K., Schumann, R.R., and Wirt, L., 2008, Uranium in surface waters and sediments affected by historical mining in the Denver West 1:100,000 quadrangle, Colorado: U.S. Geological Survey Scientific Investigations Report 2007-5246, 54 p. 
FAULT COMPONENTS

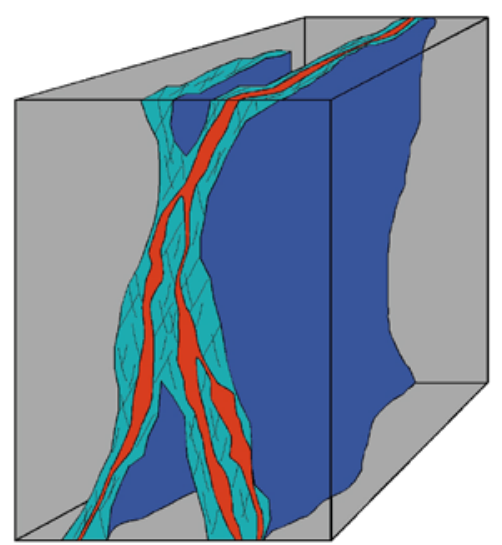

From Caine and others, 1996

FAULT CORE

Gouge

Cataclasite

Breccia

\section{DAMAGE ZONE}

Small faults

Fractures

Veins

Folds

\section{PROTOLITH}

Regional

Structures

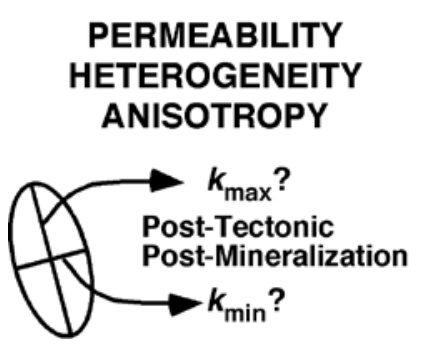

FACTORS CONTROLLING PERMEABILITY $(k)$ AND FLOW

Time of Interest

Lithology

Fault Scale

Fault Type

Deformation Style \&

History

Fluid Chemistry \&

Reactions

Pressure-Temperature

History

Component

Percentage

$k$ Contrast

Anisotropy

Hydraulic Holes

Hydraulic Gradient

Infiltration Magnitude

Surface Water Flow

Direction

Perched Water

Mine Tunnels

\section{FRACTURES}

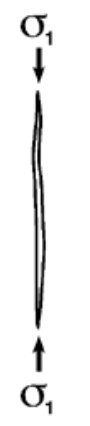

Opening Mode or Joint
FAULT-VEIN COMPONENTS

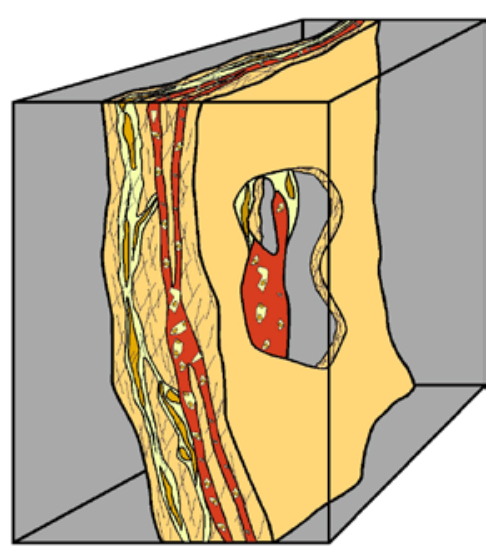

FAULT-VEIN

Discrete Quartz Veins

(Massive \& Stockwork)

Multi-Stage Metals

(Disseminated \& Discrete)

Vugs

Joints

- FAULt CORE

Clay-Rich Gouge

Breccia of Quartz Veins

Cuts Veins

\section{DAMAGE ZONE}

Hydrothermal Alteration

Small faults

Joints

Veins

\section{PROTOLITH}

Regional

Structures

Figure N. Fault zone, fracture, and fault vein conceptual models showing physical components and potential hydrological influences. The ellipse depicts the possible directions of maximum and minimum permeability for a fault or fault vein after they have formed causing them to be complex conduit-barrier systems. A sketch of the basic types of fractures found in nature with the ideal maximum principal stress $\left(\sigma_{1}\right)$ orientation that controls their formation is also shown. 


\section{Appendix: Definitions of Brittle Structures}

Groundwater flow in crystalline rock is commonly controlled by brittle structures. To better understand the characteristics of brittle structures and their potential hydraulic effects, a series of definitions is provided along with a detailed figure depicting these structures (Figure N). The term fracture is nongenetic and simply refers to a crack. Joints are openingmode fractures in which the direction of movement of the two subparallel walls is perpendicular to one another (Figure N). Faults are shearing-mode fractures where the walls slide past one another in directions other than perpendicular to one another. Although a shear fracture can open for an instant, the effect of shearing tends to grind wall-rock materials, which effectively closes the structure. A vein is simply a fracture, whether a joint or fault, that is filled with a mineral precipitate. Veins can also have openings within them referred to as vugs. If a vein has accommodated shear, it is referred to as a fault vein.

Fault zones are complex networks of shear- and openingmode structures, and they commonly contain veins. Fault zones have distinctive components that impart structural, lithological, hydrological, and mechanical heterogeneity into a rock mass (Caine and others, 1996). Components include a fault core where most of the strain has been accommodated and where fault rocks such as gouge or fault breccia form (Figure N). Fault cores are commonly surrounded by and are in sharp contact with a damage zone that is related to the growth of the fault and is composed of networks of small faults, joints, veins, and folds (Chester and Logan, 1986). The contact between a fault core and damage zone is commonly a polished and striated slip surface that can be heterogeneously open or closed. Other damage related to faults include another set of subsidiary structured such as splays, horsetails, and other structures that branch from or are associated with distributed deformation with the rock mass. These fault components are surrounded by the protolith or relatively undeformed host rocks.

Because fault cores are commonly composed of clayrich gouge or crushed and cemented rock, they can have permeability that is orders of magnitude lower than that of the surrounding rocks, thus forming a barrier to groundwater flow. However, some fault zones are composed primarily of networks of open joints with higher permeability than is found in the surrounding rock, causing the fault to be a conduit to flow. Most commonly, fault zones have a core and damage zone that can cause the fault to be both a conduit and a barrier to flow-impeding flow across the fault and enhancing flow parallel to it, depending on the orientation of the hydraulic gradient relative to the orientation of the fault zone (Caine and Forster, 1999). Fault zones can also have internal heterogeneity with multiple cores or poorly developed damage zones (or both). Fault veins can be quite complex with extremely low permeability, massive veins adjacent to clay-rich fault cores, pods of damaged rock, slip surfaces, and fracture networks sandwiched between the veins and gouge. These structures may cause complex baffling and rerouting of groundwater flow that interacts with fault veins (Figure N).

\section{Appendix: Bibliography}

\section{Introduction to Finding and Accessing Bibliographic Information}

The bibliography of materials reviewed for this project is an important aspect of the basic research. Though not all of the materials reviewed were directly referenced in this evaluation, the bibliography provides access to additional scientific research that may be of interest as supplemental material. U.S. Geological Survey library resources were used for comprehensive searches of relevant historical and scientific publications for the Schwartzwalder Uranium Mine, underground mine water rebound, groundwater flow in faulted and fractured crystalline rocks, solute transport of uraniferous groundwater, and other relevant topics. The following summarizes the sources used through the USGS Library to find the citation information, as well as the access points for the public to find and obtain the documents of interest.

Since 1882, the U.S. Geological Survey Library has provided information and data to the Nation. Here in Colorado, the U.S. Geological Survey Library has been available to the public since 1948. Though times have changed with the onset on the Internet, both print and electronic resources are consistently used in every bibliographic request. The public has access to several information sources from the U.S. Geological Survey Library at URL: http://library.usgs.gov. Additionally, the public has access to many geoscience indexes, databases, e-journals, and e-books from computers available for the public to use onsite. Many historical print reference materials, for example publications from the U.S. Bureau of Mines, are also available to the public. Books and journal articles unavailable from the U.S. Geological Survey Library System were obtained by librarians through the network of libraries across the country, and some cases the world, participating in Interlibrary Loan (ILL).

To compile a comprehensive review of the Schwartzwalder Uranium Mine, both print and electronic bibliographic resources were used. Because geology and hydrogeology publications are disseminated and indexed through a variety of sources, commercial databases, library catalogs, agency indexes and bibliographies, and project bibliographies and publication lists were thoroughly reviewed to compile the comprehensive bibliography. The bibliography of materials reviewed are listed by author and organized by using Endnote $^{\mathrm{TM}}$. Duplicate author and title citations exist because papers and reports are published by more than one source and (or) series and it is important to document these references for future research. The primary keyword searches used in various 
appropriate combinations include mine water, mine groundwater rebound, mine pool flooding, fault and fracture, uranium, groundwater, hydrology and hydrogeology, solute transport, vein, Schwartzwalder, Ralston Creek, and Ralston Reservoir. Additionally, the bibliography includes citations of commercial bibliographic online sources used; online open sources available to the public, including several U.S. Geological Survey databases; access points on downloading full-text publications applicable to this assessment; and print indexes utilized to compile bibliographic information on the topic.

Abhilash, S. Singh, Mehta, K.D., Kumar, V., Pandey, B.D., and Pandey, V.M., 2009, Dissolution of uranium from silicate-apatite ore by Acidithiobacillus ferrooxidans: Hydrometallurgy, v. 95, no. 1-2, p. 70-75.

Adamczyk, A., Haladus, A., Szczepanski, A., and Zdechlik, R., 2000, Conceptual dewatering project for closed hardcoal mines of the Sosnowiec sub-system, in Rozkowski, A., ed., Mine water and the environment-Seventh International Mine Water Association Congress, KatowiceUstron, Poland, September 11-15, 2000, Proceedings: Katowice, Poland, Uniwersytet Slaski, p. 206-217.

Adams, J.W., Gude, A.J., and Beroni, E.P., 1953, Uranium occurrences in the Golden Gate Canyon and Ralston Creek areas, Jefferson County, Colorado: U.S. Geological Survey Circular 320, $16 \mathrm{p}$.

Adams, R., and Younger, P.L., 2000, Simulating groundwater rebound in a recently-closed tin mine, in Rozkowski, A., ed., Mine water and the environment-Seventh International Mine Water Association Congress, Katowice-Ustron, Poland, September 11-15, 2000, Proceedings: Katowice, Poland, Uniwersytet Slaski, p. 218-228.

Adams, R., and Younger, P.L., 2001, A strategy for modeling ground water rebound in abandoned deep mine systems: Ground Water, v. 39, no. 2, p. 249-261.

Adams, R., and Younger, P.L., 2002, A physically based model of rebound in South Crofty tin mine, Cornwall, in Younger, P.L., and Robins, N.S., eds., Mine water hydrogeology and geochemistry: Geological Society of London Special Publication 198, p. 89-97.

Adler, H.H., 1963, Concepts of genesis of sandstone-type uranium ore deposits: Economic Geology, v. 58, no. 6, p. $839-852$.

Allmendinger, R.W., 2004, Stereonet version 6.3.2 XOrientation data analysis computer code: Absoft Corporation.
Anderson, R.S., Riihimaki, C.A., Safran, E.B., and MacGregor, K.R., 2006, Facing reality—Late Cenozoic evolution of smooth peaks, glacially ornamented valleys, and deep river gorges of Colorado's Front Range, in Willett, S.D., Hovius, N., and Brandon, M. T. F., D.M., eds., Tectonics, Climate, and Landscape Evolution: Geological Society of America Special Paper 398, Penrose Conference Series, p. 397-418, doi: 10.1130/2006.2398(25).

Anderson, R.S., Riihimaki, C.A., Safran, E.B., and MacGregor, K.R., 2006, Facing reality—Late Cenozoic evolution of smooth peaks, glacially ornamented valleys, and deep river gorges of Colorado's Front Range, in Willett, S.D., Hovius, N., Brandon, M.T., and Fisher, D.M., eds., Tectonics, climate, and landscape evolution: Geological Society of America Special Paper 398, Penrose Conference Series, p. 397-418.

Andrews, J.N., and Kay, R.L.F., 1982, ${ }^{234} \mathrm{U} /{ }^{238} \mathrm{U}$ activity ratios of dissolved uranium in groundwaters from a Jurassic Limestone aquifer in England: Earth and Planetary Science Letters, v. 57, p. 139-151.

Aryafar, A., Ardejani, F.D., and Baafi, E., 2009, Groundwater recovery simulation for determination of post-mining lake formation at the Sangan iron mine, Mashhad, Iran: Journal of Geology and Mining Research, v. 1, no. 5, p. 111-117.

Aryafar, A., Ardejani, F.D., Singh, R., and Shokri, B.J., 2007, Prediction of groundwater inflow and height of the seepage face in a deep open pit mine using numerical finite element model and analytical solutions, in Cidu, R., and Frau, F., eds., Water in mining environments - International Mine Water Association Symposium, Cagliari, Italy, May 27-31, 2007, Proceedings: Cagliari, Italy, Mako Edizioni, p. 313-317.

Aston, T.R.C., and MacLeod-LaFosse, H., 1985, Analysis of water inflows in the Dokin-Morien No. 3 Tunnel, Sydney Coalfield, Nova Scotia: International Journal of Mine Water, v. 4 , no. 3, p. 11-23.

Baker, V.R., 1974, Paleohydraulic interpretation of Quaternary alluvium near Golden, Colorado: Quaternary Research, v. 4, no. 1, p. 94-112.

Bangthanh To, T., Nordstrom, D.K., Cunningham, K.M., Ball, J.W., and McCleskey, R.B., 1999, New method for the direct determination of dissolved $\mathrm{Fe}(\mathrm{III})$ concentration in acid mine waters: Environmental Science and Technology, v. 33 , p. $807-813$. 
Banks, D., Frolik, A., Gzyl, G., and Rogoż, M., 2010, Modeling and monitoring of mine water rebound in an abandoned coal mine complex - Siersza Mine, Upper Silesian Coal Basin, Poland: Hydrogeology Journal, v. 18, p. 519-534.

Banks, D., Parnachev, V.P., Frengstad, B., Holden, W., Vedernikov, A.A., and Karnachuk, O.V., 2002, Alkaline mine drainage from metal sulphide and coal mines-Examples from Svalbard and Siberia, in Younger, P.L., and Robins, N.S., eds., Mine water hydrogeology and geochemistry: Geological Society of London Special Publication 198, p. 287-296.

Bird, A.G., 1958, The petrology and ore deposits of the Schwartzwalder uranium mine, Jefferson County, Colorado: Boulder, Colo., University of Colorado, M.S. thesis, 61 p.

Bird, A.G., 1966, Metamorphic petrology of the Schwartzwalder Mine area, Jefferson County, Colorado: Geological Society of America Special Paper, p. 274.

Bird, A.G., 1979, An epigenetic model for the formation of the Schwartzwalder uranium deposit-A discussion [modified]: Economic Geology and the Bulletin of the Society of Economic Geologists, v. 74, no. 4, p. 947-948.

Bogardi, I., Duckstein, L., Schmieder, A., and Szidarovszky, F., 1980, Stochastic forecasting of mine water inrushes: Advances in Water Resources, v. 3, no. 1, p. 3-8.

Bolger, P., and Brumley, J., 1988, Geological studies for predicting artesian dewatering requirements at Loy Yang open cut, Latrobe Valley, Victoria, Australia, in Third International Mine Water Association Congress, Melbourne, Australia, October 23-28, 1988, Proceedings: Parkville, Australia, p. 699-710.

Bossong, C.R., Caine, J.S., Stannard, D.I., Flynn, J.L., Stevens, M.R., and Heiny-Dash, J.S., 2003, Hydrologic conditions and assessment of water resources in the Turkey Creek watershed, Jefferson County, Colorado, 1998-2001: U.S. Geological Survey, Water-Resouces Investigations Report, 2003-4034, 140 p.

Both, R.A., Arribas, A., and de Saint-Andre, B., 1994, The origin of breccia-hosted uranium deposits in carbonaceous metasediments of the Iberian Peninsula- $\mathrm{U}-\mathrm{Pb}$ geochronology and stable isotope studies of the Fe Deposit, Salamanca Province, Spain: Economic Geology, v. 89, no. 3, p. 584-601.

Boyauda, C., and Therriena, R., 2004, Numerical modeling of mine water rebound in Saizerais, northeastern France, in Miller, C.T., and Pinder, G.F., eds., Computational methods in water resources - Proceedings of the XVth International Conference on Computational Methods in Water Resources [Chapel Hill, N.C., July 13-17, 2004]: Developments in Water Science, v. 55, p. 977-989.
Bretherton, B., 1989, Near-surface acid mine water pools and their implications for mine abandonment, Coeur d'Alene mining district, Idaho: Moscow, Idaho, University of Idaho, M.S. thesis, $152 \mathrm{p}$.

Brouyère, S., Orban, P., Wildemeersch, S., Couturier, J., Gardin, N., and Dassargues, A., 2009, The Hybrid Finite Element Mixing Cell method-A new flexible method for modeling mine water problems: Mine Water and the Environment, v. 28 , no. 2 , p. $102-114$.

Brown, A., 2002, Infiltration to groundwater at high altitude, in Merkel, B.J., Planer-Friedrich, B., and Wolkersdorfer, C., eds., Uranium in the aquatic environment-Proceedings of the International Conference [on] Uranium Mining and Hydrogeology III and the International Mine Water Association Symposium, Freiberg, Germany, 15-21 September 2002: Berlin, Springer-Verlag, p. 925-931.

Brown, A., 2010, Reliable mine water technology: Mine Water and the Environment, v. 29, no. 2, p. 85-91.

Bukowski, P., 2000, Water storage capacity of rock massif in forecasting the flooding process of mine workings, in Rozkowski, A., ed., Mine water and the environment-Seventh International Mine Water Association Congress, KatowiceUstron, Poland, September 11-15, 2000, Proceedings: Katowice, Poland, Uniwersytet Slaski, p. 506-518.

Burke, S.P., Potter, H.A.B., and Jarvis, A., 2005, Groundwater rebound in the South Yorkshire Coalfield-A review of initial modeling: 9th International Mine Water Association Congress, Oviedo, Spain, September 5-7, 2005, Proceedings,p. 223-227.

Caine, J.S., Evans, J.P., and Forster, C.B., 1996, Fault zone architecture and permeability structure: Geology, v. 24, no. 11, p. 1025-1028.

Caine, J.S., and Forster, C.B., 1999, Fault zone architecture and fluid flow-Insights from field data and numerical modeling, in Haneberg, W.C., Mozley, P.S., Moore, J.C. and Goodwin, L.B., eds., Faults and sub-surface fluid flow in the shallow crust: American Geophysical Union Geophysical Monograph 113, p. 101-127.

Caine, J.S., Manning, A.H., Verplanck, P.L., Bove, D.J., Kahn, K.G., and Ge, S., 2008, U.S. Geological Survey research in Handcart Gulch, Colorado-An alpine watershed affected by metalliferous hydrothermal alteration, chap. I of Verplanck, P.L., ed., Understanding contaminants associated with mineral deposits: U. S. Geological Survey Circular 1328 , p. $50-57$. 
Caine, J.S., Ridley, J., and Wessel, Z.R., 2010, To reactivate or not to reactivate-Nature and varied behavior of structural inheritance in the Proterozoic basement of the eastern Colorado Mineral Belt over 1.7 billion years of earth history, in Morgan, L.A., and Quane, S.L., eds., Through the generations-Geologic and anthropogenic field excursions in the Rocky Mountains from modern to ancient: Geological Society of America Field Guide 18, p. 119-140.

Caine, J.S., and Tomusiak, S.R.A., 2003, Brittle structures and their role in controlling porosity and permeability in a complex Precambrian crystalline-rock aquifer system in the Colorado Rocky Mountain Front Range: Geological Society of America Bulletin, v. 115, no. 11, p. 1410-1424.

Canty, G.A., and Everett, J.W., 1998, Using tracers to understand the hydrology of an abandoned underground coal mine, in Throgmorton, D., Nawrot, J., Mead, J., Galetovic, J., and Joseph, W., eds., Fifteenth Annual National Meeting of the American Society for Surface Mining and Reclamation, St. Louis, Mo., May 17-21, 1998, Proceedings: Princeton, American Society for Surface Mining and Reclamation, p. 62-72.

Carpenter, R.H., 1976, Schwartzwalder uranium mine, Jefferson County, Colorado, in Epis, R.C., and Weimer, R.J., eds., Studies in Colorado field geology: Professional Contributions of the Colorado School of Mines, no.8, p. 456-459.

Carter, T.G., Phillips, S.H.E., and Cochrane, P.C., 1992, Integration of chemical cement grouting techniques for controlling mine water inflows through fractured ground, in Borden, R.H., Holtz, R.D., and Juran, I., eds., Grouting, soil improvement and geosynthetics: American Society of Civil Engineers Geotechnical Special Publication 30, p. 410-422.

Cempiel, E., and Pozzi, M., 2000, Hydrogeological conditions and consequences of closing down the "Gliwice" Colliery, in Rozkowski, A., ed., Mine water and the environmentSeventh International Mine Water Association Congress, Katowice-Ustron, Poland, September 11-15, 2000, Proceedings: Katowice, Poland, Uniwersytet Slaski, p. 229-237.

Chalupnik, S., and Wysocka, M., 2000, Removal of radium from mine waters - The experience from the coal mine, in Rozkowski, A., ed., Mine water and the environmentSeventh International Mine Water Association Congress, Katowice-Ustron, Poland, September 11-15, 2000, Proceedings: Katowice, Poland, Uniwersytet Slaski, p. 352-362.

Chester, F.M., and Logan, J.M., 1986, Implications for mechanical properties of brittle faults from observations of the Punchbowl fault zone, California: Pure and Applied Geophysics, v. 124, no. 1-2, p. 79-106.
Christensen, J.N., Conrad, M.E., DePaolo, D.J., and Dresel, P.E., 2007, Isotopic studies of contaminant transport at the Hanford Site, Washington: Vadose Zone Journal, v. 6, no. 4, p. 1018-1030.

Clark, I.D., and Fritz, P., 1997, Environmental isotopes in hydrogeology: New York, Lewis Publishers, 328 p.

Clowes, F., 1889, Deposits of barium sulphate from minewater: Proceedings of the Royal Society of London, v. 46, no. 26-50, p. 368-369.

Cocks, R.J., Ho, G.E., Anda, M., and Dallas, S., 2009, An assessment of Kalgoorlie Consolidated Gold Mines and Boddington Gold Mine water sources and proposed water auditing framework underpinning improved water allocation compliance and reporting: Mining Technology (Transactions of the Institution of Mining and Metallurgy, Section A), v. 118 , no. 3, p. 225-231.

Colorado State Planning Commission, W. C. B., State Engineer, 1939, Water resources of Colorado, Appendix no. 4, Canal diversion data of Colorado: U.S. Geological Survey.

Colorado State Planning Commission, 1939, Canal diversion data of Colorado, appendix 4 of Water resources of Colorado: Denver, Colo., Colorado State Planning Commission, Water Conservation Board, State Engineer, 3 v.

Cripps, J.C., Deaves, A.P., Bell, F.G., and Culshaw, M.G., 1988, Geological controls on the flow of groundwater into underground excavations, in Third International Mine Water Association Congress, Melbourne, Australia, October 23-28, 1988, Proceedings: Parkville, Australia, Australasian Institute of Mining and Metallurgy, p. 77-86.

Day-Lewis, F.D., Lane, J.W., Jr., Hsieh, P.A., and Gorelick, S.M., 2001, Characterization of fractured-rock aquifers using radar, tracer, and hydraulic data, in Fractured Rock 2001 Conference, Toronto, Ontario, March 26-28, 2001.

De Voto, R.H., and Paschis, J.A., 1980, Geology of uranium vein deposits (including Schwartzwalder Mine) in Proterozoic metamorphic rocks, Front Range, Colorado, in Ferguson, J., and Goleby, A.B., eds., Uranium in the Pine Creek geosynclines, Sydney, Australia, June 4-8, 1979, Proceedings: International Atomic Energy Agency Proceedings Series STI/PUB/555, p. 683-692.

Derzay, R.C., and Bird, A.G., 1957, Economic geology of uranium deposits in the Ralston Creek area, Jefferson County, Colorado: U.S. Atomic Energy Commission RME, 42 p.

Diz, H.R., Novak, J.T., and Rimstidt, J., 1999, Iron precipitation kinetics in synthetic acid mine drainage: Mine Water and the Environment v. 18, no. 1, p. 1-14. 
Downs, G.R., and Bird, A.G., 1965, The Schwartzwalder uranium mine, Jefferson County, Colorado: The Mountain Geologist, v. 2, no. 4, p. 183-191.

Driscoll, F.G., 1986, Groundwater and wells: St. Paul, Minn., Johnson Screens, 1089 p.

DRMS, 2010, Schwartzwalder Mine, Jefferson County, Permit No. M-1977-300, Designated Mining Operation Environmental Protection Plan, TR-11, Adequacy Review \#2: Denver, CO, May 19, 2010.

DRMS, 2010, Schwartzwalder Mine, Jefferson County, permit no. M-1977-300 - Designated mining operation Environmental Protection Plan, technical revision 11-Adequacy review no. 2: Denver, Colorado Division of Reclamation, Mining, and Safety, May 19, 2010.

Egal, M., Elbaz-Poulichet, F., Casiot, C., Motelica-Heino, M., Negrel, P., Bruneel, O., Sarmiento, A.M., and Nieto, J.M., 2008, Iron isotopes in acid mine waters and iron-rich solids from the Tinto-Odiel Basin (Iberian Pyrite Belt, Southwest Spain): Chemical Geology, v. 253, no. 3-4, p. 162-171.

Flanigan, V.J., and Young, E.J., 1977, An integrated geologic and geophysical study of the Schwartzwalder uranium mine, Jefferson County, Colorado, Geophysics: Tulsa, Okla., Society of Exploration Geophysicists, p. 1502.

Frankiewicz, A., and Pucek, T.R., 2006, Hydrogeological and hydrochemical characteristics of the partially flooded Piaseczno opencast sulphur mine in southeastern Poland: Mine Water and the Environment, v. 25, no. 3, p. 153-162.

Freeze, R.A., and Cherry, J.A., 1979, Groundwater: Englewood Cliffs, N.J., Prentice-Hall, 604 p.

Gale, J.E., MacLeod, R., and Bursey, G., 1999, The role of hydrogeology in developing effective mine water control programs in fractured porous rocks, in Pickerill, R.K., Barr, S.M., and Williams, G.L., eds., Atlantic geology: Fredericton State, Atlantic Geoscience Society, p. 172.

Gammons, C.H., 2006, Geochemistry of perched water in an abandoned underground mine, Butte, Montana: Mine Water and the Environment, v. 25, no. 2, p. 114-123.

Gammons, C.H., Metesh, J.J., and Snyder, D.M., 2006, A survey of the geochemistry of flooded mine shaft water in Butte, Montana: Mine Water and the Environment, v. 25, no. 2, p. 100-107.

Gammons, C.H., Poulson, S.R., Pellicori, D.A., Reed, P.J., Roesler, A.J., and Petrescu, E.M., 2006, The hydrogen and oxygen isotopic composition of precipitation, evaporated mine water, and river water in Montana, USA: Journal of Hydrology, v. 328, no. 1-2, p. 319-330.
Gandy, C.J., and Younger, P.L., 2007, Predicting groundwater rebound in the South Yorkshire Coalfield, UK: Mine Water and the Environment, v. 26, no. 2, p. 70-78.

Gezahegne, W.A., Planer-Friedrich, B., and Merkel, B.J., 2007, Obtaining stable redox potential reading in gneiss groundwater and mine water-Difficulties, meaningfulness, and potential improvement: Hydrogeology Journal, v. 15, no. 6 , p. $1221-1229$.

Giesemann, A., Jager, H.J., Norman, A.L., Krouse, H.R., and Brand, W.A., 1994, On-line sulfur isotope determination using an elemental analyzer coupled to a mass spectrometer: Analytical Chemistry, v. 66, p. 2816-2819.

Guo, H., Adhikary, D.P., and Craig, M.S., 2009, Simulation of mine water inflow and gas emission during longwall mining: Rock Mechanics and Rock Engineering, v. 42, no. 1, p. 25-51.

Hallenstein, C., and Bastias, J., 1988, Management of Ranger uranium mine waters, Kakadu region, Northern Territory, Australia, in Third International Mine Water Association Congress, Melbourne, Australia, October 23-28, 1988, Proceedings: Parkville, Australia, Australasian Institute of Mining and Metallurgy, p. 753-761.

Hamm, V., Collon-Drouaillet, P., and Fabriol, R., 2008, Two modeling approaches to water-quality simulation in a flooded iron-ore mine (Saizerais, Lorraine, France) - A semi-distributed chemical reactor model and a physically based distributed reactive transport pipe network model: Journal of Contaminant Hydrology, v. 96, no. 1-4, p. 97-112.

Hawkins, J.W., and Dunn, M., 2007, Hydrologic characteristics of a 35-year-old underground mine pool: Mine Water and the Environment, v. 26, no. 3, p. 150-159.

Helm, D.C., 1988, Prediction of groundwater flow in fissured limestone, Blendevale Prospect, Western Australia, in Third International Mine Water Association Congress, Melbourne, Australia, October 23-28, 1988, Proceedings: Parkville, Australia, Australasian Institute of Mining and Metallurgy, p. 299-308.

Hockley, D., Bowell, R., and Day, S., 2000, Mineralogical controls on uranium hydrogeochemistry from mine wastes, in Rozkowski, A., ed., Mine water and the environmentSeventh International Mine Water Association Congress, Katowice-Ustron, Poland, September 11-15, 2000, Proceedings: Katowice, Poland, Uniwersytet Slaski, p. 384-397. 
Holton, D., Kelly, M., and Baker, A., 2002, Paradise lost? Assessment of liabilities at a uranium mine in the Slovak Republic-Novoveska Huta, in Younger, P.L., and Robins, N.S., eds., Mine water hydrogeology and geochemistry: Geological Society of London Special Publication 198, p. 365-377.

Hopkins, W.B., and Simpson, T.A., 1960, Montana earthquakes noted in Pennsylvania mine-water pools: Transactions, American Geophysical Union, v. 41, no. 2, p. 435-436.

Hsieh, P.A., 1998, Scale effects in fluid flow through fractured geologic media, in Sposito, G., ed., Scale dependence and scale invariance in hydrology: Cambridge, United Kingdom, Cambridge University Press, p. 335-353.

Hsieh, P.A., and Shapiro, A.M., 1996, Hydraulic characteristics of fractured bedrock underlying the FSE well field at the Mirror Lake site, Grafton County, New Hampshire, in Morganwalp, D.W., and Aronson, D.A., eds., U.S. Geological Survey Toxic Substances Hydrology ProgramProceedings of the technical meeting, Colorado Springs, Colorado, September 20-24, 1993: U.S. Geological Survey Water-Resources Investigations Report 94-4015, p. $127-130$.

Hsieh, P. A., Shapiro, A. M., and Tiedeman, C. R., 1999, Computer simulation of fluid flow in fractured rocks at the Mirror Lake FSE well field, in Morganwalp, D. W., and Buxton, H. T., eds., U.S.Geological Survey Toxic Substances Hydrology Program--Proceedings of the Technical Meeting, Charleston, South Carolina, March 8-12, 1999--Volume 3 of 3--Subsurface Contamination from Point Sources: U.S. Geological Survey Water-Resources Investigations Report 99-4018C, p. 777-781.

Jackowicz-Korczynski, J., 2000, Assessing of planed inflow and water quality for the closing down mines-Example Niwka-Modrzejow Mine, in Rozkowski, A., ed., Mine water and the environment-Seventh International Mine Water Association Congress, Katowice-Ustron, Poland, September 11-15, 2000, Proceedings: Katowice, Poland, Uniwersytet Slaski, p. 260-270.

Jenk, U., Nindel, K., and Zimmermann, U., 2008, Underground in-situ mine water treatment in a flooded uranium mine at the WISMUT Koenigstein site-Motivation, activities and outlook, in Merkel, B.J., and Hasche-Berger, A., eds., Uranium, mining and hydrogeology: Berlin, Springer, p. 431-436.
Johnson, K., and Younger, P.L., 2000, Abandonment of Frazer's Grove fluorspar mine, North Pennines, UK-Prediction and observation of water level and chemistry changes after closure, in Rozkowski, A., ed., Mine water and the environment-Seventh International Mine Water Association Congress, Katowice-Ustron, Poland, September 11-15, 2000, Proceedings: Katowice, Poland, Uniwersytet Slaski.

Kamb, W.B., 1959, Ice petrofabric observations from Blue Glacier, Washington, in relation to theory and experiment: Journal of Geophysical Research, v. 64, p. 1891-1909.

Kimball, B.A., Runkel, R.L., Walton-Day, K., and Bencala, K.E., 2002, Assessment of metal loads in watersheds affected by acid mine drainage by using tracer injection and synoptic sampling, Cement Creek, Colorado, USA: Applied Geochemistry, v. 17 , no. 9, p. 1183-1207.

Klenowski, G., and Phillips, R.N., 1988, Determination of groundwater inflow rates for longwall mining, German Creek, Bowen Basin, Queensland, in Third International Mine Water Association Congress, Melbourne, Australia, October 23-28, 1988, Proceedings: Parkville, Australia, Australasian Institute of Mining and Metallurgy, p. 21-29.

Klose, C.D., 2007, Mine water discharge and flooding-A cause of severe earthquakes: Mine Water and the Environment, v. 26 , no. 3, p. 172-180.

Koide, K., Yamane, M., and Kobayashi, K., 1998, Heterogeneity of hydraulic conductivity of a fault in sedimentary sequences at the Tono Mine, central Japan, in Fluid flow through faults and fractures in argillaceous formationsProceedings of a joint NEA/EC workshop, Berne, Switzerland, June 10-12, 1996: Paris, France, Organisation for Economic Co-operation and Development, p. 189-198.

Kortas, L., and Younger, P.L., 2007, Using the GRAM model to reconstruct the important factors in historic groundwater rebound in part of the Durham Coalfield, UK: Mine Water and the Environment, v. 26, no. 2, p. 60-69.

Kruseman, G.P., and de Ridder, N.A., 1990, Analysis and evaluation of pumping test data: The Netherlands, International Institute for Land Reclamation and Improvement, Publication 47, 377 p.

Kus, R., and Polozov, Y., 2000, Fighting water hazard by grouting - Practical applications, in Rozkowski, A., ed., Mine water and the environment - Seventh International Mine Water Association Congress, Katowice-Ustron, Poland, September 11-15, 2000, Proceedings: Katowice, Poland, Uniwersytet Slaski, p. 565-576. 
Lachmar, T.E., 1994, Application of fracture-flow hydrogeology to acid-mine drainage at the Bunker Hill Mine, Kellogg, Idaho: Journal of Hydrology, v. 155, no. $1-2$, p. 125-149.

Lammering, M., 1973, Impact of the Schwartzwalder mine on the water quality of Ralston Creek, Ralston Reservoir, and upper Long Lake: U.S. Environmental Protection Agency, Region VIII, Technical Investigations Branch, Surveillance and Analysis Division Report SA/TIB-25, 16 p.

Lamothe, P.J., Meier, A.L., and Wilson, S.A., 2002, The determination of forty-four elements in aqueous samples by inductively coupled plasma-mass spectrometry, chap. $\mathrm{H}$ of Taggart, J.E., ed., Analytical methods for chemical analysis of geologic and other materials: U.S. Geological Survey Open-File Report 02-223-H, 11 p.

Leczfalvy, S., 1982, Simplified mathematical models for the calculation of dewatering, in First International Mine Water Association Congress, Budapest, Hungary, 1982, Proceedings: Budapest, Hungary, Orszagos Magyar Banyaszati es Kohaszati Egyesuelet, p. 28-46.

Ludwig, K.R., Wallace, A.R., and Simmons, K.R., 1985, The Schwartzwalder uranium deposit-II, Age of uranium mineralization and lead isotope constraints on genesis: Economic Geology and the Bulletin of the Society of Economic Geologists, v. 80, no. 7, p. 1858-1871.

Manning, A.H., and Caine, J.S., 2007, Groundwater noble gas, age, and temperature signatures in an Alpine watershedValuable tools in conceptual model development: Water Resources Research, v. 43, no. 4.

Maslyn, R.M., 1978, An epigenetic model for the formation of the Schwartzwalder uranium deposit: Economic Geology and the Bulletin of the Society of Economic Geologists, v. 73 , no. 4 , p. 552-557.

Maslyn, R.M., 1979, An epigenetic model for the formation of the Schwartzwalder uranium deposit - A reply [modified]: Economic Geology and the Bulletin of the Society of Economic Geologists, v. 74, no. 4, p. 948-951.

McCloskey, Lynn, 2005, Mine Waste Technology ProgramUnderground mine source control demonstration project: U.S. Environmental Protection Agency National Risk Management Research Laboratory, EPA/600/R-05/071, 52 p.
McLoughlin, R.P., Grounds, J., and Weatherhead, J., 1988, Nabarlek uranium mine design, construction, operation monitoring and decommissioning of the water management system, in Third International Mine Water Association Congress, Melbourne, Australia, October 23-28, 1988, Proceedings: Parkville, Australia, Australasian Institute of Mining and Metallurgy, p. 775-784.

Michalik, B., Chalupnik, S., and Wysocka, M., 2000, Behaviour of radium discharged with waste waters into the surface settling pond, in Rozkowski, A., ed., Mine water and the environment-Seventh International Mine Water Association Congress, Katowice-Ustron, Poland, September 11-15, 2000, Proceedings: Katowice, Poland, Uniwersytet Slaski, p. 443-455.

Minsley, B.J., Ball, L.B., Burton, B.L., Caine, J.S., CurryElrod, E., and Manning, A.H., 2010, Geophysical characterization of subsurface properties relevant to the hydrology of the Standard Mine in Elk Basin, Colorado: U.S. Geological Survey Open-File Report 2009-1284, 46 p.

Mkandawire, M., Taubert, B., and Dudel, E., 2005, Resource manipulation in uranium and arsenic attenuation by Lemna gibba L. (duckweed) in tailing water of a former uranium mine: Water, Air, \& Soil Pollution, v. 166, no. 1-4, p. $83-101$.

Naudet, V., Revil, A., Rizzo, E., Bottero, J.-Y., and Begassat, P., 2004, Groundwater redox conditions and conductivity in a contaminant plume from geoelectrical investigations: Hydrology and Earth System Sciences, v. 8, no. 1, p. 8-22.

Nelson, C.E., Gallagher, J.R.L., and Schwartzwalder, K., 1982, Proterozoic origins of uranium mineralization in the Colorado Front Range: Economic Geology, v. 77, no. 5, p. 1221-1225.

Nelson, S.T., Karlsson, H.R., Paces, J.B., Tingey, D.G., Ward, S., and Peters, M.T., 2001, Paleohydrologic record of spring deposits in and around Pleistocene pluvial Lake Tecopa, southeastern California: Geological Society of America Bulletin, v. 113, no. 5, p. 659-670.

Nordstrom, D.K., 2008, Questa baseline and pre-mining ground-water quality investigation. 25. Summary of results and baseline and pre-mining ground-water geochemistry, Red River Valley, Taos County, New Mexico, 2001-2005: U.S. Geological Survey Professional Paper 1728, 111 p. 
Norquist, B., 2001, Shrinkage stoping practices at the Schwartzwalder Mine, in Hustrulid, W.A., and Bullock, R.L., eds., Underground mining methods_-Engineering fundamentals and international case studies: Society for Mining, Metallurgy, and Exploration, p. 195-204.

Norton, R., 1988, Mine dewatering, in Third International Mine Water Association Congress, Melbourne, Australia, October 23-28, 1988, Proceedings: Parkville, Australia, Australasian Institute of Mining and Metallurgy, p. 891-900.

Nuttall, C.A., and Younger, P.L., 2004, Hydrochemical stratification in flooded underground mines-An overlooked pitfall: Journal of Contaminant Hydrology, v. 69, no. 1-2, p. 101-114.

O'Hara, G., 2007, Water management aspects of the Britannia Mine Remediation Project, British Columbia, Canada: Mine Water and the Environment, v. 26, no. 1, p. 46-54.

Osiensky, J.L., Williams, R.E., Williams, B., and Johnson, G., 2000, Evaluation of drawdown curves derived from multiple well aquifer tests in heterogeneous environments: Mine Water and the Environment, v. 19, no. 1, p. 30-55.

Parkhurst, D.L., 1988, Mine-water discharge, metal loading, and chemical reactions, in Ragone, S.E., ed., U.S. Geological Survey Program on Toxic Waste-Ground-water contamination. Proceedings of the Second Technical Meeting, Cape Cod, Massachusetts, October 21-25, 1985: U.S. Geological Survey Open-File Report 86-481, p. D5-D9.

Parkhurst, D.L., and Appelo, C.A.J., 1999, User's guide to PHREEQC (version 2) - A computer program for speciation, batch-reaction, one-dimensional transport, and inverse geochemical calculations: U.S. Geological Survey WaterResources Investigations Report 99-4259, 312 p.

Parry, J., 1923, Minerals deposited by bacteria in mine water: Engineering and Mining Journal-Press, v. 115, no. 23, p. 1011-1016.

Paschis, J.A., 1978, Schwartzwalder uranium mine, Ralston Creek canyon, Jefferson County, Colorado, in Shawe, D.R., ed., Guidebook on fossil fuels and metals, eastern Utah and western-southwestern-central Colorado: Professional Contributions of the Colorado School of Mines, no. 9, p. 87-89.

Peng, J., and Shao, A., 1995, Prediction inflow of mine water in Heiwang iron mine by fuzzy logic: Hebei Dizhi Xueyuan Xuebao [Journal of Hebei College of Geology], v. 18, no. 5, p. $442-448$.
Petritz, K.M., Gammons, C.H., and Nordwick, S., 2009, Evaluation of the potential for beneficial use of contaminated water in a flooded mine shaft in Butte, Montana: Mine Water and the Environment, v. 28, no. 4, p. 264-273.

Rantz, S.E., 1978, Measurement and computation of streamflow-Measurement of stage and discharge (v. 1); Computation of discharge (v. 2): U.S. Geological Survey WaterSupply Paper 2175, $630 \mathrm{p}$.

Rapantova, N., Grmela, A., Vojtek, D., Halir, J., and Michalek, B., 2007, Ground water flow modeling applications in mining hydrogeology: Mine Water and the Environment, v. 26, no. 4, p. 264-270.

Rees, S.B., Bowell, R.J., and Wiseman, I., 2002, Influence of mine hydrogeology on mine water discharge chemistry, in Younger, P.L., and Robins, N.S., eds., Mine water hydrogeology and geochemistry: Geological Society of London Special Publication 198, p. 379-390.

Robbins, D.A., 1978, Applied geology in the discovery of the Spokane Mountain uranium deposit, Washington: Economic Geology, v. 73, no. 8, p. 1523-1538.

Robinson, C.S., 1978, Hydrology of fractured crystalline rocks, Henderson Mine, Colorado: Mining Engineering, v. 30 , no. 8 , p. $1185-1194$.

Rogoz, M., and Posylek, E., 2000, Hydrogeological problems connected with closure of mines in the Upper Silesian coal basin, in Rozkowski, A., ed., Mine water and the environment-Seventh International Mine Water Association Congress, Katowice-Ustron, Poland, September 11-15, 2000, Proceedings: Katowice, Poland, Uniwersytet Slaski, p. 319-330.

Rouleau, A., and Gale, J.E., 1987, Stochastic discrete fracture simulation of groundwater flow into an underground excavation in granite: International Journal of Rock Mechanics and Mining Sciences \& Geomechanics Abstracts, v. 24, no. 2, p. 99-112.

Sauer, V.B., and Meyer, R.W., 1992, Determination of error in individual discharge measurements: U.S. Geological Survey Open-File Report 92-144, 21 p.

Schmieder, A., 1978, Forecasting the rates of water inflow into mines, in Water in mining and underground worksFirst World Congress of Water in Mining and Underground Work, SIAMOS, Grenada, Spain, 1978: Madrid, Asociación Nacional de Ingenieros de Minas, p. 510-533. 
Shapiro, A.M., Hsieh, P.A., Mallard, G.E., and Aronson, D.A., 1991, Research in fractured-rock hydrogeology - Characterizing fluid movement and chemical transport in fractured rock at the Mirror Lake drainage basin, New Hampshire: U.S. Geological Survey Open-File Report 91-0088, 7 p.

Sheridan, D.M., Maxwell, C.H., Albee, A.L., and Van Horn, R., 1967, Geology and uranium deposits of the Ralston Buttes District, Jefferson County, Colorado: U.S. Geological Survey Professional Paper 520, 120 p.

Sims, P.K., Sheridan, D.M., King, R.U., Moore, F.B., Richter, D.H., and Schlottman, J.D., 1964, Geology of the uranium deposits in the Front Range, Colorado: U.S. Geological Survey Bulletin 1159, 116 p.

Singh, R.N., and Atkins, A.S., 1984, Application of analytical solutions to simulate mine inflow problems in underground coal mining: International Journal of Mine Water, v. 3, no. 4 , p. 1-27.

Singh, R.N., and Atkins, A.S., 1985a, Analytical techniques for the estimation of mine water inflow: International Journal of Mining Engineering, v. 3, no. 1, p. 65-77.

Singh, R.N., and Atkins, A.S., 1985b, Application of idealised analytical techniques for prediction of mine water inflow: Mining Science \& Technology, v. 2, no. 2, p. 131-138.

Skousen, J., Simmons, J., McDonald, L.M., and Ziemkiewicz, P., 2002, Acid-base accounting to predict post-mining drainage quality on surface mines: Journal of Environmental Quality, v. 31, no. 6, p. 2034-2044.

Snow, D.T., 1968, Fracture deformation and change of permeability and storage upon changes of fluid pressure: Colorado School of Mines Quarterly, v. 63, no. 201-244.

Snow, D.T., 1972, Mountain groundwater supplies: The Mountain Geologist, v. 10, no. 1, p. 19-24.

Soule, J.H., 1960, Mining methods and costs, Schwartzwalder uranium mine, Jefferson County, Colorado: U.S. Bureau of Mines Information Circular 7963, p. 24.

Stahl, R.L., 1974, Detection and delineation of faults by surface resistivity measurements-Schwartzwalder mine, Jefferson County, Colorado: U.S. Bureau of Mines Report of Investigations 7975, $27 \mathrm{p}$.

Strunz, H., and Nickel, E.H., 2001, Strunz mineralogical tables-Chemical-structural mineral classification system: Stuttgart, Schweizerbart, 879 p.
Suksi, J., Rasilainen, K., and Pitkänen, P., 2006, Variations in ${ }^{234} \mathrm{U} /{ }^{238} \mathrm{U}$ activity ratios in groundwater-A key to flow system characterisation?: Physics and Chemistry of the Earth, v. 31 , no. $10-14$, p. $556-571$.

Tate, G., 2003, Putting the legacy of mine water discharge into perspective and the progress in tackling the issues in a fair and consistent manner: Land Contamination \& Reclamation, v. 11, no. 2, p. 281-284.

Theodorakos, P.M., d'Angelo, W.M., and Ficklin, W.H., 2002, Fluoride, chloride, nitrate, and sulfate in aqueous solution utilizing autosuppression chemically suppressed ion chromatography, chap. V of Taggart, J.E., ed., Analytical methods for chemical analysis of geologic and other materials: U.S. Geological Survey Open-File Report 02-223-V.

Thompson, T.B., Sims, P.K., Wallace, S.R., Snow, G.G., Stegen, R.J., Caddy, S.W., Plumlee, G.S., Bryant, Bruce, Beaty, D.W., and Hanshaw, P.M., 1989, Mineral deposits and geology of central Colorado, in Bryant, Bruce, and Beaty, D.W., eds., Mineral deposits of North America, v. 1: American Geophysical Union p. 73.

Tiedeman, C.R., Goode, D.J., and Hsieh, P.A., 1998, Characterizing a ground water basin in a New England mountain and valley terrain: Ground Water, v. 36, no. 4, p. 611-620.

Tonder, G.J.V., Usher, B.H., Dennis, I., and Vermeulen, P.D., 2007, Predicting rebound in a deep colliery in South Africa: Mine Water and the Environment, v. 26, no. 2, p. 79-87.

U.S. Army Corps of Engineers, 1970, Ralston Creek, Leyden Creek, Van Bibber Creek, Lena Gulch, Sanderson Gulch \& North Sanderson Gulch. Flood plain information-Denver metropolitan region, Colorado, v. 5: U.S. Army Corps of Engineers, $68 \mathrm{p}$.

U.S. Environmental Protection Agency, C. e., 2000, Title 40 - Protection of environment, Chapter I - Environmental Protection Agency, Subchapter D - Water programs, Part 141 - National primary drinking water regulations, 144.66 - Maximum contaminant levels for radionuclides, (e) MCL for uranium. The maximum contaminant level for uranium is $30 \mu \mathrm{g} / \mathrm{L}$ : Volume 65, n. 236, Federal Register 76748, December 7, 2000.

U.S. Environmental Protection Agency, 2000, MCL for uranium (40 CFR $\S 141.66$ (e)) [Code of Federal Regulations, Title 40, Section 141.66(e)]: Federal Register, v. 65, no. 236 (December 7, 2000), p. 76748. 
U.S. Geological Survey, 1982, Ore emplacement in the Schwartzwalder mine, Jefferson County, Colorado: U.S. Geological Survey.

Van Tonder, G.J., Usher, B.H., Dennis, I., and Vermeulen, P.D., 2007, Predicting rebound in a deep colliery in South Africa: Mine Water and the Environment v. 26, no. 2, p. $79-87$.

Vincent, S.D., 1989, Application of a ground-water flow model to the hydrogeologic impacts of mine development in unsaturated rock: University of Idaho, M.S. thesis, 41 p.

Wallace, A.R., 1982, Studies of the Schwartzwalder mine, Jefferson County, Colorado: U.S. Geological Survey Professional Paper 1375, 35 p.

Wallace, A.R., 1983a, Alteration and vein mineralization, Schwartzwalder uranium deposit, Front Range, Colorado: Oregon State University, Ph.D. dissertation, 172 p.

Wallace, A.R., 1983b, Alteration and vein mineralization, Schwartzwalder uranium deposit, Front Range, Colorado: U.S. Geological Survey Open-File Report 83-0417, 186 p.

Wallace, A.R., 1983c, Analytical data from host rocks and ores, Schwartzwalder uranium deposit, Front Range, Colorado: U.S. Geological Survey, Open-File Report 83-364, $21 \mathrm{p}$.

Wallace, A.R., and Haefele, W., 1982, Structural and mineralogical characteristics and distribution of carbonatedominated fault breccias associated with uranium deposits, Front Range, Colorado: Economic Geology, v. 77, no. 8, p. $1945-1950$.

Wallace, A.R., and Karlson, R.C., 1985, The Schwartzwalder uranium deposit- $\mathrm{I}$, Geology and structural controls on mineralization: Economic Geology and the Bulletin of the Society of Economic Geologists, v. 80, no. 7, p. 1842-1857.

Wallace, A.R., and Whelan, J.F., 1986, The Schwartzwalder uranium deposit-III, Alteration, vein mineralization, light stable isotopes, and genesis of the deposit: Economic Geology and the Bulletin of the Society of Economic Geologists, v. 81 , no. 4 , p. $872-888$.

Water Resources Scientific Information Center, 1975, Acid mine water-A bibliography: Water Resources Scientific Information Center, Bibliography series 75-202, 564 p.

Whetstone Associates, 2010, Schwartzwalder mine environmental protection plan: Whetstone Associates, Inc., Document no. 4109C.100419, [about 227] p.
Wildemeersch, S., Brouyere, S., Orban, P., Couturier, J., Dingelstadt, C., Veschkens, M., and Dassargues, A., 2010, Application of the Hybrid Finite Element Mixing Cell method to an abandoned coalfield in Belgium: Journal of Hydrology v. 392, no. 3-4, p. 188-200.

Wilson, C.R., Witherspoon, P.A., Long, J.C.S., Galbraith, R.M., DuBois, A.O., and McPherson, M.J., 1983, Largescale hydraulic conductivity measurements in fractured granite: International Journal of Rock Mechanics and Mining Sciences \& Geomechanics Abstracts, v. 20, no. 6, p. 269-276.

Winters, W.R., and Capo, R.C., 2004, Ground water flow parameterization of an Appalachian coal mine complex: Ground Water, v. 42, no. 5, p. 700-710.

Wojtkowiak, F., Couillet, J.-C., Daupley, X., and Tauziede, C., 2000, Geotechnical and environmental impacts on the surface of the water rising in French underground coal mines after closure, in Rozkowski, A., ed., Mine water and the environment-Seventh International Mine Water Association Congress, Katowice-Ustron, Poland, September 11-15, 2000, Proceedings: Katowice, Poland, Uniwersytet Slaski, p. 180-194.

Wolkersdorfer, C., 2002, Mine water tracing, in Younger, P.L., and Robins, N.S., eds., Mine water hydrogeology and geochemistry: Geological Society of London Special Publication 198, p. 47-60.

Wolkersdorfer, C., and Thiem, G., 1999, Ground water withdrawal and land subsidence in northeastern Saxony (Germany): Mine Water and the Environment, v. 18, no. 1, p. 81-92.

Wright, J.H., Wallace, A.R., and Karlson, R.C., 1985, New studies at the Schwartzwalder Mine, Jefferson County, Colorado, in Sibbald, T.I.I., and Petruk, W., eds., Geology of uranium deposits-Proceedings of the CIM-SEG uranium symposium, September 1981: Canadian Institute of Mining and Metallurgy Special Volume 32, p. 262.

Wright-McLaughlin Engineers and Urban Drainage and Flood Control District (Colo.), 1977, Ralston Creek and Leyden Creek, major drainageway planning - Phase B, master plan: Denver, Colo., Wright-McLaughlin Engineers [variously paged].

Wu, Q., and Zhou, W., 2008, Prediction of groundwater inrush into coal mines from aquifers underlying the coal seams in China-Vulnerability index method and its construction: Environmental Geology, v. 56, no. 2, p. 245-254. 
Wu, Q., Zhou, W., Wang, J., and Xie, S., 2009, Prediction of groundwater inrush into coal mines from aquifers underlying the coal seams in China-Application of vulnerability index method to Zhangcun coal mine, China: Environmental Geology, v. 57, no. 5, p. 1187-1195.

Wyman, S., and Effner, S., 2007, Schwartzwalder mine hydrologic evaluations of mine closure and reclamation: Whetstone Associates, Inc., Document no. 4109B.071116, $158 \mathrm{p}$.

Yang, I.C., and Edwards, K.W., 1984, Releases of radium and uranium into Ralston Creek and Reservoir, Colorado, from uranium mining, in Barney, G.S., Navratil, J.D., and Schulz, W.W., eds., Geochemical behavior of disposed radioactive waste: American Chemical Society Symposium Series 246, p. 271-286.

Young, E.J., 1977, Geologic, radiometric, and mineralogic maps and underground workings of the Schwartzwalder uranium mine and area, Jefferson County, Colorado: U.S. Geological Survey Open-File Report 77-725, 41 p.

Young, E.J., 1979, Analytical data on the Schwartzwalder uranium deposit, Jefferson County, Colorado: U.S. Geological Survey Open-File Report 79-968, 36 p.

Young, E.J., 1985, Summary of the geology, economic aspects, and geochemistry of the Schwartzwalder uraniumbearing area, Ralston Buttes district, Jefferson County, Colorado: U.S. Geological Survey Bulletin 1555, 32 p.

Young, E.J., and Paschis, J.A., 1979, Genesis of the Schwartzwalder uranium deposit, Jefferson County, Colorado: Rocky Mountain Geology, v. 17, no. 2, p. 179-186.

Younger, P.L., 2002, Deep mine hydrogeology after closureInsights from the UK, in Merkel, B.J., Planer-Friedrich, B., and Wolkersdorfer, C., eds., Uranium in the aquatic environment-Proceedings of the International Conference [on] Uranium Mining and Hydrogeology III and the International Mine Water Association Symposium, Freiberg, Germany, 15-21 September 2002: Berlin, Springer-Verlag, p. 25-40.

Younger, P.L., 2008, Towards regulatory criteria for discharging iron-rich mine water into the Sea: Mine Water and the Environment, v. 27, no. 1, p. 56-61.

Younger, P.L., and Robins, N.S., 2002, Challenges in the characterization and prediction of the hydrogeology and geochemistry of mined ground, in Younger, P.L., and Robins, N.S., eds., Mine water hydrogeology and geochemistry: Geological Society of London Special Publication 198, p. $1-16$.
Younger, P.L., and Wolkersdorfer, C., 2004, Mine water monitoring: Mine Water and the Environment, v. 23, supplement 1, p. S45-S52.

Younger, P.L., Yardley, B.W.D., Taylor, G., Whitham, A., Smith, M., Griffiths, J., Rivett, M., Arthur, J., Kendall, M., Leat, P., Thomas, L., Peacock, S., Catt, J., and Robinson, R., 2007, Mine water-Friend or foe?, in Earth sciences in the service of society-Bicentennial conference, London, September 10-12, 2007 [abstracts]: Geological Society of London, p. 45.

Zhang, L., and Franklin, J.A., 1993, Prediction of water flow into rock tunnels-An analytical solution assuming an hydraulic conductivity gradient: International Journal of Rock Mechanics and Mining Sciences \& Geomechanics Abstracts, v. 30, no. 1, p. 37-46.

Zielinski, R.A., Chafin, D.T., Banta, E.R., and Szabo, B.J., 1997, Use of ${ }^{234} U$ and ${ }^{238} U$ isotopes to evaluate contamination of near-surface groundwater with uranium-mill effluent-A case study in south-central Colorado, U.S.A.: Environmental Geology, v. 32, no. 2, p. 124-136.

Zielinski, R.A., Otton, J.K., Schumann, R.R., and Wirt, L., 2008, Uranium in surface waters and sediments affected by historical mining in the Denver West 1:100,000 quadrangle, Colorado: U.S. Geological Survey Scientific Investigations Report 2007-5246, 54 p.

\section{Other Information Sources Accessed for Bibliography}

American Geological Institute, 2010, GeoRef, accessed November 17, 2010, at http://www.csa.com/.

GeoScienceWorld, accessed November 17, 2010, at http://www.geoscienceworld.org/.

State of Colorado, 2010, Colorado State Publications Library Digital Repository, accessed November 17, 2010, at http://cospl.coalliance.org/fez/.

U.S. Geological Survey, 2010, Field Records Collection, accessed November 17, 2010, at http://www.cr.usgs.gov/ fieldrecords/.

U.S. Geological Survey, 2010, Mineral Resources Data System (MRDS), accessed November 17, 2010, at http://tin.er.usgs.gov/mrds/.

U.S. Geological Survey, 2010, National Water Information System (NWIS), accessed November 17, 2010, at http://waterdata.usgs.gov/nwis/. 
Publishing support provided by:

Denver Publishing Service Center

For more information concerning this publication, contact:

Center Director, USGS Crustal Geophysics and Geochemistry Science Center

Box 25046, Mail Stop 964

Denver, C0 80225

(303) 236-1312

Or visit the Crustal Geophysics and Geochemistry Science Center Web site at: http://crustal.usgs.gov/ 
